\title{
26. PALEOCENE, LATE OLIGOCENE AND POST-OLIGOCENE SILICOFLAGELLATES IN SOUTHWESTERN PACIFIC SEDIMENTS CORED ON DSDP LEG 21
}

\author{
Paulian Dumitrică, Geological Institute, Bucharest, Romania
}

\section{INTRODUCTION}

The first six of the eight DSDP Leg 21 sites yielded silicoflagellates in some intervals. Site data including the age of assemblages recorded in each of them are as follows:

Site 203: $22^{\circ} 09.22^{\prime} \mathrm{S}, 177^{\circ} 32.77^{\prime} \mathrm{W}$; water depth 2720 meters; Quaternary.

Site $204: 24^{\circ} 57.27^{\prime} \mathrm{S}, 174^{\circ} 06.69^{\prime} \mathrm{W}$; water depth 5354 meters; Recent with Maastrichtian reworking.

Site $205: 25^{\circ} 30.99^{\prime} \mathrm{S}, 177^{\circ} 53.95^{\prime} \mathrm{E}$; water depth 4320 meters; late Miocene.

Site 206 (with holes 206 and 206C): $32^{\circ} 00.75^{\prime} \mathrm{S}$, $165^{\circ} 27.15^{\prime} \mathrm{E}$; water depth 3196 meters; middle Eocene, late Oligocene, Miocene, Pliocene, Quaternary.

Hole 207A: $36^{\circ} 57.75^{\prime} \mathrm{S}, 165^{\circ} 26.06^{\prime} \mathrm{E}$; water depth 1389 meters; middle Eocene.

Site 208: $26^{\circ} 06.61^{\prime} \mathrm{S}, 161^{\circ} 13.27^{\prime} \mathrm{E}$; water depth 1545 meters; early Paleocene.

The late Oligocene to Quaternary silicoflagellates from Sites 203 through 206 and some species from the early Paleocene at Site 208 have been particularly investigated for this report. In addition, a few incertae sedis microfossils are included for their biostratigraphic value. No information is given on the middle Eocene silicoflagellates.

Most data discussed herein came from the investigations of core catcher samples prepared aboard the drilling vessel. Although the distance between such samples is about 9 meters, they gave sufficiently detailed information about the range of the taxa concerned in the thick late Oligocene-Pleistocene sequence. Since this sequence is almost continuously cored and yields fairly rich assemblages, the main purposes of this report are the biostratigraphic zonation of this interval and improvement of the zonation established by Martini (1971) for the equatorial Pacific sediments cored in Leg 7 of the DSDP. For these purposes, in addition to the Leg 21 core catcher samples, some from Site 66.1 (western Equatorial Pacific) and Site 33 (northeastern Pacific), kindly provided for radiolarian studies by the DSDP Sample Distribution Panel, have been investigated as well (Figures 1,2, and 3). The species determined previously from these two sites are not always similar to those determined by us, and for a better correlation, it was necessary that they should have the same content.

Particular attention was paid to some systematic questions since the successful use of the silicoflagellates in biostratigraphy depends in a great measure on the accurate determination of the taxa. Many of the opinions regarding these questions expressed herein are different from those of previous authors. This reflects the stage of present-day knowledge of the silicoflagellates, whereby the morphologic systematics is controlled by the temporal and spatial distribution of the taxa and is influenced by our phylogenetic constructions. In order to support some opinions, we made use of statistical data and of supplementary information obtained from the study of other silicoflagellate assemblages. Of course, some of the taxa used and some of the phylogenetic linneages proposed are controversial. Such controversies are inherent in any group, the systematics of which is in a state of flux. This is especially true of the silicoflagellates, where the wide variability sometimes raises very difficult problems.

\section{BIOSTRATIGRAPHIC ZONATION AND CORRELATION OF THE NEOGENE- QUATERNARY SILICOFLAGELLATES}

Although fairly recent studies based on land outcrops have emphasized the biostratigraphic value of the silicoflagellates, achievement of zonations for age determination and correlation of various assemblages represents one of the many results of the Deep Sea Drilling Project. The coring of long sequences bearing silicoflagellates provided an opportunity for determining the stratigraphic ranges of taxa and thus distinguished the most important changes with correlative value.

Martini (1971) established a zonation of the equatorial Pacific silicoflagellates for the first time. He distinguished the following four zones within the interval between the upper part of lower Miocene and Pleistocene: (a) Mesocena quadrangula Zone (upper Pliocene to Pleistocene), (b) Dictyocha fibula Zone (upper Miocene to lower Pliocene), (c) Dictyocha rhombica Zone (upper part of middle Miocene), and (d) Corbisema triacantha Zone (lower Miocene ? to lower part of middle Miocene). Ling (1970, 1972), Dumitricà (1972), and others also distinguished several assemblages with correlative value within the interval Miocene-Recent.

In Leg 21, Site 206 provided some of the most interesting data for correlation with the equatorial Pacific zonation and with other silicoflagellate sequences. Cooccurrence of the silicoflagellates with radiolarians, foraminifers, and nannoplankton offered a good opportunity for making fairly precise age determinations of the samples studied and for cross-correlation between the zonations based on these groups of microfossils.

The upper Oligocene and lower Miocene contain rather poor assemblages of silicoflagellates. The species of Naviculopsis, probably, will be the most adequate for this purpose-within this interval they are generally the most common species. This fact was recognized by Ling (1972) in the Mediterranean region (Italy) and Bachmann (1970a, 1971b) in Austria. Also, a good time-indicator seems to be Rocella gemma, whose first appearance was recorded in the 


\section{P. DUMITRICÃ}

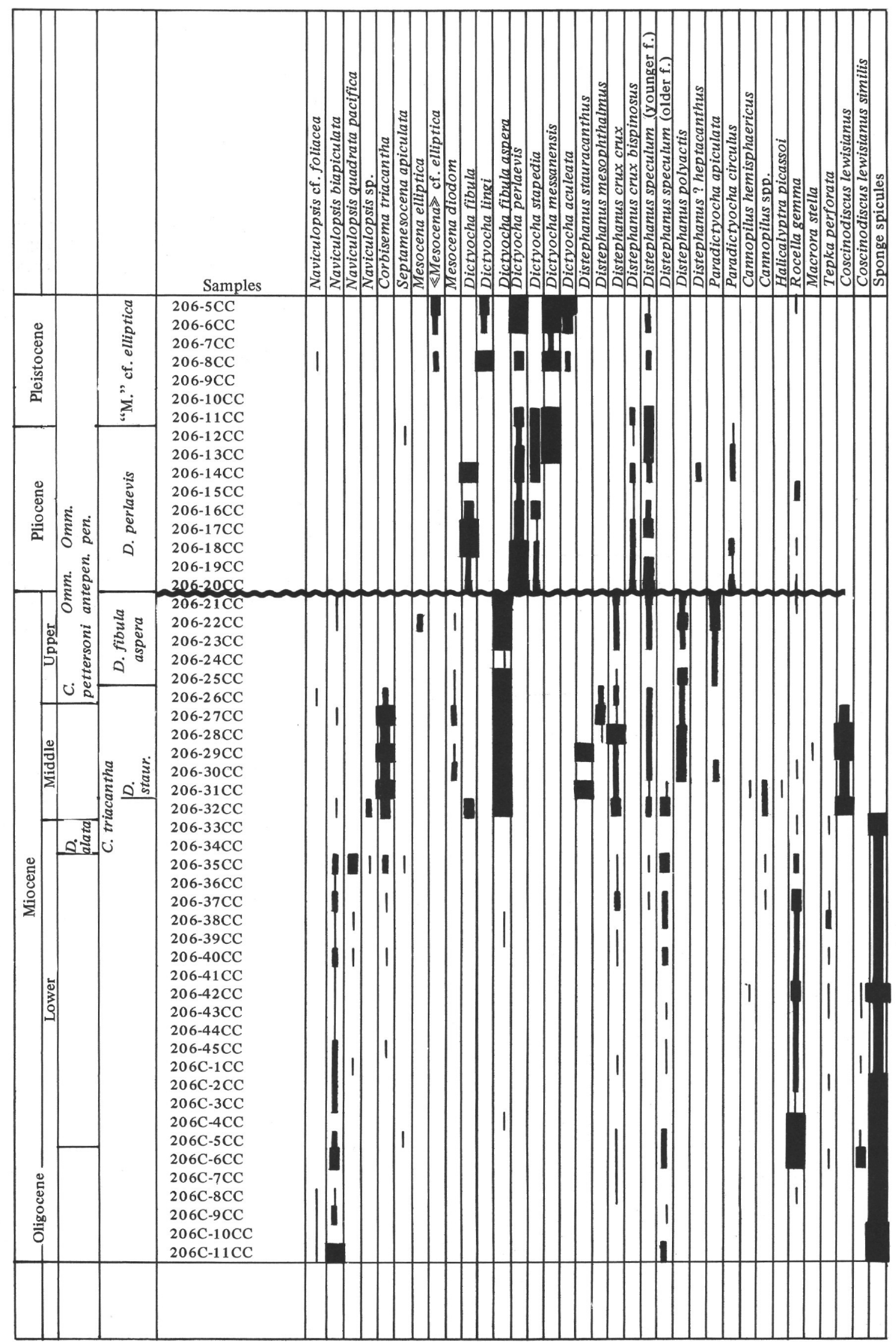

Figure 1. Distribution and zonation of silicoflagellates at Site 206. 


\begin{tabular}{|c|c|c|c|c|c|c|c|c|c|c|c|c|c|c|c|c|c|c|c|c|}
\hline & & & & & & & & & & & & & Таха & & & & & & & \\
\hline & 总 & 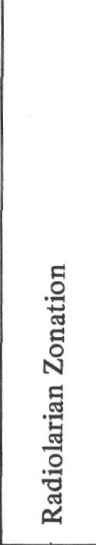 & 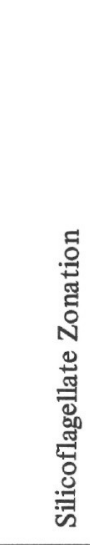 & & Sample & 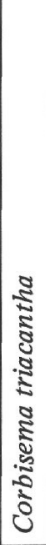 & 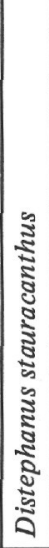 & 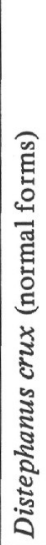 & 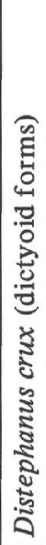 & 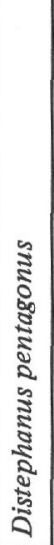 & 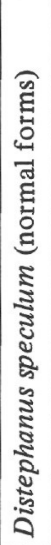 & 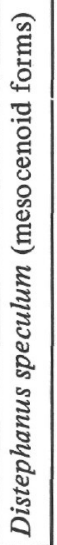 & 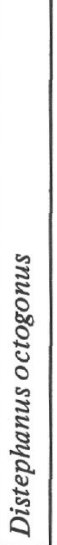 & 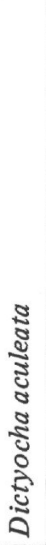 & 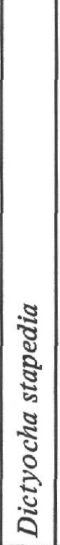 & 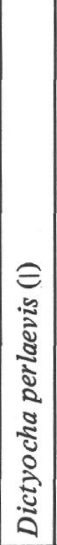 & 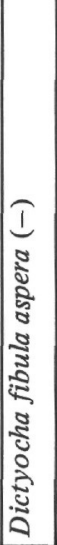 & 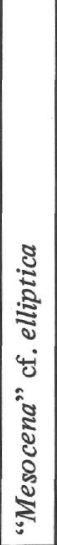 & 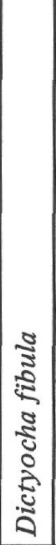 & 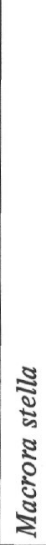 \\
\hline & & ह & & & $1-1,102-104 \mathrm{~cm}$ & & & & & & 1 & & & 18 & 36 & 19 & & 26 & & \\
\hline & 获 & 范 &. & & $1-2,100-102 \mathrm{~cm}$ & & & & & & + & & & 5 & 41 & 13 & & 40 & & \\
\hline & 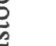 & 旁 & జี & & $1-3,118-120 \mathrm{~cm}$ & & & & & & + & & & 8 & 39 & 7 & & 46 & & \\
\hline & & $\begin{array}{c}5 \\
\vdots \\
1\end{array}$ & 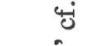 & & $1-4,77-79 \mathrm{~cm}$ & & & & & & + & & 1 & 10 & 36 & 13 & & 40 & & \\
\hline & & $\frac{2}{2}$ & $\dot{3}$ & & $2-1,75-77 \mathrm{~cm}$ & & & & & 1 & 2 & & & 1 & 54 & 28 & 1 & 13 & & \\
\hline & & $\begin{array}{l}\text { S. pen- } \\
\text { tas }\end{array}$ & & & $2-3,75-77 \mathrm{~cm}$ & & & & & + & 1 & & & 1 & 46 & 47 & + & 5 & & \\
\hline & & & & & $2-5,75-77 \mathrm{~cm}$ & & & & & & 14 & & & & 56 & 28 & 2 & & & \\
\hline$\ddot{\vec{B}}$ & & & ฐิ & & $3-1,85-87 \mathrm{~cm}$ & & & & & & 15 & 18 & & & 48 & 17 & 1 & & & \\
\hline & & & $\overline{\bar{\Xi}}$ & & $3-3,75-77 \mathrm{~cm}$ & & & & & & 28 & & & & 2 & 67 & 3 & & & \\
\hline & & $\tilde{\Sigma}$ & 2 & & $3-5,75-77 \mathrm{~cm}$ & & & & & & 24 & & & & 5 & 65 & 6 & & & \\
\hline & & בี & 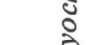 & & $4-1,90-91 \mathrm{~cm}$ & & & & & & 24 & 7 & & & 22 & 44 & 3 & & & \\
\hline & है & हై & $\tilde{E}$ & & $4-3,75-77 \mathrm{~cm}$ & & & 1 & & & 7 & 1 & & & 1 & 88 & 2 & & & \\
\hline & & కั้ & & & $4-5,75-77 \mathrm{~cm}$ & & & & & & 25 & & & & & 65 & 10 & & & \\
\hline & & $\Sigma$ & & & $5-1,75-77 \mathrm{~cm}$ & & & & & & 11 & & & & & 14 & 75 & & & \\
\hline & & 0 & ฉ్ & & $5-3,75-77 \mathrm{~cm}$ & & & & & & 11 & & & & & 10 & 78 & & 2 & \\
\hline & & & $\begin{array}{l}3 \\
8\end{array}$ & & $5-5,75-77 \mathrm{~cm}$ & & & & & & 4 & & & & & 4 & 91 & & & \\
\hline : & & & $\sqrt{3}$ & & $6-1,75-77 \mathrm{~cm}$ & & & + & & & & & & & & + & + & & & \\
\hline 邹 & & a. ह & 2 & & $6-3,75-77 \mathrm{~cm}$ & & & 2 & 4 & & & & & & & & 94 & & & \\
\hline & $\frac{0}{7}$ & ن : ฉั & & & $6-5,75-77 \mathrm{~cm}$ & & & & & & & & & & & + & + & & & \\
\hline & 帘 & & & & $7-1,75-77 \mathrm{~cm}$ & + & & + & & & & & & & & + & + & & & \\
\hline & & & & & $7-3,85-87 \mathrm{~cm}$ & & & & & & & & & & & + & + & & & \\
\hline & & 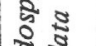 & : & $\ddot{\omega}$ & $7-5,75-77 \mathrm{~cm}$ & + & + & 1 & & & & & & & & + & 98 & & & 1 \\
\hline & & ซี ชี & वै. & 8 & $8-1,75-77 \mathrm{~cm}$ & + & & + & & & & & & & & + & + & & & \\
\hline & & & & & $8-3,57-77 \mathrm{~cm}$ & + & & 1 & & & & & & & & 45 & 54 & & & \\
\hline & & & & & $8-5,95-97 \mathrm{~cm}$ & & & & & & & & & & & + & + & & & \\
\hline
\end{tabular}

Figure 2. Distribution and zonation of silicoflagellates at Site 66. + is used for species recorded by Martini (1971) in the same section.

upper part of the Dorcadospyris ateuchus Zone (uppermost part of upper Oligocene) and whose highest frequency was recorded just above and below the Oligocene/Miocene boundary. Ling (1972) also reported the occurrence of this species at the same level, identified by him as the Rocella horizon.

A fairly good zonation and correlation of the silicoflagellate assemblages may be made at present for the middle Miocene-Recent interval. The zones distinguished are presented below.

\section{Corbisema triacantha Zone}

Martini (1971) defined this zone as having the lower boundary unknown and the upper boundary at the last occurrence of $\mathrm{C}$. triacantha. It is used in the present paper with the same definition.

In the equatorial Pacific sediments, the last occurrence of the species was recorded by Martini in the uppermost part of the Dorcadospyris alata Zone or lowest part of the Cannartus ? petterssoni Zone. It was noticed at 


\section{P. DUMITRICÀ}

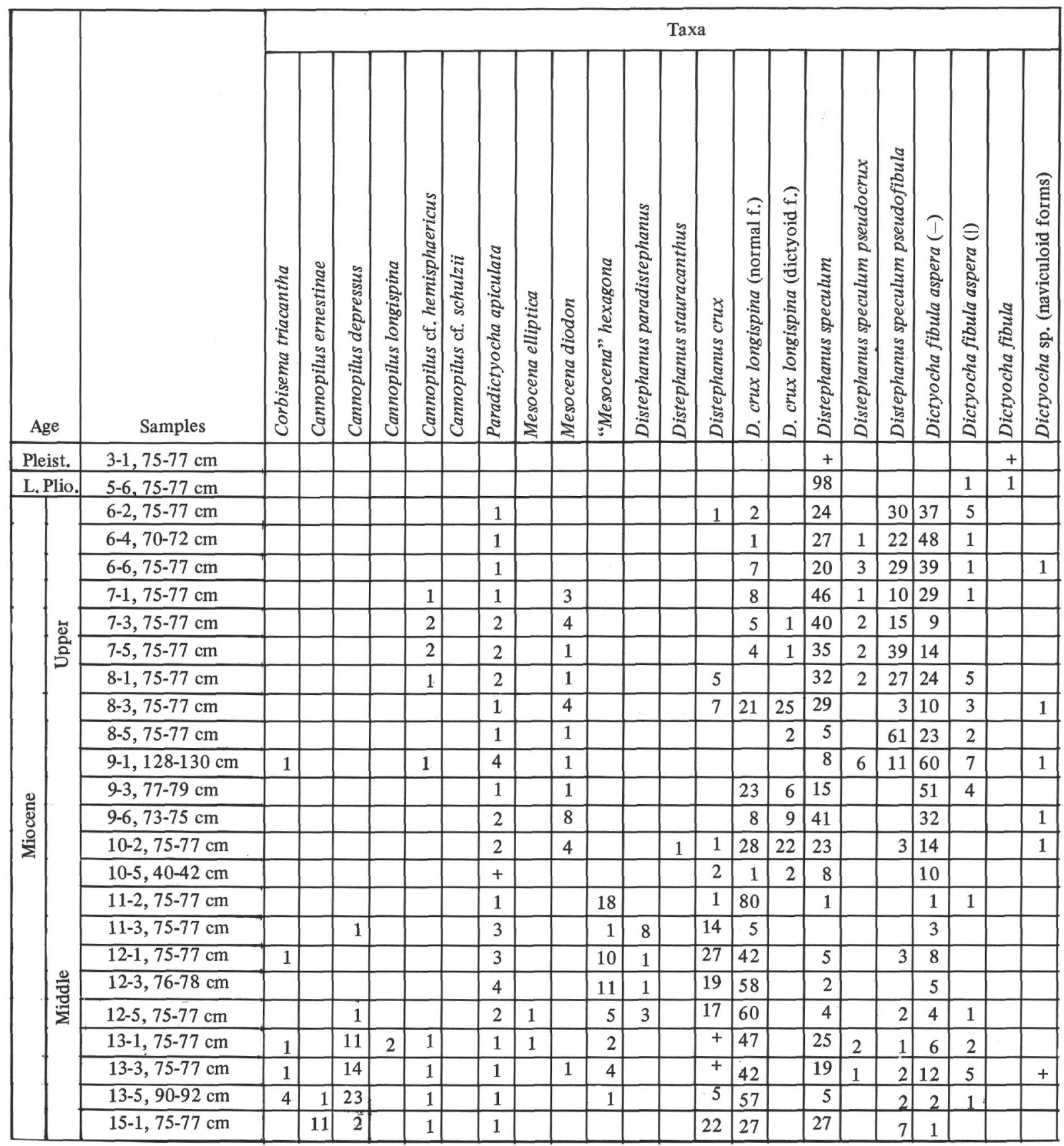

Figure 3. Distribution of silicoflagellates at DSDP Site 33.

approximately the same level at Site 206 (the base of $C$.? petterssoni Zone). However, it must be taken into account that at Site 206, the C. laticonus Zone is inserted between the $D$. alata Zone and the $C$. ? petterssoni Zone.

The Corbisema triacantha Zone may be subdivided into three subzones: (a) a lower subzone, below the first appearance of Distephanus stauracanthus, (b) a middle subzone, including the range of $D$. stauracanthus, and (c) an upper subzone with $D$. mesophthalmus.

\section{Lower Corbisema triacantha Subzone}

As discussed above, this subzone is defined as the lowest part of the $C$. triacantha Zone, below the first appearance of Distephanus stauracanthus. Its lower boundary is not yet established. The subzone has many species in common with the overlying subzone but lacks $D$. stauracanthus, $D$. polyactis, and $P$. apiculata. At Site 206, it is located in Sample 32, CC and in a few core catcher samples below. 


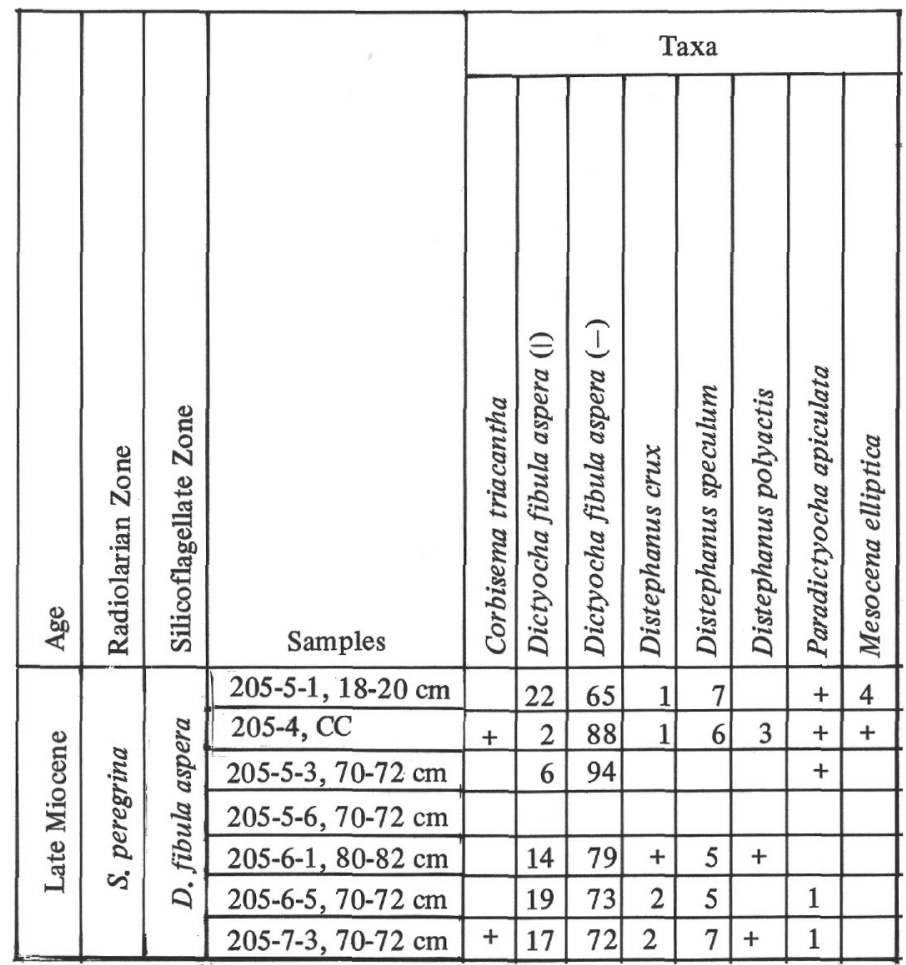

Figure 4. Distribution of silicoflagellates at Site 205. (I) and $(-)$ represent forms with apical bar in longitudinal and transverse position, respectively.

Typical assemblages of this subzone may be considered those described from Frättingsdorf, Austria by Bachmann et al. (1963) and from Szurdokpüspöki, Hazsnos, etc., by Hajós, (1968). This assemblage consists of $C$. triacantha, $S$. apiculata, D. fibula, D. fibula aspera, M. elliptica, D. crux, D. speculum, C. hemisphaericus, $C$. ex gr. depressus with five or six radial horns, $H$. picassoi, and Macrora stella.

\section{Distephanus stauracanthus Subzone}

This subzone is defined by the range of $D$. stauracanthus. Thus defined, the subzone is synonymous with the Dictyocha octacantha Horizon of Martini (1971) from the western equatorial Pacific, and with the Dictyocha fibula var. octagona assemblage of Ling (1972) recognized in the experimental Mohole drilling. In the western equatorial Pacific sediments cored on Leg 7 of the DSDP, the range of the species seems to be fairly short, but it is long enough in the eastern equatorial Pacific sediments cored in Leg 9, where it is almost equivalent to the Cannartus laticonus Zone. At Site 206, the situation is similar; the upper and lower boundaries of $D$. stauracanthus are within the $C$. laticonus Zone.

The last occurrence of Distephanus speculum (separated in the present paper as group $a$ ), and the first occurrences of Distephanus polyactis and Paradictyocha apiculata take place within this subzone at Site 206. The last species also makes its first appearance within this subzone in the experimental Mohole drilling.

The following three assemblages from land outcrops belong to the $D$. stauracanthus Subzone:
1) Nancoori deposits, Nicobar Islands, India. The silicoflagellates from these deposits have been illustrated by Ehrenberg (1854, pl. 36C) and Desikachary and Maheshwari (1956). They consist of Corbisema triacantha, $D$. fibula aspera, $M$. elliptica, D. crux, D. speculum, and $C$. hemisphaericus. Dictyocha siderea var. quadrata, illustrated by the last authors, is a phytolitharian, as Deflandre (1963) remarked.

2) Hollis Cliff, Virginia, U.S.A., illustrated by Ehrenberg (1854, pl. 33, no. XV) with the following species: $C$. triacantha, D. stauracanthus, D. crux, and M. diodon.

3) Radiolarian Schist Horizon, Romania, with localities Conita, Conele Mari, Rîmnicu Vîlcea district, and Slănic, Prahova district, mentioned by Loeblich et al. (1968). The silicoflagellate assemblage of this horizon was partly studied by Dumitricà $(1967,1968)$. It consists of: $C$. triacantha, $S$. spiculata, D. fibula aspera, $M$. elliptica, D. crux, D. stauracanthus, D. bachmanni, D. speculum, C. ex gr. depressus (forms with 5-7 but commonly 6 radial horns), $C$. tholus n. sp. (similar to $C$. iidaensis but commonly with 7-8 radial horns), $H$. ex gr. picassoi, $H$. miltiadei, $P$. apiculata, P. septenaria, and Macrora stella.

\section{Distephanus mesophthalmus Subzone}

This subzone is defined by the range of $D$. mesophthalmus. At Site 206, its upper boundary corresponds to the upper boundary of $C$. triacantha. This interval corresponds to the upper part of the Cannartus laticonus Zone and to the lower part of the $C$. ?petterssoni Zone of the radiolarian zonation. 
P. DUMITRICÁ

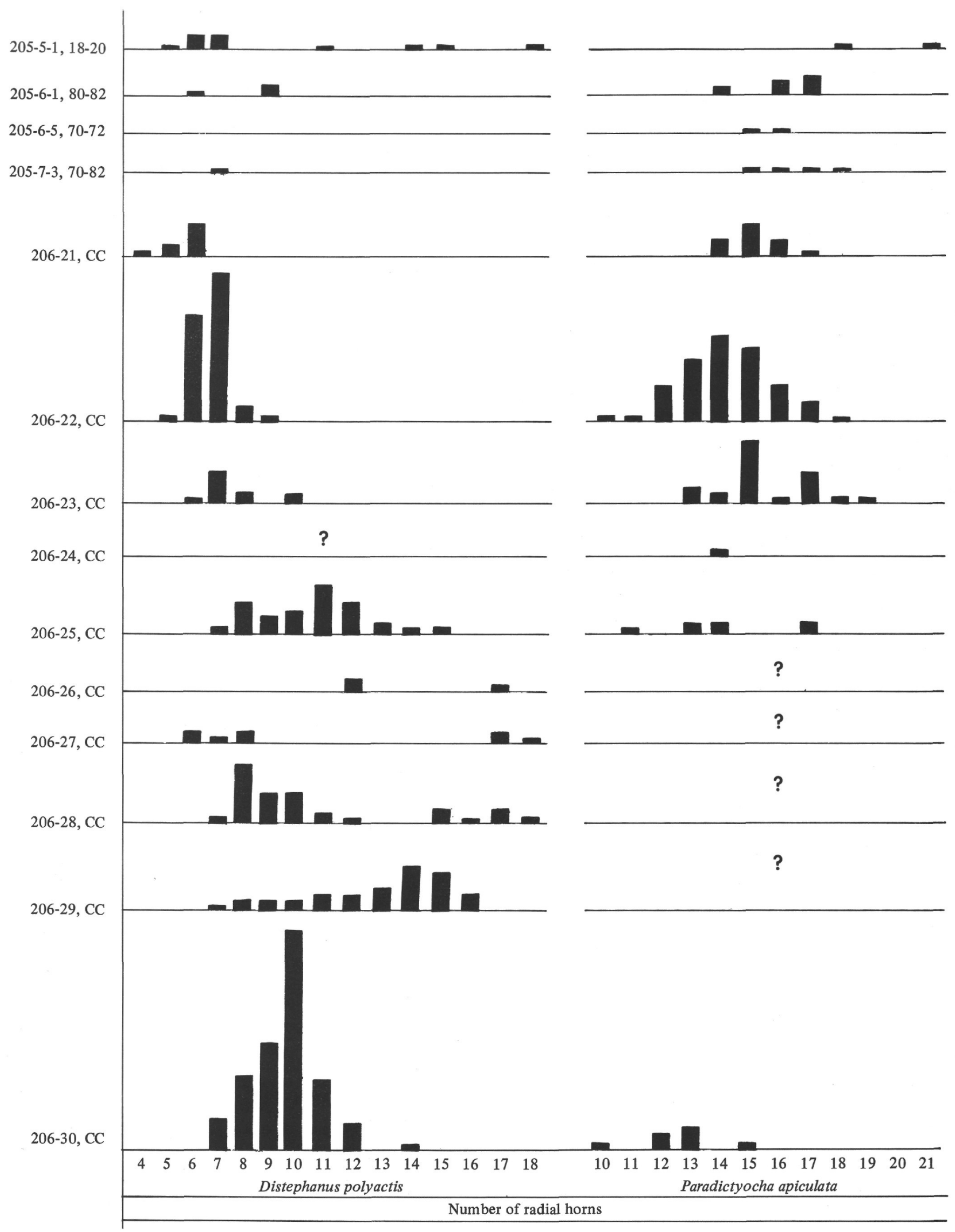

Figure 5. Diagrams of frequency of number of radial horns in Distephanus polydetis and Paradictyocha apiculata at Sites 205 and 206. 


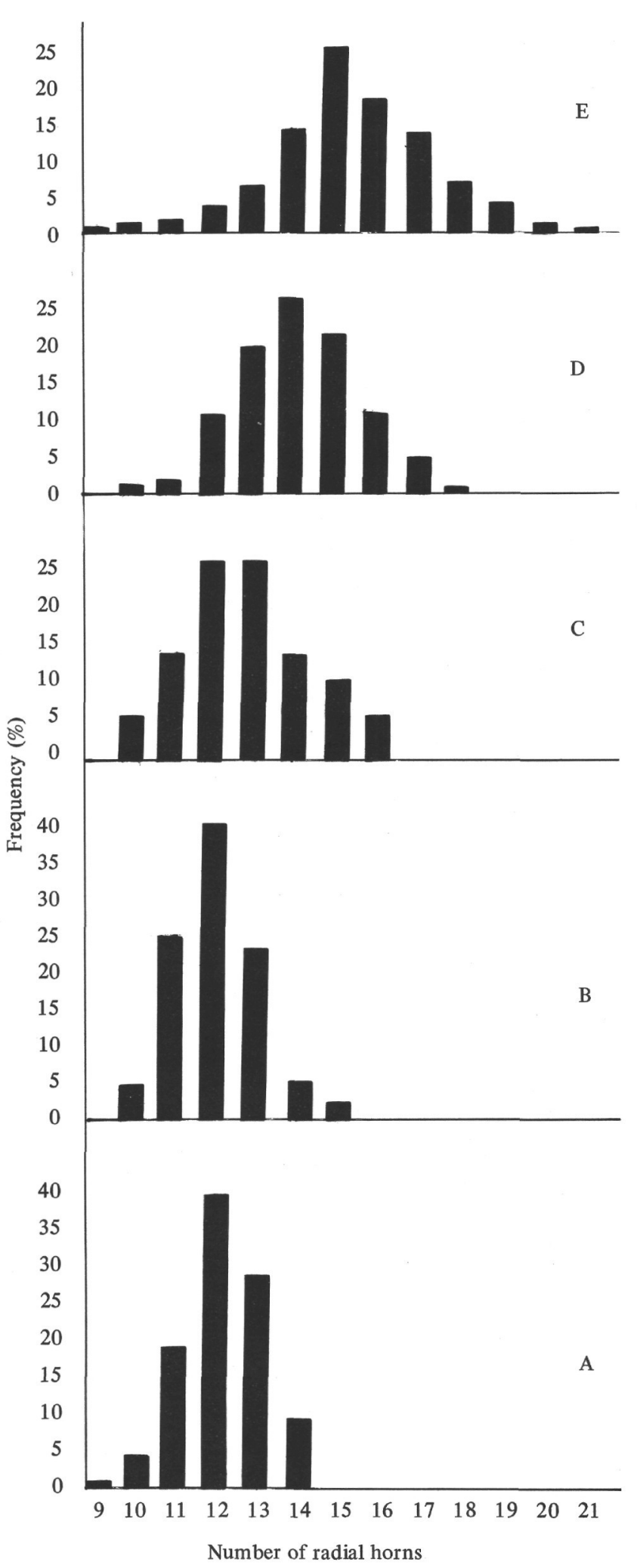

Figure 6. Comparative position of the population of Paradictyocha apiculata (D) in Sample 206-22, CC as against four other populations of the same species: A, B - Radiolarian Schist horizon (middle Miocene, D. stauracanthus Subzone), Ocnele Mari, Romania; C - middle Miocene ?, Hanyu, Sado Island, Prefecture Niigata, Japan; E - Lower Sarmatian (D. mesophthalmus Subzone), Folesti, Rimnicu Vilcea district, Romania.
As will be discussed below (see D. mesophthalmus in Systematic section), D. mesophthalmus is the result of a tendency for developing apical spines manifested in a species of the D. crux type during the upper part of the middle Miocene and probably the lower part of the upper Miocene. By this species, the subzone is correlative to the diatomites from Caltanisetta (Sicily, Italy), Oran (Algeria), and Nyermogy (Hungary).

D. mesophthalmus seems to be missing in many of the assemblages of this age. In these cases, Cannopilus depressus, with commonly seven or eight radial horns, Halicalyptra virginica, Distephanus crux longispina, or D. lemmermanni (new name for Dictyocha staurodon Lemmermann, 1901) may be used instead with fair reliability, at least at the present stage of knowledge of the stratigraphic distribution of the silicoflagellates.

The use of $C$. depressus ( - C. sphaericus) as a species with biostratigraphic value is based on its evolution remarked in some series. For example, the silicoflagellate assemblages from Frättingsdorf (Austria), the Radiolarian Schist Horizon (Romania), and the lower Sarmatian from Cârand (Romania) correspond to the three subzones of the $C$. triacantha Zone; the first being below the $D$. stauracanthus Subzone, the second being in this subzone, and the last being in the D. mesophthalmus Subzone. At Frättingsdorf, $C$. depressus is represented by forms with five or six radial horns; in the Radiolarian Schist Horizon by forms with five to seven, but commonly six radial horns; and in the lower Sarmatian by forms with six to nine, commonly seven or eight, radial horns. The last forms correspond to the type of Ehrenberg that have seven radial horns and cooccur with $H$. virginica at the type locality.

The same cooccurrence was remarked in the Spanish diatomites from Moron, Lucena, etc., in the Wakura Beds (Japan), and in the experimental Mohole drilling (Ling, 1972). All of these localities are probably of similar age. The D. stauracanthus Subzone is thus roughly synchronous with the Cannopilus sphaericus assemblages of Ling (1972).

In the western equatorial Pacific, the D. mesophthalmus Subzone is difficult to recognize, but it can be assumed to be in the interval between the last occurrence of $D$. stauracanthus and that of $C$. triacantha. It can easily be recognized at Site 33 in cores 12 to 15 and probably in the lower part of core 11 by the presence of C. triacantha and Cannopilus depressus commonly with seven radial horns. At this site, the upper part of the subzone is marked by the occurrence of Distephanus paradistephanus (Tsumura). The greater part of the occurrence of "Mesocena" hexagona lies in this subzone, but it is extended a little above, where its highest frequency was recorded (18\%). The single specimen of this species was recorded by Ling (1972) just above this subzone, and this finding is in agreement with its occurrence at Site 33.

The following may also be correlated among the assemblages described from land outcrops within this subzone:

1) The Wakura Beds (Japan) that among other species include Cannopilus depressus with six to nine radial horns, C. ernestinae and C. longispina present in Cores 13 and 15 at Site 33.

2) The lower Sarmatian assemblages from Romania (Cârand, Bremia, Folesti, Pâuusesti Otâ̂sâu, Bâile Covora), 
Hungary (Myermegy, etc.), Yugoslavia (Dolje and those described by Jerkovic, 1969), and the upper Badenian assemblage from Walbersdorf (Austria) described by Bachmann (1971a). All of these assemblages contain some of the following species: Cannopilus depressus, Distephanus mesophthalmus $=D$. macilentus, $D$. lemmermanni $=D$. staurodon sensu Lemmermann, and $D$. crux longispina.

\section{Dictyocha fibula aspera Zone}

This zone corresponds to the definition given by Martini (1971) to the D. rhombica Zone, representing the interval between the last appearance of $C$. triacantha and the base of $D$. perlaevis.

The D. perlaevis/D. fibula aspera datum plane is one of the most interesting events in the Neogene silicoflagellates. It is marked by the sharp change of the ratio between skeletons with a longitudinal apical bar and those with a transverse apical bar. This datum is very obvious in the equatorial sediments, and at Site 206, where these two species of Dictyocha are the most frequent taxa. Martini (1971) reported that it falls within the Ommatartus antepenultimus Zone of the radiolarian zonation and probably in the basal NN10 or within NN9 of the calcareous nannoplankton zonation.

At Site 206, this datum seems to correspond to the boundary $O$. antepenultimus/C. penultimus, but it is quite possible that the range of $O$. antepenultimus should have been longer; its upper part missing because of the discontinuity between $20, \mathrm{CC}$ and $21, \mathrm{CC}$, and thus this datum plane should also have fallen within the same zone.

At Site 206, the boundary between D. fibula aspera and $D$. perlaevis is also marked by the last occurrences of $D$. crux, $D$. polyactis, and $P$. apiculata.

The $D$. fibula aspera Zone may be correlated with the $D$. crux longispina and the $D$. speculum var. pseudofibula assemblages of Ling (1972) from the experimental Mohole drilling and with the interval recovered in Cores 6 to 10 and the upper half of Core 11 at Site 33.

\section{Dictyocha perlaevis Zone}

This zone is defined by the interval between the $D$. perlaevis/D. fibula aspera datum and the first occurrence of "Mesocena" cf. elliptica or D. aculeata, when the former is at a higher level. Thus defined, this zone is equal to the $D$. fibula Zone of Martini.

At Site 66, where there is a fairly good sequence for the interval middle Miocene to Pleistocene, the first occurrence of the nominal species is approximately synchronous with that of Dictyocha aculeata and is at about 2 to 3 meters below the base of the Quaternary established by means of Radiolaria. At Site 77 (Leg 9), the first appearance of Dictyocha mesocenoidea of authors (Hays et al., 1972, p. 79) (very likely " $M$ ". cf. elliptica) falls also at about 2 meters below the base of the Quaternary. Thus, the upper boundary of this zone may roughly be considered as being coincident with the Pliocene/Pleistocene boundary.

At Site 206, the lower boundary of this zone is marked by the first appearance of Dictyocha stapedia, Distephanus crux bispinosus, and Paradictyocha circulus. However, it must be noted that this synchronism may result from the disconformity between Samples 20, CC and 21, CC, so that a certain asynchronism as against this boundary must be supposed. For example, at Site $66, D$. stapedia makes its first appearance 2 or 3 meters above the boundary.

It must also be mentioned that the occurrence of Distephanus ? heptacanthus ( $=$ D. boliviensis) falls within this zone, and Dictyocha messanensis makes its appearance in the upper part of it.

The following two assemblages, very likely, belong to this zone:

1) Aegina, Greece, from which Ehrenberg (1854, pl. 19) illustrated Dictyocha perlaevis ( $=D$. fibula in his plate), Distephanus speculum $(=D$. aculeata $+D$. speculum $+D$. binoculus), Distephanus? heptacanthus and Paradictyocha circulus but no $D$. fibula with transverse apical bar.

2) Mejillones, Chile, from which Frenguelli (1940) illustrated $D$. speculum, $D$. perlaevis and $D$. heptacanthus $(=D$. boliviensis).

\section{"Mesocena" cf. elliptica Zone}

The lower boundary was briefly discussed above. As for the discordance between the various data concerning the first appearance of " $M$ ". cf. elliptica, the previous results have been summarized by Dumitricà (1972, Fig. 2). In that figure, the first appearance of this species is much higher than the Pliocene/Pleistocene boundary; its occurrence brackets the Jaramillo event. At Site 206, the occurrence of the species agrees with the cited scheme. In this circumstance, the lower boundary of the zone was established at the first appearance of $D$. aculeata because, thus, it is much closer to the boundary established in the equatorial Pacific.

The upper boundary is coincident with the last occurrence of " $M$ ". cf. elliptica. Neither at Site 206 nor at Site 66 could this boundary be established. At the former, this was because of the scarcity of silicoflagellates above 5 , $\mathrm{CC}$ and at the latter because of the lack of cores for the first 15 meters below the sea floor.

The data available from previous authors (see Dumitricà, 1972) provide reliable evidence concerning this question. The species became extinct a little below approximately the upper third of the Quaternary. Dictyocha lingi, and $D$. subarctios became extinct at this level as well.

\section{Dictyocha aculeata Zone}

This zone is defined as the interval above the last occurrence of "Mesocena" cf. elliptica. The living species, $D$. aculeata, D. messanensis, D. perlaevis, Distephanus speculum, $D$. octogonus and $D$. octangulatus, are about the only species occurring in this zone.

At Sites 66 and 206, this zone was not recorded. It is very distinct at Site 203, in the central north Pacific (Ling, 1970), in the Mediterranean Sea (Dumitricâ, 1972), in the experimental Mohole drilling (Ling, 1972), and in all Recent assemblages described by various authors.

\section{SILICOFLAGELLATES AT EACH SITE}

\section{Site 203}

A fairly poor assemblage, consisting of $D$. aculeata, $D$. messanensis and sometimes $D$. perlaevis with a low 
frequency, was recorded in Cores 1 and 2. They correspond to the D. aculeata Zone.

\section{Site 204}

The only silicoflagellates at this site have been recorded at the top of Core 1 in the Sample 204-1-1, 0-2 cm. The assemblage is very poor; one specimen of $D$. aculeata and one of $D$. messacanensis are the only forms found in situ. Beside them, a few reworked specimens of the Upper Cretaceous Lyramula furcula also have been encountered.

\section{Site 205}

Silicoflagellates have been recorded in the short interval 205-4, CC to 205-7-3, 70-72 cm of upper Miocene age. The silicoflagellates are common to few in most samples but are practically missing in the levels containing abundant volcanic glass. The distribution of the species at various levels are shown in Figure 4. Despite the presence of very rare $C$. triacantha, the assemblage seems to belong to the $D$. fibula aspera Zone and not the C. triacantha Zone.

\section{Site 206}

Two distinct silicoflagellate sequences have been recorded at this site: a late Oligocene-Pleistocene sequence almost continuously cored in Holes 206 and 206C, and a middle Eocene sequence in Hole 206C. Only the first one was studied for this report. This sequence offered the most important data for the biostratigraphic zonation and correlation established in the Neogene assemblages. Its importance is due not only to its continuity but also to its intermediate position between the equatorial and middle latitude silicoflagellate assemblages.

The range chart (Figure 1) shows that the distribution of the silicoflagellates is marked at this site by two disconformities. The most striking one was recorded between 20, CC and 21, CC. At this site, it coincides with the Miocene/Pliocene boundary established by means of the forminifers and nannoplankton. Accurate investigation of the latter proved that the disconformity is somewhere between $21-6,75 \mathrm{~cm}$ and $21-6,125 \mathrm{~cm}$. The disconformity is sharply marked by the extinction and first appearance of several species. More details may be seen in Figure 1. According to the silicoflagellates, the missing interval corresponds to a part of the upper Miocene. The second disconformity was noticed below $32, \mathrm{CC}$ and is due probably to increasing frequency of the sponge spicules.

\section{SYSTEMATICS}

\section{Genus LYRAMULA Hanna}

\section{Lyramula furcula Hanna}

(Plate 1, Figures 1-3)

Lyramula furcula Hanna, 1928, J. Pal., v. 1, p. 262, pl. 47, figs. 4-5, (fide Loeblich et al., 1968, p. 33, 125, pl. 26, figs. 1, 2); Deflandre, 1940 , p. 509, fig. 4; Deflandre, 1950, p. 61, figs. 163 , 165; Tsumura, 1963 , p. 29 , pl. 1 , fig. 1 ; pl. 3, figs. 1 , 2 ; pl. 16, figs. 1, 2; Gleser, 1966, p. 221, pl. 2, figs. 3, 3-7; Mandra, 1968, p. 256 , pl. 2, figs. 7, 8, 13; Ling, 1972, p. 171, pl. 27, figs. 16-18. Remarks: Isolated individuals of this species have been found reworked in the Recent sediments at Site 204 (Sample 104-1-1, 0-2 $\mathrm{cm}$ ) and in a few upper Oligocene and Neogene samples at Site 206.

Unreworked specimens have been encountered together with Vallacerta hortoni in Samples 31, CC and 32, CC (early Paleocene) at Site 208. Such a high occurrence of this species has also been reported by Gleser (1966).

\section{Genus CORBISEMA Hanna, emend Frenguelli}

Remarks: It must be recognized that present opinion concerning the content of this genus is not unanimous. The disagreement is due to the difficulty, at times, of distinguishing it from Dictyocha. This difficulty is, in turn, due both to the relativity of the criteria in use, and to the rather primitive state of our knowledge as to the evolution and phylogeny of the Cretaceous and Paleogene taxa.

In the present state of our knowledge, Corbisema includes species commonly characterized by the following elements: basal ring triangular consisting of hollow rods, the lumen of which is usually septate at corners; apical structure simple, without apical windows, sometimes with apical plate, sustaining spines directly connected to the lateral bars, most frequently being inserted at the junction of those bars to the basal ring.

The timerous character of the skeleton has a relative value. It is common to most species of Corbisema, distinguishing them from the species of other general, but the number of sides of the basal ring may vary from two (C. inermis disymmetrica) to four, five, or possibly more, according to various authors. In such cases, the assignments of species to this genus is supported by other morphological elements as, for example, the place of insertion of the sustaining spines and the septation of the lumen.

Frunguelli (1940) and Deflandre (1950) insisted particularly upon the position of the sustaining spines as a distinguishing character separating Corbisema and Dictyocha. In Corbisema, the sustaining spines are, by their origin, directly connected to the lateral bars, their place varying from the apical end of the lateral bars ( $C$. geometrica) to the basal end (most common case). Without diminishing the systematic value of this character, is may be remarked that the Quaternary species $D$. lingi possesses sustaining spines displaced on the lateral bars as in $C$. geometrica, and that some Neogene species of Dictyocha have sustaining spines situated either at the point of junction of the lateral bars to the basal ring or only displaced a very little on the latter. Such a displacement, however, is sometimes shown by the sustaining spines of some species of Corbisema (Corbisema cf. triacantha in Deflandre, 1950, figs. 114 and 115). On the other hand, this criterion has no applicability to the species lacking sustaining spines.

As for the inner septa described by Stradner (1961), it needs to be specified that they are missing in some species possessing almost all the other morphologic characters of the genus (C. flexuosa, etc.). Also, even the same species may have septa in some samples and not in others.

The existence of these deviations from the generic definition does not constitute an argument for rejection of the genus Corbisema or for its reduction to the type species, as Gleser (1966) did. In agreement with Frenguelli (1940) and Deflandre (1950) because of the extreme plasticity of the morphology of the silicoflagellates, any definition of species or genera has a relative value; the expressions "commonly", "usually", "ordinarily" usually must accompany them.

\section{Corbisema inermis (Lemmermann)} (Plate 12, Figures 7-9)

Dictyocha triacantha var. inermis Lemmeramnn, 1901, p. 259, pl. 10, fig. 21; Schulz, 1928, p. 249, figs. 30a-b, 75; Gemeinhardt, 1930, p. 43, fig. 33; Tsumura, 1963, pl. 8, fig. 17.

Dictyocha triacantha var. inermis f. inermis Gleser, 1966, p. 230, pl. 8 , figs. 1,$2 ;$ pl. 32 , fig. 1 .

Description: Basal ring commonly triangular, large, robust, with rounded corners, without radial spines or, rarely, with very small ones. Lateral bars much thinner than the basal bars, and usually conical, their diameter decreasing from the basal to the apical end. Sustaining spines absent or well developed and situated at the junction of the lateral bars with the basal ring or slightly displaced on the latter. They are not acute but cylindrical and truncate. The lumen of the skeleton is very narrow in both thin-barred specimens and in thick-barred ones. The three septa from the corners of the basal ring are generally well visible. Surface very rough, with characteristic ornamentation consisting particularly of minute crests 
or tubercles arranged in transverse rows. There is also an irregular ornamentation, especially in some very robust specimens, or even a reticulate one. The anomalies are numerous and may be manifested in deformation of the basal ring, increase in number of sustaining spines (Plate 11, Figure 8), appearance of supplementary lateral bars, or horns irregularly disposed on the lateral bars, etc.

Dimensions: Distance between two corners, 92 to $128 \mu$.

Remarks: This large species, which known according to Gleser (1966) from the Upper Cretaceous and Paleocene, was found only in the lower Paleocene sediments cored at Site 208 (interval 30, CC to $32, \mathrm{CC}$ ). Gleser (loc. cit.) remarked that the Paleocene specimens are the largest $(70-100 \mu)$ and most variable. Such features are also common to these Pacific forms. The latter are similar to $D$. triacantha var. inermis, illustrated by Schulz (1928, fig. 30 only), which has also a robust skeleton with rough surface and is lacking sustaining spines. From Schulz's figure 75 , as well as from Lemmermann's and others, they are distinguished by their truncate cylindrical sustaining spines and rough surface with transversely disposed ornamentation.

Recently Ling (1972) included $C$. inermis of authors in $C$. geometrica and thus extended the range of the latter from Late Cretaceous to Eocene. In our opinion, these two species are independent taxa. C. geometrica is characterized by the presence of the apical plate, whereas, $C$. inermis has no plate.

At Site 208,C. inermis disappears somewhere between 30, CC and 29, CC; its place being occupied by bipolar forms ascribed to $C$. inermis disymmetrica. Within the interval $30, \mathrm{CC}$ and $32, \mathrm{CC}$, and particularly in $31, \mathrm{CC}, C$. inermis is a frequent species among the radiolarians in the fraction larger than $68 \mu$.

\section{Corbisema inermis ssp. disymmetrica n. ssp.}

(Plate 12, Figures 1-6; Plate 13, Figures 1-8)

Dictyocha navicula Lemmermann, 1901, p. 257, pl. 10, fig. 11; Schulz, 1928, p. 243, fig. 16a (non 16b); Deflandre, 1932a, fig.

13; Tsumura, 1963, pl. 7, fig. 4; Gleser, 1966, p. 233, pl. 9, figs. 4,5 .

Corbisema apiculata f. naviculoidea Frenguelli, 1940, fig. 121.

Corbisema apiculata var. inermis Deflandre, 1950, figs. 87, 88.

Description: Skeleton robust with basal ring large, elliptical, without radial horns and constricted in the point of junction with the apical bar. The latter is arcuate and generally thinner than the basal ring. Sustaining spines absent or present, sometimes very long (Plate 12, Figure 6), with blund end. The lumen of the bars very narrow and interrupted by septa at the two rounded corners. Surface very rough, with ornamentation similar to $C$. inermis. Variability pronounced.

Dimensions: Length of basal ring, 79 to $122 \mu$; breadth in the middle part, 70 to $106 \mu$; maximum breadth, 95 to $115 \mu$.

Remarks: The bipolar dkeletons of $C$. inermis do not behave as simple naviculoid forms but as an independent taxon. At Site 208, its evolution can be followed from $31, \mathrm{CC}$ to $29, \mathrm{CC}$ by the increasing frequency shown below:

\begin{tabular}{lccc}
\hline \multicolumn{1}{c}{ Age } & Sample & $\begin{array}{c}\text { Triangular } \\
\text { Skeleton (\%) }\end{array}$ & $\begin{array}{c}\text { Bipolar } \\
\text { Skeleton (\%) }\end{array}$ \\
\hline Early mid Paleocene & 208-29, CC & 2 & 98 \\
Early Paleocene & 208-30, CC & 92 & 8 \\
Early Paleocene & 208-51, CC & 100 & 0 \\
\hline
\end{tabular}

The appearance of $C$. inermis disymmatrica seems to be a good correlative element. The subspecies is not known in Late Cretaceous nor, probably, in the lower part of early Paleocene. As D. navicula, it was reported in the Paleocene from Islands Morş and Fuur (Denmark) and in the Eocene from U.S.S.R. (Gleser, 1966). It is not synonymous with $N$. navicula as Gleser considered it to be. The latter was accurately described and illustrated by Deflandre (1950) and others and is quite different from $C$. inermis disymmetrica. The Pacific specimens are similar in shape to specimens illustrated by Tsumura (1963) and Gleser (1966) and are distinguished from those illustrated by Lemmermann (1901), Schulz (1928), and Frenguelli (1940), which are much longer.
This new subspecies is closely related to $C$. inermis inermis by its large size and superficial ornamentation. Specimens suggesting a transition from triangular forms have been found among the bipolar specimens in Sample 208-29, CC.

\section{Corbisema triacantha (Ehrenberg)}

(Plate 2, Figures 1-3)

Dictyocha triacantha Ehrenberg, 1844, p. 80 (fide Loeblich et al., 1968, p. 116).

Dictyocha triommata Ehrenberg, 1845, p. 56 (fide Loeblich et al., 1968, p. 119); Ehrenberg, 1854, pl. 33 (XV), fig. 11; Loeblich et al., 1968 , pl. 23, fig. 22 .

Dictyocha trigona var. langhiana Carnevale, 1908, p. 35, pl. 4, fig. 30.

Dictyocha irregularis Carnevale, 1908, p. 35, pl. 4, fig. 31 .

Dictyocha triacantha f. minor Desikachary and Maheshwari, 1956, p. 258 , text-fig. 2.

Corbisema trigona (part.) Tynan, 1957, p. 130, pl. 1, fig. 1.

Corbisema triacantha fa. minor Bachmann and Ichikawa, 1962 , pl. 2, figs. 22, 23; pl. 8, figs. 1, 2; Bachmann, Papp, and Stradner, 1963 , p. 151, pl. 17, fig. 28-35; Ling, 1972, p. 158, pl. 24, figs. 18, 19 (non figs. 20-23).

Dictyocha crux Bachmann in Ichikawa et al., 1964, p. 103, pl. 4, figs. 38,39 .

Dictyocha crux fa. trigona Bachmann in Ichikawa et al., 1967, p. 157 , pl. 4 , figs. $1-13$

Corbisema triacantha Dumitricà, 1968, pl. 2, fig. 10; Martini, 1971, pl. 1, fig. 1; Ling, 1972 , p. 156 , p1. 24 , figs. 11-13 only.

Corbisema langhiana Bachmann, 1970b, p. 8.

Remarks: Although Ehrenberg has not illustrated this species, the Miocene age of the deposits from which it has been described represents a sufficient argument to consider it as being synonymous with $D$. triommata Ehr., which is sufficiently well illustrated by its author.

The constant absence of the sustaining spines and septa are two distinctive characters of this species. It must not be confused with some Paleogene species as Ling (1972) did. He included both Eocene and Miocene forms under the name of $C$. triacantha (Ling, loc. cit., p1. 24, figs. 8-10). There is a morphological difference between them; whereas, the Eocene forms have sustaining spines and a small apical plate, the Miocene forms have neither sustaining spines nor apical plate. Their inclusion under the same specific name decreases the biostratigraphic value of this Miocene species.

C. triacantha is the last survivor of the genus. Its last occurrence was recorded in the upper part of the middle Miocene. In the miccle Miocene, where it is usually a common species, its frequency varies between 1 percent or less and 34 percent exceptionally, as for example in the middle Miocene of Rumania. At Site 206, its frequency was 7 to 26 percent.

\section{Genus NAVICULOPSIS Frenguelli \\ Naviculopsis quadrata ssp. pacifica n. ssp. (Plate 1, Figures 12-14)}

Description: Robust hollow skeleton with a large elongate basal ring, the lateral sides of which are convex, straight, or slightly concave at the point of junction with the apical bar. The latter is slightly curved, hollow, and as thick as the basal ring. The extremities of the ring are rounded and bear two opposite cylindrical horns with rounded ends.

Dimensions: Length of skeleton, 112 to $128 \mu$, of basal ring, 88 to $97 \mu$, of radial horns, 12 to $16 \mu$; breadth of basal ring, 35 to $43 \mu$.

Remarks: The most characteristic morphological elements of this subspecies are the cylindrical radial horns with rounded ends, which are not known in any species of Naviculopsis. Tsumura (1963, pl. 7, fig. 8) and Bachmann (1970a, text-figs. 3b, d, e) have illustrated some specimens of $N$. rectangularis with horns, which though somewhat similar, are shorter and more conical than cylindrical. They resemble the specimen illustrated in Plate 1, Figure 12 of the present paper, the only specimen of this type found in southwestern Pacific sediments cored in Leg 21. The basal ring of this subspecies is quite comparable with $N$. quadrata as illustrated by Bailey or $N$. rectangularis of most authors. 
At Site $206, N$. quadrata pacifica was found discontinuously between 206-35, CC and 206C-1, CC. The discontinuity of its occurrence is doubtless due to the scarcity of silicoflagellates in the early Miocene. The highest frequency was recorded in 206-35, CC, where it reaches about 35 percent.

Naviculopsis sp.

(Plate 1, Figure 15)

Remarks: Five specimens have been found at Site 206, four in 206-32, CC and one in 206-35, CC. They have a large elliptical basal ring with convex or nearly straight sides, armed at the corners with two acute horns. The bars of the skeleton are entirely hollow and generally thin, the apical bar being thinner than the basal bars. By their morphology these specimens somewhat resemble $N$. lata, but they show no remains of the lateral bars nor of a wider area at the junction between apical bar and the basal ring. $96 \mu$.

Dimensions: Length of shell, 110 to $120 \mu$, of basal ring, 81 to

\section{Naviculopsis biapiculata (Lemmerman) s. 1.}

(Plate 1, Figures 4, 5, 9, 10, ?7, ?8.)

Dictyocha navicula var. biapiculata Lemmermann, 1901, p. 258, pl. 10 , figs. 14,15 .

Naviculopsis biapiculata Ling, 1972, p. 181, pl. 30, figs. 1-4.

Naviculopsis constricta Ling, 1972, p. 183, pl. 30, figs. 5-8.

Remarks: Because of the difficulty of distinguishing $N$. apiculata from $N$. constricta, both are determined in the present paper as $N$. biapiculata s. 1 . The identification problem exists primarily because of the wide variability of the apical bar from narrow and hollow to wide and flat, and because of the few specimens recorded. The basal ring is either hollow in the median part or massive. Its shape also varies from elliptical (Plate 1, Figure 4) to elongate hexagonal, with lateral sides straight or slightly concave or convex.

At Site $206, N$. biapiculata was encountered almost uninterruptedly from late Oligocene to the boundary early/middle Miocene. Isolated individuals were also found in middle and late Miocene to the Miocene/Pliocene boundary. We do not believe that $N$. biapiculata is reworked at these high levels of the Miocene. Such a high occurrence of the species was also recently recorded in Mediterranean sediments (Dumitrica, 1972).

\section{Naviculopsis foliacea Deflandre}

(Plate 1, Figures 6, ?7)

Naviculopsis foliacea Deflandre, 1950, p. 76, figs. 235-240; Ling, 1972, p. 184, pl. 30, figs. 9-11.

Remarks: Isolated reworked specimens answering generally to the description and illustration of the species have been recorded at several levels of the Quaternary and Neogene sequence at Site 206 and more constantly in the late Oligocene. It is to be noted that no specimen shows a flattened hyaline area at the inner extremities of the basal ring as Deflandre (1950) remarked for the typical $N$. foliacea.

\section{Genus SEPTAMESOCENA Bachmann \\ Septamesocena apiculata (Schulz) (Plate 5, Figure 7)}

Mesocena polymorpha var. triangula Schulz, 1928, p. 237, figs. 3a-c; Gemeinhardt, 1930, p. 28, figs. 12a-b (non 12c=M. elliptica).

Mesocena oamaruensis var. apiculata Schulz, 1928, p. 240 , fig. 11. Mesocena apiculata Deflandre, 1932b, p. 499, figs. 34, 35; Tynan, 1957 , p. 134 , pl. 1, fig. 10 ; Stradner, 1961 , p. 89 , pl. 1, figs. 28 , 29, 32; Bachmann, Papp and Stradner, 1963, p. 152, pl. 19, figs. 60-62; Ichikawa, Fuji and Bachmann, 1964, p. 107, pl. 4, fig. 36; Bachmann and Pappe, 1968, pl. 3, figs. 1, 2; Bachmann, 1970a, p. 280 , pl. 5 , figs. $10-16$; pl. 6 , figs. $1-5$; Ling, 1972, p. 173 , pl. 28, figs. 2-4; Dumitrică, 1972, p. 905, pl. 3, fig. 2; non Hajós, 1968 , p. 67 , pl. 4, fig. 3 (=Corbisema triacantha, mesocenoid form)

Mesocena aff. apiculata Gleser, 1966, p. 283, pl. 29, fig. 9, ?pl. 28, fig. $5 ;$ ?pl. 33 , fig. 7 .
Septamesocena apiculata Bachmann, 1970b, p. 13; Bachmann, $1971 b$, p. 557, pl. 3, fig. 22; Ling, 1972, p. 193, pl. 29, figs. 11-15.

Remarks: S. apiculata is extremely rare in southwestern Pacific sediments. One specimen was found in Sample 106-12, CC (late Pliocene) and another one in Sample 206-35, CC (early Miocene). The first is probably reworked since no other record is known at such a high stratigraphic level.

In his last paper, Ling (1972) erroneously differentiated this species into two species, Mesocena apiculata (Schulz) and Septamesocena apiculata (Deflandre), by the absence of septal structure at the apices. He considered that the species Mesocena oamaruensis var. apiculata Schulz, taken by Deflandre (1932b) as the type for his Mesocena apiculata (Schulz), has no inner septa and, consequently, is a Mesocena, whereas, the specimens illustrated by Deflandre (loc. cit.) have septa and are included in Septamesocena. Ling based this division on his investigations undertaken on the Oamaru Diatomite. He writes that the "specimens from Oamaru which correspond with Schulz's original figure have no septa". We also investigated several samples from the Oamaru Diatomite provided by A. R. Edwards. In the sample coming from Cormacks (sample nr. S 136/888, col. A. R. Edwards and N. de B. Hornibrook, 1966), all the specimens of $M$. oamaruensis var apiculata Schulz have inner septa at the three apices.

Thus, the presence or absence of the inner septa must not be taken exclusively. In species with septate lumen there are sometimes specimens where septa are not clearly visible. This is the case not only with this species but also with many others we have noticed in the Paleocene, for example.

The most important feature of the species under discussion, a feature considered distinctive by Deflandre (loc. cit.), is the oblique direction of the small radial spines as against the plane of the basal ring. This feature is characteristic both for the specimens determined by Ling (loc. cit.) as Septamesocena apiculata and for those determined as Mesocena apiculata. However, there is actually a difference between the Paleogene and Miocene specimens of this species, as reported by Bachmann (1970a). He remarked that the Paleogene (Eocene and Oligocene) forms are rounded as a rule, whereas, the younger forms are generally more irregular, with the basal bars unequal and slightly convex or concave.

\section{Genus DICTYOCHA Ehrenbers}

\section{Dictyocha fibula Ehrenberg}

(Plate 2, Figures 14, 17; Plate 3, Figures 1-3; Plate 4, Figure 12; Plate 5, Figures 1-4)

Dictyocha fibula Ehrenberg, 1854, pl. 21, figs. 42a,b. Dictyocha fibula f. rhombica Schulz, 1928, p. 253, fig. 37; Ling, 1970 , p. 93 , pl. 18 , fig. 15 .

Dictyocha fibula var. brevispina Deflandre, 1932a, fig. 38.

Dictyocha brachyacantha Dumitricǎ, 1972, p. 906, pl. 6, figs. 3, 6; pl. 5, figs. 6,$7 ;$ pl. 7, figs. 1-3.

Remarks: The nomenclature of the wide variety of forms included by Ehrenberg and subsequent authors in D. fibula s. 1 . represents a very difficult problem. It is hoped that it will be generally solved by the restudy of Ehrenberg's original slides started by Sigurd Locker. In a letter dated 15 September 1971, he wrote that after his subsequent designation of the type locality (Oran), Dictyocha fibula Ehrenberg, 1840, only refers to specimens like Dictyocha fibula f. rhombica of Schulz. Under this name, Schulz included large specimens with rhombic basal ring, transverse apical bar, and short radial horns. Ehrenberg's specimens from Oran are also large and so is the specimen illustrated from this locality by Deflandre (1932a). Consequently, in the present paper we include in this species only the large forms with a transverse apical bar.

In southwestern Pacific sediments, they occur in the lower part of the middle Miocene and in most of the Pliocene. Their rea occurrence may probably be extended upwards to the Pleistocene because $D$. brachyacantha described from the Mediterranean late Miocene and Pleistocene seems to be a squarish variety of $D$. fibula. Generally, the large skeletons assigned here to $D$. fibula are separated from the smaller skeletons assigned to $D$. fibula aspera by the absence or scarcity of specimens of intermediate size and by other characters. For example, in Sample 106-32, CC, where the 
large skeletons of $D$. fibula cooccur with the small skeletons of $D$. fibula aspera, these two taxa may be fairly easily distinguished. The latter contains specimens with or without sustaining spines, with a transverse apical bar (32\%), and more rarely, with a longitudinal apical bar. $D$. fibula is represented by specimens with a tranverse apical bar short lateral bars, and rough surface but without sustaining spines (Plate 3, Figures 1, 3).

It seems, however, that distinction between large and small forms is more difficult in the lower part of the Miocene than in the upper part and in the Pliocene and Pleistocene.

At Site $106, D$. fibula is characterized by skeletons generally rhombic or squarish with strong superficial ornamentation and commonly without sustaining spines. A very interesting population of this species was recorded in the Sample 206-18, CC (Plate 2, Figures 14, 17; Plate 3, Figure 2; Plate 4, Figure 18; Plate 5, Figures $1-4)$. The assemblage of silicoflagellates is composed primarily of $D$. perlaevis $(46 \%)$ and large skeletons of $D$. fibula $(40 \%)$ with a transverse apical bar, with visible superficial ornamentation, and without sustaining spines. Beside the complete skeletons, there are a few $(3 \%)$ with apical apparatus more or less reduced (Plate 5, Figures 2-4) and with the basal ring rather similar in both shape and size except that it is generally more robust. Some of these reduced forms preserve one or two transverse lateral windows and even short remains of the apical bar (Plate 5, Figure 3) or only remnants of the lateral bars as inwardly directed spines (Plate 5, Figure 4). The remainder of the assemblage is occupied by completely mesocenoid forms (Plate 4, Figure 12; Plate 5, Figure 1). They are generally much more robust, but there is no difference in shape or size between them and the normal forms of $D$. fibula. Their superficial ornamentation is much stronger and represents a combination between a verrucose ornamentation, as in the Quaternary specimens of $D$. brachyacantha, and a reticulate ornamentation. By all of their morphology, such mesocenoid skeletons have been considered not as Mesocena but as mesocenoid forms of $D$. fibula.

Dimensions: Length of skeleton, 94 to $126 \mu$; length of basal ring, 80 to $107 \mu$; breadth of skeleton, 78 to $120 \mu$; breadth of basal ring, 67 to $103 \mu$.

\section{Dictyocha fibula ssp. aspera Lemmermann}

(Plate 2, Figures 4-13, 16, ?15)

Dictyocha fibula var. aspera Lemmermann, 1901, p. 260, p1. 10, figs. 27-28; Schulz, 1928, p. 233, fig. 36a, non 36b; Deflandre, 1950, fig. 26.

Dictyocha fibula f. rhombica Gemeinhardt, 1930, p. 50, fig. 40a-c; Desikachary and Maheshwari, 1956, p. 258, figs. 6, 8, 9, 15-18; Gleser, 1968 , p. 249 , pl. 15, figs. 4, 7, non 5, 9.

Dictyocha fibula cf. var. rhombica Bachmann, 1971b, p. 560, pl. 2, figs. 13-16.

Dictyosha rhombica Martini, 1971, pl. 1, figs. 8-10.

Dictyocha medusa Martini, 1971, pl. 1, fig. 3.

Dictyocha ausonia Deflandre, 1950 (pars), p. 67, figs. 194, 199-202; Ling, 1972, p. 159, pl. 25, figs. 1-10; Hajos, 1968, p. 65, pl. 3, figs. 11, 12; non Gleser, 1966, p. 252, pl. 9, fig. 1.

Dictyocha cf. aspera Dumitricà, 1972, p. 907, pl. 3, fig. 8, pl. 4, figs. $5-7,9 ;$ ? pl. 7, figs. $4-7$.

?Dictyocha sp. Ling, 1972, p. 164, pl. 26, figs. 4-8.

Dictyocha mutabilis Hajós, 1968, p. 66, pl. 3, figs. 13, 14.

Dictyocha fibula Bachmann and Ichikawa, 1962, p. 161, pl. 2, figs. 24-30, 32, 33, non 31; pl. 7, figs. 10-14; Bachmann in Ichikawa et al., 1964, p. 103, pl. 2, figs. 21-26; Bachmann in Ichikawa et al., 1967, p. 158, pl. 5, figs. 1-18; pl. 6, figs. 1-18; pl. 7, figs. 1-11.

Remarks: This taxon shows a wide infraspecific variability. One of the expressions of this variability is the change in position of the apical bar. Most previousauthors have separated as distinct taxa the forms with a longitudinal apical bar and those with a transverse apical bar. In order to solve this systematic question we have studied the double skeletons of this species from the Radiolarian Schist Horizon (middle Miocene) from Romania. In this horizon, most specimens of the species (80-93\%) have a transverse apical bar, 15 to 18 percent a longitudinal apical bar, and 1 to 4 percent have no apical bar. The four lateral bars are connected apically in a point or a squarish area. The frequency of the different types of double skeletons of the species reflects these percentages. The double skeletons with apical bars of both individuals in longitudinal position are most frequent; the double skeletons with an individual having a transverse apical bar and another having a longitudinal apical bar are much rarer; whereas, those with an individual having apical bar and another lacking an apical bar are only exceptionally found.

The double skeletons prove, therefore, that all the specimens with a longitudinal apical bar but with a basal ring similar to that of $D$. fibula aspera must be included in this taxon.

At Site 206, frequency of the forms with a longitudinal apical bar varies between 2 and 27 percent. A single exception was recorded in Sample 206-28, CC, where their frequency is about 67 percent.

The variability is also expressed in size and shape of the basal ring. The latter is generally characterized by rounded corners, constrictions at the junction with the lateral bars, radial spines short, and sustaining spines situated either at the point of junction of the lateral bars to the basal ring or a little displaced to the right. In some populations, specimens with longer radial horns may also exist.

The species must be distinguished from other Miocene species with a transverse or longitudinal bar; it has sustaining spines much displaced to the right on the basal ring, with basal ring squarish or rhombic consisting of straight or curved sides and armed with longer radial horns. Some of them are dictyochid forms of D. crux s.l. or of other species.

The youngest specimens of $D$. fibula aspera have been recorded in the late Miocene at Sites 203 and 206. It seems to be absent above the $D$. perlaevis/D. fibula aspera datum plane; the few specimens with a transverse apical bar occurring above this plane probably belong to $D$. perlaevis. Continuity of the species until the Pleistocene is, however, to be assumed because $D$. ling $i$, a Pleistocene species, seems by its morphology to be derived from $D$. fibula aspera. $50 \mu$.

Dimensions: Length of skeleton, 50 to $85 \mu$, of basal ring, 33 to

\section{Dictyocha lingi Dumitrica \\ (Plate 3, Figures 4-7)}

Dictyocha lingi Dumitricǎ, 1972, p. 306, pl. 8, figs. 1-7.

Remarks: Although the Pleistocene sequence cored at Site 206 contains some intervals lacking siliceous microfossiles, the evolution of this species could be followed rather clearly. The oldest occurrence of the species has been recorded in Sample 206-8, CC. About 24 percent of the assemblage of silicoflagellates of this sample consist of incipient and typical forms of $D$. lingi. The incipient forms (Plate 3, Figure 4) are generally smaller than the typical ones and have a rhombic basal ring with arcuate corners and constrictions at the junction with the lateral bars. The apical bar is transverse and shorter or equal to the lateral bars. The external sides of the basal ring bear a few small teeth on each segment comprised between the lateral bars and the radial horns. The sustaining spines are commonly situated at the base of the lateral bars and, rarely, slightly displaced on them. Such rhombic forms have also been found in the Pleistocene of the Mediterranean Sea, Site 128 of the DSDP and have been considered doubtfully as $D$. cf. aspera. At this site, their occurrence was limited only as the lowest level of the range of $D$. lingi $(128-11-3,148-150 \mathrm{~cm})$. At Site 206, the situation is similar. The incipient forms occur in addition to the typical forms only in the interval $8, \mathrm{CC}$ to $6, \mathrm{CC}$, being absent in $5, \mathrm{CC}$, where the typical forms reach a frequency of 6 percent.

Dimensions: Length of skeleton, 54 to $64 \mu$, breadth, 45 to $61 \mu$; length of basal ring, 38 to $31 \mu$; breadth, $35-47 \mu$.

\section{Dictyocha perlaevis Frenguelli}

(Plate 3, Figures 8-12; Plate 4, Figures 1, 2)

Dictyocha fibula Ehrenberg, 1854, pl. 19, fig. 45; Ling, 1970, p. 18, figs. 4-8; Martini, 1971 , pl. 1 , figs. $4,6,7$, non fig. $5=D$. aculeata; Ling, 1972, p. 160, pl. 25, figs. 11-15; Dumitricà, 1972 , p. 906 , pl. 3 , fig. 9 ; pl. 4 , fig. 8 ; pl. 5, figs. $2-5,8$; pl. 6 , figs. $1,2,4,5,7,8$.

Dictyocha perlaevis Frenguelli, 1951, p. 279, figs. 4b-c (fide Loeblich et al., 1968, p. 40, 109, p1. 51, figs. 7, 8). 
Remarks: The synonymy is prepared only for those forms with an apical bar in longitudinal position occurring from the base of the D. fibula Zone of Martini (1971) to the Recent.

The basal ring is commonly rhombic, with arcuate corners and constricted in the zone of junction with the lateral bars. The sustaining spines are either absent or, when present, are mostly disposed at the point of junction of the lateral bars with the basal ring or slightly displaced to the right. Their surface is either smooth or covered with visible superficial ornamentation.

Such forms are common in the sediments younger than the $D$. fibula/D. rhombica datum of Martini (loc. cit.). However, quite similar forms occur also in the $D$. rhombica and the $C$. triacantha zones of Martini but in a quantity generally less than 15 percent. Study of the double skeletons proved that they are D. fibula aspera with a longitudinal apical bar (see discussions on this taxon). We have not yet proven this by double skeletons, but it is very likely that some of the individuals with transverse apical bar occurring in the sediments younger than the $D$. perlaevis/D. fibula aspera datum should be simple forms of $D$. perlaevis. It must be remarked that other forms older that this datum plane and having a longitudinal apical bar are distinct species. Some of them are surely dictyoid forms of $D$. crux s. 1. They can be recognized by the resemblance between their basal ring and that of $D$. crux present in the same assemblage and by the sustaining spines being much displaced on the right.

Ehrenberg (1854) illustrated several species with a longitudinal apical bar. $D$. fibula is the most frequent among them. It may be seen with an apical bar in either a longitudinal or transverse position. Only one specimen of this species can be ascribed with certainty to $D$. perlaevis. It is the specimen illustrated from Aegina (Greece) (Ehrenberg, 1854, pl. 19, fig. 43). As was mentioned above, the sample from Aegina is situated in the $D$. perlaevis Zone. $D$. fibula and $D$. epiodon with a longitudinal apical bar, illustrated by Ehrenberg from Richmond (pl. 18, figs. 54, 55 of Ehrenberg, 1854 ), seem to be dictyoid forms of $D$. crux. In his plate, the apical ring of $D$. crux is sometimes very narrow (D. staurodon is such a form with its apical ring almost closed). It is normal that in such cases the forms with apical bars should be frequent.

$D$. perlaevis, described by Frenguelli from the Miocene strata from Mejillones, Chile, corresponds in all respects (morphology and stratigraphic level) to the forms here included to it. At Site 206, D. perlaevis was recorded between $20, \mathrm{CC}$ and $5, \mathrm{CC}$. $67 \mu$.

Dimensions: Length of skeleton, 44 to $96 \mu$, of basal ring, 32 to

\section{Dictyocha stapedia Haeckel}

(Plate 4, Figure 4; ? Plate 3, Figures 13-15; ? Plate 4, Figure 6)

Dictyocha stapedia Haeckel, 1887, p. 1561, pl. 101, figs. 10-12.

Dictyocha fibula var. stapedia Lemmermann, 1901, p. 261; Schulz, 1928, p. 254, fig. 39; Gemeinhardt, 1930, p. 35, fig. 42.

Dictyocha fibula Dumitricà, 1972, p. 906, pl. 3, fig. 7; pl. 5, fig. 1 .

Remarks: Dictyocha stapedia appears to be a good species or subspecies and not a simple variety of $D$. fibula. It must be mentioned that the apical spine characteristic of it was observed only in the specimens with an apical bar in longitudinal position. As in the present paper, $D$. fibula is considered as commonly having a transverse apical bar. $D$. stapedia is certainly related to $D$. perlaevis from which it is sometimes difficult to recognize by characters other than the apical spine. However, it is mostly smaller than $D$. perlaevis.

In the southwestern Pacific sediments, the species was recorded above the $D$. perlaevis $/ D$. fibula aspera datum plane. The same situation was noted at DSDP Site 66.1 (Figure 2), where its first appearance is in the upper Miocene.

\section{Dictyocha messanensis Haeckel}

(Plate 4, Figures 7, ?5, 6, 8; ? Plate 3, Figures 13-15)

Dictyocha fibula var. messanensis Ling, 1972, p. 161, pl. 25, figs. $18,19$.

Dictyocha messanensis Dumitricá, 1972, p. 907, pl. 8, figs. 8-13; pl. 9, figs. $2-4$.

Remarks: At Site 206, the occurrence of D. messanensis is limited to the Quaternary. The samples investigated seem to indicate that it comes from D. stapedia. Beginning with 206-13, CC, in some specimens of the latter, apart from the apical spine, accessory spines also appear on the lateral bars and sometimes on the basal ring (Plate 3, Figures 13-15; Plate 4, Figures 5, 6, 8). The basal ring is still elongate with arcuate corners and constrictions at the junction with the lateral bars as in $D$. stapedia. Forms with a squarish basal ring have been recorded only above $206-11, \mathrm{CC}$.

\section{Dictyocha aculeata Lemmermann} (Plate 4, Figures 9-11)

Dictyocha fibula Martini, 1971, pl. 1, fig. 3.

Dictyocha fibula var. aculeata Ling, 1972, p. 161, pl. 25, figs. 16, 17.

Dictyocha aculeata Dumitricà, 1972, p. 907, pl. 9, figs. 5-10.

Remarks: New data regarding the geologic range and evolution of the species have been obtained by investigation of samples coming from Sites 206 and 66. At the former site, the species appears to evolve from $D$. stapedia. As was shown above, within the interval 206-33, CC and 8, CC, the basal ring of this species may be sometimes armed with a few short additional spines. There is generally one additional spine of each segment of the basal ring limited by a radian horn and a lateral bar (Plate 3, Figures 13-15; Plate 4, Figure 6), never between the sustaining spines and the lateral bars. Only one specimen with additional spines situated in the last position was recorded in 206-11, CC, at the base of the Quaternary. At Site 206, this marks the oldest appearance of $D$. aculeata. It reaches a frequency of about 3 percent in $8, \mathrm{CC}$, increases to 11 percent in $6, \mathrm{CC}$, and to 43 percent in $5, \mathrm{CC}$.

Range of the species at Site 66 is fairly similar; the oldest occurrence of the species being recorded in the uppermost Pliocene.

\section{Dictyocha sp. (Plate 4, Figure 3)}

Remarks: A single specimen of this type was found in Quaternary Sample 206-5, CC. It cannot be included in any species hitherto described.

\section{Genus MESOCENA Ehrenberg}

Type species: Mesocena elliptica Ehrenberg, designated by Frenguelli, 1940, p. 69.

Remarks: The type species of this genus can be neither Mesocena ? octogona Ehrenberg, 1843, as stated by Loeblich et al. (1968), nor $M$. ? heptagona, for the reason that these specimens were included in the publication wherein Mesocena was validated by description. Both species were doubtfully included in this genus, and both are mesocenoid forms of Distephanus octogonus (Ehr.). Their designation as type species of Mesocena would entail many useless troubles.

Since some of the species of Mesocena s.1. have been assigned to Septemesocena, and others come from Distephanus and are to be assigned to Distephanus or to Paradictyocha, Mesocena appears to be limited to its type species. The question concerning the systematic value of Mesocena and its content needs further investigation. If it could be proven that some Mesocene simply represent reduced forms of various species, such forms have to be named generically as the complete species from which they come.

It is proved that some mesocenoid skeletons similar to $M$. elliptica are mesocenoid forms of Dictyocha. One of the most interesting cases was discussed in this paper under Dictyocha fibula.

It must also be mentioned that in the Pleistocene sediments of the Mediterranean Sea (Dumitrica, 1972) the so-called Mesocena elliptica verrucosa have a superficial ornamentation similar to that of some co-occurring large Dictyocha brachyacantha.

An interesting pecularity is shown also by the forms considered by Martini (1971) as Mesocena quadrangula. The specimens observed by us at DSDP Site 66.1 of Leg 7 have a verrucose surface and also often have four sustaining spines normal to the basal ring and located in the middle of the basal bars. That they are sustaining spines and not vestiges of the lateral bars is proven by the verrucose ornamentation which is best developed on the side opposite to these spines. By shape and size of their basal ring, by their superficial ornamentation and the presence of the sustaining spines, these Mesocena appear to be derived from Dictyocha with transverse 
apical bar. At Site 66.1, these "Mesocena" appear approximately at the level where these Dictyocha disappear.

Mesocena elliptica Ehrenberg, s.l.

(Plate 5, Figures 5, 6; Plate 6, Figure 1)

Remarks: In the southwestern Pacific sediments this much disputable species was not frequently recorded. Its occurrence was particularly limited to the upper Miocene at Site 205 and to the middle Miocene and upper Miocene at site 206. Two specimens were also found in the lower Miocene at this site (Sample 37, CC).

The middle Pleistocene specimens have been doubtfully included in this species. In the present paper they have been considered as "Mesocena" cf. elliptica (Plate 6, Figure 1).

\section{Mesocena diodon Ehrenberg}

(Plate 6, Figure 2)

Mesocena diodon Ehrenberg, 1844, p. 71, 84 (fide Loeblich et al., 1968, p. 54, 128); Ehrenberg, 1854, pl. 33, no. XV, fig. 18; Loeblich et al., 1968, pl. 27, fig. 4.

Mesocena crenulata var. diodon Lemmermann, 1901, p. 255, pl. 10, figs. 1, 2; Schulz, 1928, p. 236, fig. 1a-b; Gemeinhardt, 1930, p. 26, fig. 10a, non 10b; Deflandre, 1932a, fig. 4.

Mesocena elliptica diodon Dumitricà, 1972, p. 905 , pl. 1, fig. 3 .

Mesocena cf. elliptica Ling, 1972, p. 177, pl. 28, figs. 9-15 (part.).

Remarks: The fact that the forms armed with two polar horns generally occur independently from the four-horned forms, or at least outnumber them, and that their geologic range is much shorter than the latter, is, in our opinion, an argument in favor of considering them as an independent taxon of specific or subspecific rank. Most members of this taxon have a strong ornamentation consisting of transverse crests.

$M$. diodon was recorded only in the middle and upper Miocene at Site 206. Within the same interval, it was recorded by Ling (1972) in the experimental Mohole drilling, and by us at DSDP Site 33. Mandra (1968) reported a high frequency of the species $(75 \%)$ in the Valmote diatomite (Mohnian) and only one percent in the Buttle diatomite (Delmontian). Older or younger records of the species are very likely two-horned varieties of normally four-horned taxa.

\section{Genus DISTEPHANUS Stöhr}

Distephanus crux (Ehrenberg)

(Plate 6, Figures 4, 5, 8, 11)

Dictyocha crux Ehrenberg, 1840 (fide Loeblich et al., 1968, p. 85); Ehrenberg, 1854, p. 18, fig. 56; pl. 33 (XV), fig. 9.

Remarks: In southwestern Pacific sediments, D. crux was recorded in the middle Eocene at Sites 206C, 207A, and 208, in the late Oligocene and Miocene at Site 206, and in the late Miocene at Site 205. The Eocene forms were not particularly studied; only their presence was recorded. At Site 206, it was rarely found in the Oligocene and early Miocene. It is frequent in the middle Miocene, with a maximum of about 20 percent at 206-28, CC. It decreases again in the upper part of the middle Miocene and in late Miocene and disappears at the Miocene/Pliocene boundary. In the middle Miocene, the specimens are small, similar to D. crux fa. parva Bachmann.

In the post-Miocene sediments, it shows an interesting evolution. During almost all the Pliocene, there are only specimens with two apical spines, considered as $D$. crux bispinosus.

\section{Distephanus crux spp. bispinosus n. ssp. (Plate 6, Figures 3, 6, 7)}

Description: Basal ring as in D. crux; apical ring with two opposite spines situated along the longitudinal axis.

Dimensions: Length of skeleton with radial spines, 58 to $84 \mu$, of basal ring, 34 to $45 \mu$.

Remarks: Specimens certainly included within this subspecies have been recorded at Site 206 from the base of the Pliocene to the lower half of the late Pliocene. In the uppermost part of the Pliocene and base of the Pleistocene, before its extinction, the subspecies is represented only by very rare specimens with one apical spine in the longitudinal axis.

\section{Distephanus mesophthalmus (Ehrenberg)}

(Plate 6, Figures 9, 10, 12, 13)

Dictyocha mesophthalma Ehrenberg, 1844, p. 64, 80 (fide Loeblich et al., 1968, p. 39, 103); Ehrenberg, 1854, pl. 22, fig. 43; Loeblich et al., 1968, pl. 17, fig. 21.

Distephanus mesophthalmus Haeckel, 1887, p. 1563.

Distephanus crux var. mesophthalmus Lemmermann, 1901, p. 262, pl. 11, figs. 8-10; Schulz, 1928, p. 257, fig. 46.

Dictyocha cf. mesophthalma Deflandre, 1950, fig. 218.

Dictyocha schauinslandi Frenguelli, 1940, fig. 3.

Dictyocha macilenta Deflandre, 1950, p. 70, figs. 211-218.

Dictyocha crux f. parva (part.) Bachmann in Ichikawa et al., 1967, p. 156, pl. 4, figs. 16, 25-27.

Remarks: The basal ring is similar to that of $D$. crux. The apical ring is armed with two to four accessory spines. When there are only two accessory spines, the species cannot be confused with $D$. crux bispinosus since they are situated in the transverse axis, not in the longitudinal axis as in the latter.

The species might be considered as a simple variety of $C$. crux. However, some facts prove that it is an independent taxon of specific or at least subspecific rank. Thus, its occurrence is limited to the upper half of the middle Miocene and probably lower half of the late Miocene. The species was described from Caltanisetta (Sicily) and from Oran (Algeria). It is also frequent at some levels of the lower Sarmatian from western and central paratethys (Romania and Hungary), where the species is probably best developed and contains forms with long apical spines, a large apical ring, and a basal ring with straight or concave sides, known as Distephanus macilentus (Defl.).

Within the Pacific area, the species is known from the lida Diatomite, where among specimens of $D$. crux f. parva lacking apical spines, Bachmann (1967) has illustrated forms with two to four apical accessory spines. Here the species seems to behave as $D$. crux, characterized by a tendency to develop apical spines. It must be noted that the same is the case in the lower Sarmatian where the species is connected to $D$. crux s.l. by a complete series of intermediate forms.

In the southwestern Pacific D. mesophthalmus was found in the upper half of the middle Miocene between 206-26, CC and 206-28, CC. Its frequency is low in these two extreme samples but reaches 26 percent in the middle part of the interval $(206-27, \mathrm{CC})$.

\section{Distephanus stauracanthus (Ehrenberg)} (Plate 6, Figures 14, 15)

Dictyocha stauracanthus Ehrenberg, 1845, p. 56, 57, 76 (fide Loeblich et al., 1968, p. 43, 115); Ehrenberg, 1854, pl. 33 (XIV), fig. 5; pl. 33 (XV), fig. 10; Loeblich et al., 1968, pl. 24, figs. 11, 12 .

Dictyocha stauracantha Dumitricǎ, 1967, pl. 2, figs. 2-13; Dumitricà, 1968, pl. 2, fig. 11.

Distephanus crux var. octacanthus Desikachary and Maheshwari, 1956 , p. 260, text-figs. 10,12, 13; Leoblich et al., 1968, p. 120 , pl. 24, figs. 25-27; Ling, 1972, p. 166, pl. 217, figs. 20-22.

Dictyocha octacantha Martini, 1971, p. 1697, pl. 1, fig. 16.

Dictyocha fibula var. octagona Tsumura, 1963, p. 55, pl. 2, fig. 4; pl. 10, figs. 11-13; pl. 23, figs. 8-10; Loeblich et al., 1968, p. 37, 95, pl. 13, figs. 5-8; Ling, 1972, p. 161, pl. 26, figs. $1,2$.

Doctyocha octagona Martini, 1971, pl. 1, fig. 15.

Not Distephanus stauracanthus Gleser, 1966, p. 263, p1. 19, fig. 10.

Remarks: The above synonymy prepared for this species emphasizes the differences between the opinions of previous authors and ours. There is a tendency not to synonymize $D$. octacanthus with $D$. stauracanthus. This tendency is noticed in both Martini (1971) and Ling $(1970,1972)$. The latter author considers that these species should be regarded as separate taxa. He bases his opinion on the fact that Ehrenberg's figures do not possess two longer radial spines, whereas, $D$. octacanthus does. He therefore identifies $D$. staurachanthus with a Quaternary species which, though similar, is distinguished from it by having equal and very short radial spines (Long, 1970). The latter is, in our opinion, a form better related to D. octangulatus Wailes, with which it was found to cooccur, than to D. stauracanthus. Ehrenberg described his species from Hollis Cliff, Virginia, and Norwich, Connecticut. The former is considered as 
Helvetian by Loeblich et al. (1968), but its silicoflagellate assemblage, illustrated by Ehrenberg (1854, pl. 33 (XV)), may be very easily compared with the interval of occurrence of $D$. stauracanthus at Site 206. Ehrenberg's figures show a longer radial spine, the second being probably broken. Thus, the species Desikachary and Maheshwari described as D. crux var. octacanthus and coming also from the Miocene is, in our opinion, synonymous with Ehrenberg's species. In the middle Miocene deposits of Romania (see below) among forms with long axial radial spines, there are also forms with much shorter axial spines, and all these forms are developed within the field of variability of the species.

The previous authors have differentiated Distephanus octacanthus or D. crux var. octacanthus from Dictyocha octagona or D. fibula var. octagona. In our opinion $D$. fibula var. octagona Tsumura is nothing but a fibuloid form of $D$. stauracanthus. In the experimental Mohole drilling section (Ling, 1972, text-fig. 4), their occurrences are superposed. A similar situation was found at Site 206. The cause of these different opinions is likely due to the fact that the previous authors have studied only marine sediments where the species is generally sparse and characterized by very slight variability, except for the two forms. An adequate deposit for the study of this species is the Radiolarian Schist Horizon (middle Miocene, the Cannartus laticonus Zone) from Romania, where the species sometimes reach a frequency of up to 60 percent. The variability of the species is significant in this horizon, and among other variants there are also specimens with an apical bar. They are very rare, generally under one percent. In the Pacific sediments, the dictyoid forms seem to be much more stabilized because their frequency is higher, sometimes outnumbering the normal forms of D. stauracanthus.

As noted by Martini (1971), the species is short ranging, its occurrence being recorded as a horizon in the upper part of the Corbisema triacantha Zone, which would correspond to the middle part of the Dorcadospyris alata Zone. At Site 206, D. stauracanthus has been recorded in the Cannartus laticonus Zone, interval 29, CC to $31, \mathrm{CC}$, which is wholly comparable with its occurrence in the equatorial Pacific sediments cored during Leg 9 of the DSDP (Hays et al., 1972, Biostratigraphic charts). In samples 206-29, CC and 31 , $\mathrm{CC}$, the species is represented only by specimens with an apical ring, whereas, in Sample 30, CC there are both forms with an apical ring $(5 \%)$ and with an apical bar $(2 \%)$.

\section{Distephanus speculum (Ehrenberg) s.l. (Plate 7, Figures 1-9, 11)}

Remarks: This species, as it is understood at present, exhibits a wide variability in size, number of radial horns, of apical windows, presence or absence of sustaining and apical spines, and number of apical spines (two or as many as the apical bars. Two distinct groups could be recognized during the investigation of the core catcher samples at Site 206.

1) A group represented by forms without apical spines, with a large apical ring, and a basal ring generally lacking sustaining spines and with straight bars (Plate 7, Figures 1-4). The hexagonal forms are common except for 206-11, CC, where the pentagonal forms (Plate 7, Figure 1) outnumber (16\%) the hexagonal forms $(2 \%)$. The occurrence of the specimens of this group was recorded from late Oligocene to middle Miocene $(206-31, \mathrm{CC})$. By its characters, this group seems to have generated $D$. polyactis, the appearance of which takes place at the disappearance of $D$. speculum of this type.

2) The second group is younger. At Site 206, its appearance was recorded in the upper part of early Miocene $(206-37$, CC). It is characterized by the presence of apical spines in some forms, by an apical ring generally smaller than in the first group, and by a basal ring with various curvatures (convex or concave) (Plate 7, Figures $3-9,11$ )

\section{Distephanus polyactis (Ehrenberg)}

(Plate 7, Figures 10, 12, 13; Plate 8, Figures 1-10; Plate 9, Figures 1, 2)

Dictyocha polyactis Ehrenberg, 1839, p. 129, table (fide Loeblich et al., 1968, p. 40, 109); Ehrenberg, 1854, pl. 22, fig. 50; Loeblich et al., 1968, pl. 19, fig. 9.
Distephanus speculum var. polyactis Lemmermann, 1901, p. 265, pl. 11, fig. 17; Zanon, 1934, p. 34, figs. 47, 48.

Distephanus polyactis Deflandre, 1932b, p. 501, fig. 40 .

Distephanus speculum var. septenarius (part.), Gemeinhardt, 1930, p. 69 , fig. $58 \mathrm{~d}$, non $58 \mathrm{a}-\mathrm{c}$.

Distephanus speculum var. octonarius (part.) Gemeinhardt, 1930, p. 69 , fig. 59 c, non $59 \mathrm{a}$, b.

Distephanus octonarius var. polyactis Gleser, 1966, p. 273, pl. 21, figs. 7-8.

Paradictyocha polyactis f. completa Frenguelli, 1940, figs. 7f, 8a.

Paradictyocha polyactis f. polyactis Gleser, 1966, p. 277, pl. 24, fig. 7-11.

Paradictyocha polyactis Ling, 1972, p. 190, pl. 51, figs. 9-11.

Remarks: Deflandre (1932b) and Frenguelli (1940) established the opinion that Dictyocha polyactis of Ehrenberg and Mosecena crenulata var. spiculata of Lemmermann represent (the former the complete form) the latter a mesocenoid form of one and the same species, Dictyocha polyactis $=$ Distephanus polyactis $=$ Paradic tyocha polyactis. In the present state of knowledge concerning the category of species in silicoflagellates, and the stratigraphic range and evolution of silicoflagellates, this point of view seems erroneous.

The two so-called forms are mostly found independently in sediments and do not behave as forms of a species. Deflandre himself recognized this fact but he considered carefully that both forms might belong to the same species, the mesocenoid forms being a result of a rapid rate of multiplication, as really happens in the Recent Distephanus octogonus (Ehr.). Recently, Ling (1972) also considered that the complete forms should be specifically separated from the mesocenoid forms.

At Sites 205 and 206, the two taxa occur either together or independently, but their occurrence is embraced within the same interval (206-30, CC to 206-21, CC). Such a synchronous occurrence would support Deflandre's opinion. It is however contradicted by other facts.

In Figure 5 are presented diagrams of the frequency of the number of radial horns for D. polyactis and $P$. apiculata at Sites 206 and 205. Unfortunately the number of specimens was not always sufficient to draw incontestable conclusions in all cases. However, these data, together with supplementary data obtained by investigations carried out on samples from Japan, Italy, Spain, and Romania, showed that whereas the number of radial horns in $P$. apiculata varies between 10 and 20 or more (most frequently between 11 to 17, with maxima for the forms with 12 to 15 radial horns) in $D$. polyactis the number of radial horns varies within other limits.

In Sample 206-30, CC, where the number of specimens was sufficient for a statistic calculation, the field of variation is limited between the forms with 7 and 14 radial horns, the maximum value being recorded for the variety with 10 radial horns. The diagram is normal and denotes a homogeneous population. A similar curve seems to define the populations from the Mediterranean Miocene: Caltanisetta, Grotte and others in Italy, and Moron, Lucena in Spain (the specimens illustrated by several authors appear to suggest this, having 7 to 13 radial horns).

Gleser (1966) has found 9 to 11 radial horns in her Distephanus octonarius var. Polyactis and 10 to 14 in Paradictyocha polyactis $\mathrm{f}$. polyactis. Both are conspecific and have been reported by Gleser from the Neogene of Sakhalin and Kamchatka. Gleser's affirmation that the latter differs from Distephanus by a wavy apical ring and sustaining spines located under the lateral bars does not appear to be true.

The homogeneity of the species demonstrated in $206-30, \mathrm{CC}$ is more or less destroyed in the upper levels of the column, for example, between 206-29, CC and 25, CC. It is also interesting that, beginning at 206-23, CC, there occurs a morphological involution of the species, the number of radial horns decreases gradually from 6 to 10 in $23, \mathrm{CC}$, to 5 to 9 in $22, \mathrm{CC}$, and to 4 to 6 in $21, \mathrm{CC}$. This phenomenon appears like a return to the number of radial horns of the ancestral species. That the specimens with four radial horns are not $D$. crux and those with six radial horns are not $D$. ex gr. speculum is demonstrated by their size, absence of sustaining spines, very emphasized superficial ornamentation, etc. A similar disintegration of the species was remarked in the upper Miocene at Site 205 (see Figure 5).

Dimensions: Diameter or maximum length, when the skeleton is elongated, 52 to $124 \mu$. 
Stratigraphic range: At Site 206, the species was found in the middle and late Miocene, and in late Miocene at Site 205. Within the same interval seem to be included its occurrences in Italy, Spain, western Pacific area (Japan, Kamchatka, Sakhalin) and eastern Pacific (experimental Mohole drilling).

Phylogeny: $D$. polyactis very probably comes from $D$. speculum group $a$, described above, whose occurrence at Site 206 stops at the appearance of $D$. polyactis.

\section{Distephanus? heptacanthus (Ehrenberg)}

(Plate 10, Figures 1-4, 7; Plate 11, Figure 6)

Dictyocha heptacanthus Ehrenberg, 1840, p. 208 (fide Loeblish et al., 1968, p. 38, 100); Ehrenberg, 1854, pl. 19, fig. 39; Loeblish et al., 1968 , pl. 17, fig. 10 .

Dictyocha boliviensis Frenguelli, 1940, p. 44, fig. 4a-d; Loeblich et al., 1968, p. 84, pl. 9, figs. 3-6.

Dictyocha boliviensis var. major Frenguelli, 1951 (fide Loeblich et al., 1968 , p. 34, 84, pl. 51, figs. 4-6)

Description: Shell large, consisting of a hexagonal or heptagonal basal ring armed with six to seven radial horns. Apical apparatus small, conical, high, constituted of three to six unequal apical windows, with or without an apical spine, and connected to the basal ring by six to sevel long lateral bars. Normally without sustaining spines. Surface of skeleton rough with visible superficial ornamentation.

Dimensions: Diameter of skeleton, 70 to $87 \mu$, or basal ring, 54 to $63 \mu$.

Remarks: The species was recorded only in the late Pliocene Sample 206-14, CC, where its frequency reach a value of 7 percent. The forms with six radial horns are more frequent than those with seven. A single specimen (Plate 10, Figure 3) lacking radial horns was observed.

Dictyocha boliviensis is certainly a junior synonym of $D$. heptacanthus. All the morphological characters, number of radial horns, number of apical horns, number of apical windows, absence of sustaining spines, size of apical apparatus and basal ring, are in agreement with this synonymy.

The geological range of the species is not yet well known. If one takes into account the assemblages in which the species also occurs (Mejillones, Chile and Aegina, Greece), the range seems to be late Miocene-Pliocene.

$D$. heptacanthus appears to be a cannopiloid species of Distephanus coming, probably, from $D$. polyactis s.l. It must be also noted that an undescribed species of Cannopilus with a large basal ring consisting commonly of seven to eight radial horns and occurring in the middle Miocene of Romania, has among its most simple varieties specimens with seven and six radial horns very similar to $D$. heptacanthus.

\section{Genus PARADICTYOCHA Frenguelli}

Type species: Paradictyocha apiculata (Lemmermann).

Remarks: Frenguelli (1940) established $P$. polyactis (Ehr.) as the type species of this genus. Therefore, it would appear that the designation of $P$. apiculata (Lemm.) as type species would be contrary to the International codes of Botanical and Zooligical nomenclature. However it is necessary to take into consideration (a) that Frenguelli included in $P$. polyactis both the complete form of Dictyocha polyactis Ehr., and the mesocenoid form of Mesocena circulus var. apiculata Lemmermann, and (b) that Paradictyocha was understood by Frenguelli as consisting ordinarily of a ring resulting from fusion of the apical ring to the basal ring.

It seems that this is not the case with Paradictyocha apiculata. The fusion of the two rings does not seem to have actually taken place, although specimens of $D$. polyactis with very short lateral bars have been recorded (Gleser, 1966, pl. 24, figs. 7-9). The fusion does not explain the persistence of the vestiges of the lateral bars in the form of a row of spines alternately to the radial horns and sometimes pointed perpendicular to the basal ring.

Paradictyocha, if it is to be maintained, logically would be reduced to the mesocenoid species. It would thus represent mesocenoid species of Distephanus (D. polyactis only ?) as Septamesocena is for Corbisema and Mesocena for Dictyocha.
The data available at present seem to indicate that during the middle and upper Miocene, particularly, there was a group of Distephanus with large skeletons, the evolution of which consisted in the reduction of their apical apparatus. All of these more or less reduced forms seem to have originated from Distephanus ex gr. polyactis. The following linneages might be distinguished:

1) D. polyactis $-P$. apiculata-P. circulus;

2) D. ex gr. polyactis-Distephanus (? Paradictyocha) formosus (=Dictyocha formosa Bachmann)-?P. circulus Ling, 1972. D. formosa, found in the upper part of the middle Miocene, is a $D$. polyactis with the apical ring reduced to a few apical bars and with a reduced number of lateral bars. Vestiges of the latter have also been illustrated in this species. It is possible that it evolved toward forms completely lacking the apical apparatus, as those illustrated by Ling (1972) as M. circulus.

3) $D$. ex gr. polyactis with six to eight radial horns $-P$. septenaria (Schulz). Such reduced forms with or without vestiges of lateral bars have been considered by Schulz (1928) and Tsumura (1963) as different varieties of $M$. polymorpha. Except for their size, their morphology is wholly similar to that of the mesocenoid forms of D. octogonus (Ehr.). They are frequent in some middle Miocene sediments from Japan and Romania. The specimens included by Ling (1972) in M. circulus, discussed above, might also come from $P$. septenaria. In the middle Miocene from Romania, they are included as extreme variants in the normal curve of $P$. septenaria.

4) D. ex gr. polyactis-Distephanus (? Paradictyocha) paradistephanus (Tsumura)-P. hexagona (Haeckel). Dictyocha paradistephanus is in our opinion a dictyoid Distephanus resulting probably from an oblique fusion of the apical ring with the basal ring. The lateral bars shortened faster at one end of the longitudinal axis than at the other. The complete reduction of the apical apparatus is characteristic of $P$. hexagona (=Mesocena hexagona), the skeleton of which consists of a hexagonal basal ring. The specific name does not seem to be correct for this species. Haeckel described $M$. hexagona as a small form $(25=30 \mu)$ with an intermingled single ring with five or seven spines. This is not the case with the hexagonal Pacific species. It also does not appear to be a hexagonal form of $M$. elliptica or a Mesocena as was sometimes considered. The normal number of radial spines in Mesocena is four or two, corresponding to the number of radial spines in Dictyocha.

In these circumstances we have to choose between the following alternatives:

1) To include in Paradictyocha only $P$. apiculata and $P$. circulus, and probably $D$. polyactis, although by its morphology it is a Distephanus;

2) To include in Paradictyocha all these large species with generally more than six radial horns, with or without apical apparatus, since all of them show a trend toward reduction of the apical apparatus; or

3) To reject the genus Paradictyocha.

At present, the answer is not at all easy. Further investigations carried out on long sequences are needed to solve such questions. For the present report, our task was much easier because only two mesocenoid species, $P$. apiculata and $P$. circulus, have occurred in the samples investigated.

\section{Paradictyocha apiculata (Lemmermann)}

$$
\text { (Plate 9, Figures 3-6) }
$$

Mesocena circulus var. apiculata Lemmermann, 1901, p. 257, pl. 10, figs. 9, 10; Schulz, 1928, p. 242, fig. 10; Gemeinhardt, 1930, p. 32, fig. 19; Deflandre, 1932a, figs. 9, 10; Tsumura, 1963, pl. 6, figs. 8 , 9, pl. 19, fig. 4 ; pl. 20, figs. 1, 2 ; Ling, 1971, p. 692, pl. 1, figs. 14-16; Ling, 1972, p. 176, pl. 28, figs. 7, 8.

Distephanus polyactis f. mesocenoidea Deflandre, 1932b, p. 503, figs. 41, 42.

Paradictyocha polyactis f. mesocenoidea Frenguelli, 1940, p. 53, fig. 8a-c; Gleser, 1966, p. 278, pl. 28, fig. 1.

Paradictyocha apiculata Frenguelli, 1940, fig. $7 \mathrm{~h}$. Mesocena polyactis Tsumura, 1963, p. 42, fig. 4, pl. 14, fig. 1.

Mesocena circulus Tsumura, 1963, pl. 7, fig. 1.

Remarks: In most samples investigated within the interval 206-30, CC to $21, \mathrm{CC}$, this species, where it occurs, is generally much less frequent than $D$. polyactis. Only in 206-22, CC, did a higher frequency make possible a better knowledge of its variability 
and integrity. The specimens of this population are perfectly inscribed in a normal curve denoting that they represent a good species (see Figures 5,6 ). The number of radial horns in a row varies between 10 and 18 in this sample, and the maximum is reached for the specimens with 14 horns. In Figure 6 its place is given in comparison with three other populations of the species in three other localities.

It is seen that the range of variation varies with population from narrow to rather wide limits, and the maximum varies also with population from 12 radial horns to 15 , in all cases the integrity of the species is preserved.

The stratigraphical range of the species is generally limited to the interval found at Site 206, namely middle and late Miocene. Based on a probably very erroneous indication of Schulz $(1928$, p. 243 , fig. 15c) concerning a specimen from Oamaru, Ling (1972) considers that the known geologic range of the species is Eocene to Miocene. We doubt the Eocene occurrence of the species. Ling himself failed to observe such a species in the Oamaru Diatomite. We also have investigated this diatomite with the same result.

Dimensions: Diameter of the basal ring without radial horns, 70 to $118 \mu$.

\section{Paradictyocha circulus (Ehrenberg)}

(Plate 9, Figures 7-10)

Dictyocha (Mesocena) circulus Ehrenberg, 1840, p. 208 (fide Loeblich et al., 1968, p. 34, 84).

Mesocena circulus Ehrenberg, 1854, pl. 19, fig. 44; Loeblich et al., 1968, pl. 8, fig. 20; Martini, 1971, pl. 1, fig. 17; ?Mandra and Mandra, 1972 , p. 31 , fig. 36.

Mesocena elliptica verrucosa Dumitricà, 1972, pl. 2, fig. 6 .

Non M. circulus Lemmermann, 1901, p. 257; Schulz, 1928, p. 242,

fig. 14; Gemeinhardt, 1930 , p. 33, fig. 18; Frenguelli, 1940, p.

56, fig. 7i; Gleser, 1966, p. 285, pl. 29, fig. 8; Tsumura, 1963, p. 41 , pl. 7 , fig. 1 ; Ling, 1972 , p. 175 , pl. 28 , figs. 5,6 .

Description: Skeleton consisting of a simple circular or polygonal ring commonly armed with 18 to 25 short radial spines lying in the plane of the basal ring. Surface covered with scattered minute thorns. $75 \mu$

Dimensions: Diameter of the basal ring without spines, 58 to

Remarks: Because of the imperfection of the original illustration, this species has usually been confused with some small Paleogene species, with hornless $M$. elliptica, with $P$. apiculata, or other species. Ling considered $M$. circulus as reduced skeletons coming from Distephanus ex gr. polyactis and having 11 or 12 (as seen in his plate) fiarly long radial horns. Certainly they are not $P$. circulus. In the middle Miocene of Romania (Dumitricar, 1968, pl. 2, fig. 8), such specimens occur as extreme variants of what we name at present $P$. septenaria (Schulz). They have 5 to 10 , exceptionally more, radial horns and constitute a natural population of one species. The specimens illustrated by Ling belong probably, to a different but closely related species because if the species were $P$. septenaria, it would have been normal for him to have first found specimens with less radial horns and not only specimens with many horns. They come probably from $D$. formosus (Bachmann) by reduction of the apical apparatus.

Sigurd Locker, who has studied the silicoflagellates from the original slides of Ehrenberg kindly provided us a drawing of a specimen of $M$. circulus remarking that, "it has no true radial horns but only short spines in varying number." The specimens recovered in southwestern Pacific sediments are fairly similar to this drawing except for the fact that the radial spines are clearly distinct. The small teeth Locker has drawn between the small spines might be warty elevations of the superficial ornamentations as those observed in Plate 9, Figure 7.

Relating to the geologic range of the species, previous authors, on the basis of erroneous determinations, reported that it extends from Eocene to Miocene. Mandra and Mandra (1972), however, remarked that "recent work seems to indicate that this species might extend into the Pliocene."

Based on the southwestern Pacific cores and on the age of the sediments in which $P$. circulus certainly occurs, we think that the range of the species must be restricted particularly to Pliocene, with a short extension to late Miocene and Quaternary. At Site 206 it was recorded just within the boundaries of the Pliocene established by means of the foraminifers and calcareous nannoplankton. Martini (1971) also recorded this species from the Pliocene. One specimen probably belonging to the same species was found in the Pleistocene of the Mediterranean Sea at DSDP Site 127 (Dumitricà, 1972). Two other occurrences (Aegina, Greece, and San Felipe, Mexico) are of upper Miocene age, probably its upper part. No older occurrence of the species is known at present.

Assignment of the species to Paradictyocha and not to Mesocena is based on the opinion that it is derived from $P$. apiculata by reduction of the lateral spines (vestiges of the lateral bars of Distephanus). The upper Miocene specimen illustrated by Mandra and Mandra (1972), which is a little older than the specimens recovered in the southwestern Pacific, seems to be more primitive, preserving short spines in two rows, as in $P$. apiculata. The descendence of the species from $P$. apiculata is supported, not only by the comparable morphology of the two species, but also by succession of their geologic range at Site 206.

\section{Genus CANNOPILUS Haeckel, emend.}

Type species: Cannopilus hemisphaericus (Ehrenberg).

Diagnosis: Basal ring polygonal or circular, armed with five to twelve or more radial horns commonly directed obliquely downwards, seldon in the same plane or absent. Apical apparatus hemispheric to subspheric, composed of numerous apical windows and having generally a diameter equal to, or larger than, the diameter of the basal ring, seldom smaller. Number of lateral bars equal to number of sustaining spines or radial horns. Sustaining spines situated, as a rule, to the right of the point of junction of the lateral bars with the basal ring, seldom in this point.

Remarks: The discovery in the last decade of numerous fossil species answering to the old diagnosis of the genus Cannopilus opened a new chapter to its being better understood. According to the degree of complexity of its apical apparatus it is to be divided into two distinct genera. A main criterion for this division is to be the type of connection between the apical apparatus and the basal ring, or, more precisely, the ratio between the number of the lateral bars and number of sustaining spines or exceptionally of radial horns, when the sustaining spines are missing. It is known that the number of radial horns varies independently from the number of lateral bars, they being able to multiply or reduce. This ratio corresponds to the trend for complication of the apical apparatus not only by multiplication of the number of apical, but also of lateral windows and bars.

In order to understand the value of such a criterion it is to be noted that in the silicoflagellates belonging to Corbisema, Dictyocha, Deflandryocha, and Distephanus, this ratio is normally 1 because the number of the lateral bars is equal to the number of sustaining spines. This equality is due to the fact that the sustaining spines are connected by their origin from the lateral bars (Dumitricà, 1967, p. 4). A few examples follow:

\begin{tabular}{lcc}
\hline \multicolumn{1}{c}{ Species } & Lat. Bars & Lat. Bars \\
\cline { 2 - 3 } & Sust. Spines & Corners or Radial Horns \\
\hline Vallacerta hortoni & $4 / 4-6 / 6$ & - \\
Corbisema inermis & $3 / 3$ & $3 / 3$ \\
Corbisema inermis & $2 / 2$ & $2 / 2$ \\
disymmetrica & & \\
Corbisema triacantha & $3 / 0$ & $3 / 3$ \\
Corbisema geometrica & $3 / 3$ & $3 / 3$ \\
Dictyocha fibula & $4 / 4$ & $4 / 4$ \\
Distephanus crux & $4 / 4$ & $4 / 4$ \\
Distephanus bachmanni & $4 / 4$ & $4 / 6$ \\
Distephanus stauracanthus & $4 / 4$ & $4 / 8$ \\
Distephanus speculum & $6 / 5$ & $6 / 6$ \\
Distephanus octogonus & $8 / 0$ & $8 / 8$ \\
Distephanus polyactis & $8 / 0(8) .$. & $8 / 8 . .$. \\
\hline
\end{tabular}

The species of Cannopilus, as understood in this report, preserve this unitary ratio. 


\begin{tabular}{llll}
\hline \multicolumn{1}{c}{ Species } & \multicolumn{1}{c}{ Lat. Bars } & & Lat. Bars \\
Cant. Spines & & Rad. Horns \\
\hline Cannopilus hemisphaericus & $6 / 6$ & $6 / 6$ \\
Cannopilus depressus & $5 / 0$ & $5 / 5$ \\
Cannopilus longispinus & $7 / 7,8 / 8 \ldots$ & $7 / 7,8 / 8 \ldots$ \\
Cannopilus indaensis & $8 / 8$ & $8 / 8,8 / 7,8 / 6$ \\
Cannopilus ichikawai & $9 / 9 \ldots 12 / 12$ & $9 / 9 \ldots 12 / 12$ \\
\hline
\end{tabular}

In the second group of the old Cannopilus, this ratio reaches double, triple, or greater values, the number of lateral bars being double, triple, or greater in comparison with the number of sustaining spines or radial horns. The species having these ratios are included in the genus Halicalyptra, recently reconsidered as a silicoflagellate but believed to the synonymous with Cannopilus (Loeblich et al., 1968; Lipps, 1970). In the species of this genus the discussed ratio is 15 to $17 / 4$ in $H$. virginica, 12 to $15 / 5$ in $H$. picassoi, and 7 to $10 / 4$ in $H$. miltiadei.

Cannopilus is probably a genus of middle latitudes. It has not yet been recorded in equatorial sediments, and it is also generally much rarer in pelagic sediments than in nonpelagic ones. For example, its species are known from north latitude localities in Japan, California, northeastern Pacific (Experimental Mohole drilling, DSDP Site 33), Virginia (Richmond locality of Ehrenberg), Spain, Italy, Austria, and Romania.

In the southwestern Pacific sediments, Cannopilus was rather rarely encountered, being represented by $C$. hemisphaericus and by one or two undetermined species.

\section{Cannopilus hemisphaericus (Ehrenberg) (Plate 10, Figure 6)}

Dictyocha hemisphaerica Ehrenberg, 1844, p. 258, 266 (fide Loeblich et al., 1968, p. 38, 100).

Cannopilus hemisphaericus Haeckel, 1887, p. 1569; Lemmermann, 1901 , p. 268, pl. 11, fig. 21.

Remarks: Very rare species. Several types of specimens have been recorded in the southwestern Pacific sediments that have hexagonal basal ring and fairly simple apical apparatus answering to the diagnosis of $C$. hemisphaericus. From all of these types, only the small specimens with the apical apparatus composed of seven to eight windows have been assigned to it because they are similar to the first illustration of the species. The others aryincluded in Cannopilus spp. C. hemisphaericus was found in 206-31, CC, with a frequency of about 2 percent, and in 206-42, CC. to $36 \mu$.

Dimensions: Length of skeleton, 68 to $75 \mu$ and of basal ring, 34

\section{Cannopilus spp.}

(Plate 10, Figures 8-12; Plate 11, Figures 1-5)

Remarks: Except for $C$. hemisphaericus, assignment of the other specimens of Cannopilus to one of the known species is rather diffiuclt. For example, the specimen illustrated in Plate 10, Figures 10-11 is quite similar to $C$. ernestinae Bachmann because of its pentagonal basal ring, absence of sustaining spines, robustness of skeleton, and characteristics of the apical apparatus. The specimen illustrated in Plate 10, Figures 8-9 might also represent a hexagonal form of the same species. Both forms, pentagonal and hexagonal, have been found in the same sample, 206-32, CC. The difficulty in ascribing them to $C$. ernestinae lies in the fact taht in the sample cited the forms with six radial horns are most frequent ( 9 specimens), whereas, the pentagonal forms are represented only by one specimen. There are also heptagonal forms ( 2 specimens). $C$. ernestinae in topotype (Wakura Beds) material is known as commonly having pentagonal forms and only seldom having hexagonal ones. With the same characters the species was found by us in the DSDP Sample 33-15-1, 75-77 cm.

The specimens illustrated in Plate 10, Figure 12 and Plate 11, Figures 1,2 might be ascribed to $C$. depressus (=C. sphaericus) by the high number of apical windows, but its basal ring is larger than the apical apparatus and the radial horns are very little inclined under the plane of the basal ring. The two specimens with seven radial horns and the one with six have been found in 206-31, CC beside the small skeletons of $C$. hemisphaericus.

Rare specimens with hexagonal basal ring and with apical apparatus of $C$. hemisphaericus type (Plate 11, Figures 3,4 ) have been recorded in 206-35, CC and 206-22, CC. They have not been ascribed to this species because their basal ring is much larger. Thus, the length of the skeleton of these forms is 82 to $94 \mu$ and of the basal ring, 64 to $70 \mu$.

\section{Genus HALICALYPTRA Ehrenberg, emend.}

Halicalyptra Ehrenberg, 1847 (fide Loeblich et al., 1968, p. 51, 124).

Type species: Halicalyptra virginica Ehrenberg, fixed by Campbell, 1954).

Diagnosis: Basal ring polygonal, armed commonly with four to six radial horns directed obliquely downwards, seldom in the same plane or migrated onto the apical apparatus, or reduced. Apical apparatus subspheric, composed of numerous apical windows and connected to the basal ring by lateral bars, the number of which is as much as double, triple or greater in comparison with the number of sustaining spines or radial horns. Sustaining spines located in the middle of the basal bars or absent.

Remarks: The genus Halicalyptra, initially ascribed to the Polycystine Radiolaria, was very schematically described by its author and included species belonging to it, to Cannopilus, or to radiolarians. Haeckel (1887) considered it also as a radiolarian. In 1954, Campbell designated Halicalyptra virginica as its type species. As this species is a silicoflagellate, Halicalyptra is to be excluded from Radiolaria. Loeblich et al. (1968), who considered it for the first time as a silicoflagellate, believed that it includes Cannopilus in its synonymy. Later, Lipps (1970) also considered that Cannopilus is a junior synonym of Halicalyptra.

As was demonstrated above (see Cannopilus), the two genera are independent taxa. They are differentiated from one another by the value of the ratio between the number of the lateral bars and the number of the sustaining spines or radial horns.

Halicalyptra is certainly derived from Cannopilus. However, no intermediate form has hitherto been found and thus we do not know yet when and how the passage between these two genera took place. We suppose that the doubling of lateral bars in Halicalyptra has been performed by the shortening and finally complete reduction of the lateral bars of Cannopilus. The two apical bars connected at the upper end of a lateral bar become by this phenomenon secondary lateral bars of twice the number. This might explain not only why the number of "lateral bars" in Halicalyptra is double, or more, that in Cannopilus, but also why the lateral windows are generally as large as the apical windows, and not larger as in Cannopilus.

The following species are to be included in this genus:

1) Halicalyptra virginica Ehrenberg = Cannopilus tetraceros Deflandre in Bachmann and Ichikawa (1962), with four radial horns migrated onto the apical apparatus and lacking sustaining spines;

2) Halicalyptra picassoi (Stradner), with generally five radial horns and with or without sustaining spines; and

3) Halicalyptra miltiadei (Dumitrica) with four radial horns and with sustaining spines.

Stragigraphical range: missle Miocene, possibly also upper part of early Miocene and lower part of late Miocene.

In the southwestern Pacific sediments only $H$. picassoi has been recorded.

\section{Halicalyptra picassoi (Stradner) (Plate 10, Figure 5)}

Cannopilus picassoi Stradner, 1961, p. 92, figs. 101-104; Bachmann in Bachmann et al., 1965, p. 153, pl. 20, figs. 74-81; pl. 22, figs. 17-19; Bachmann and Papp, 1968, pl. 3, fig. 16; Hajos, 1968, p. 70 , pl. 6, fig. 5 ; non Ling, 1972 , p. 149, pl. 23, figs. 6 , 7.

Remarks: Two specimens, fairly conformable to the Austrian specimens, have been found in the lower part of the middle Miocene at Site 206 (Sample 206-31, CC). They have a pentagonal basal ring with five radial horns, five sustaining spines, and a globular apical apparatus connected to the basal ring by more than ten bars. The 
apical apparatus is composed of numerous apical windows and is armed with several accessory spines situated on the upper half.

Dimensions: Diameter of the basal ring, $30 \mu$, of the apical apparatus, $35 \mu$; height of skeleton without radial and apical spines, $31 \mu$.

These two specimens are the only record of the species in Pacific sediments. As for the two Italian specimens illustrated by Ling $(1972$, pl. 23, figs. 6,7$)$, they do not seem to belong to this species. The first specimen has a robust skeleton never observed in this species and seems to be of the same type as the Mediterranean specimen illustrated by Dumitrica (1972, pl. 12, fig. 20). The second seems to have a number of lateral bars equal to the number of sustaining spines or radial horns, and, consequently, must be excluded from Halicalyptra.

According to the data available at present, the occurrence of $H$. picassoi is restricted to the D. stauracanthus Subzone and to some levels below it, in the $C$. triacantha Zone. In this last position it was recorded in Austria. In Pacific sediments investigated, and in Romania, the species occurs in the $D$. stauracanthus Subzone.

\section{INCERTAE SEDIS AND DIATOMS}

\section{Genus MACRORA Hanna \\ Macrora stella (Azpeitia) \\ (Plate 1, Figure 11)}

Macrora stella (Azpeitia) Hanna, Hajós, 1968, p. 85, pl. 9, figs. 2, 6 . Pseudorocella corona Deflandre, 1946, p. 337, fig. 4; Dumitricǎ, 1972, p. 908, pl. 1, fig. 7.

Remarks: Only one specimen was found, in 206-29, CC.

\section{Genus ROCELLA Hanna \\ Rocella gemma Hanna \\ (Plate 11, Figures 7-12)}

Rocella gemma Hanna, 1930, J. Pal., vol. 4, p. 415, pl. 40, figs. 8-18 (fide Loeblich et al., 1968, p. 61, 141, pl. 34, figs. 1-11; Ling, 1972, p. 192, pl. 31, figs. 12-15.

Remarks: In his last paper, Ling (1972) considers this monospecific genus to be of a still unknown nature. In accord with Lipps (1970), we include it among diatoms. The valves are not simple discs as was considered by previous authors but have short perforate margins (Plate 11, Figure 12). No proof that the large pores of the valves have resulted from dissolution of the silica, as Lipps (loc. cit.) supposed, was encountered in any specimen. In this respect, our observations are in agreement with those of Ling (loc. cit.).

At Site 206, R. gemma occurs in the uppermost Oligocene. The highest frequency was recorded in the uppermost part of the Dorcadospyris ateuchus Zone and in the lowest part of the Lychnocanoma elongata Zone. The species was uninterruptedly recorded in the lower Miocene and, sporadically, up to upper Pliocene. Some of the younger occurrences probably result from reworking.

Because of its first occurrence and high frequency to the lower boundary of its range, $R$. gemma seems to be a good time marker. Ling (1972) remarked a similar occurrence at the base of the Miocene or possibly the top of the Oligocene.

\section{Genus TEPKA Sanfilippo and Riedel}

Tepka perforata Sanfilippo and Riedel

Tepka perforata Sanfilippo and Riedel in Sanfilippo et al., (in press), p1. 6, figs. 18-20.

Remarks: Sanfilippo and Riedel consider this incertae sedis fossil as having a restricted stratigraphic range. At Site 206 its occurrence extends over a longer interval, from the top of the Dorcadospyris ateuchus to the D. alata Zone.

\section{REFERENCES}

Bachmann, A., 1970a. Silicoflagellaten aus dem oberösterreichischen Egerien (Oberoligozän): Verh. Geol. Bundesanst., pt. 2, p. 275-305.

1970b. Catalogus fossilium Austriae: H.1b, Flagellata (Silicoflagellata), p. 1-28. 1971a. Silicoflagellaten aus dem oberen Badenien von Walbersdorf, Burgenland: Sitzungsber. Osterr. Akad. Wiss., mathem.-naturw. K1., v. 179, pt. 1, f. 1-4, p. 55-72.

1971b. Silicoflagellaten aus dem Eggenburgien von Ernstbrunn (Niederösterreich): Verh. Geol. Bundesanst. pt. 3, p. 552-569.

Bachmann, A. and Ichikawa, W. 1962. The silicoflagellides in the Wakura Beds, Nanao City, Prefecture Ishikawa, Japan: Sci. Repts. Kanazawa Univ., v. 8, no. 1, p. 161-175.

Bachmann, A., Papp, A., and Stradner, H,, 1963. Mikropaläontologische Studien im "Badener Tegel" von Frättingsdorf, N. O: Mitt. Geol. Gesel. Wien, v. 56, f. 1, p. 117-210.

Bachmann, A. and Papp, A., 1968. Vorkommen und Verbreitung des Silicoflagellaten im Neogen Osterreichs: Giorn. Geol. Bologna, ser. 2, v. 35, f. 2, p. 117-126.

Campbell, A. S,, 1954. Radiolaria. In Treatise on Invertebrate Paleontology. (R. C. Moore ed.): Univ. Kansas Press and Geol. Soc. Am., pt. D, Protista 3, p. 11-163.

Carnevale, P., 1908. Radiolarie e silicoflagellati di Bergonzano (Reggio Emilia): Mem. R. Inst. Veneto, Sci., Lett. Arti, vol. 28 , no. 3 , p. 1-46.

Deflandre, G., 1932a. Les Silicoflagellés des terres fossiles à Diatomées: Soc. Franc. Microscopie Bull., v. 1, p. 10-20. $1932 b$. Sur la systématique des Silicoflagellés: Soc. Bot. France Bull., v. 79, p. 494-506. 1940. L'origine phylogénétique des Lyramula et l'évolution des Silicoflagellidées: C. R. Acad. Sci. Paris, v. 211 , p. $508-510$.

1946. Phyllodictyocha nov. gen., Silicoflagellidés et formes affines du Miocène de Hongrie: Soc. Bot. France, Bull., v. 93, no. 9, p. 335-337.

1950. Contribution à l'étude des Silicoflagellidés actuels et fossiles: Microscopie, v. 2, p. 1-82.

Desikachary, T. V. and Maheshwari, C. L., 1956. Fossil silicoflagellates from Colebrook and Nancoori Islands: Indian Bot. Soc. J., v. 35, p. 257-264.

Dumitricà, P., 1967. Dictyocha bachmanni n. sp. et considérations sur la lignée phylogénétique Dictyocha crux-D. stauracantha-D. bachmanni. Cahiers Micropaléont., ser. I, no. 4 (Arch. Orig. Centre Docum. C.N.R.S., no. 435).

1968. Consideratii micropaleontologice asupra orizontului argilos cu radiolari din Tortonianul regiunii carpatice: Stud. Cerc. Geol., Geofiz. Geogr., ser. geol., v. 13 , no. 1 , p. $227-241$.

1972. Miocene and Quaternary silicoflagellates in sediments from the Mediterranean Sea. In Ryan, W.B.F., Hsü, K. J., et al. Initial reports of the Deep Sea Drilling Project, Volume XIII: Washington (U.S. Government Printing Office), p. 902-933.

Ehrenberg, C. G., 1854. Microgeologie: Leipzig (Leopold Voss), p. 1-31.

Frenguelli, J., 1940. Considerationes sobre los silicoflagelados fosiles: Rev. Mus. La Plata, n. ser., (Paleontol. no. 7), v. 2, p. 27-112.

Gemeinhardt, K., 1930. Silicoflagellatae. In L. Rabenhorst's Kryptogamen-Flora von Deutschland, Osterreich und der Schweiz: Leipzig, v. 10 (f.2)., p. 1-87.

Gleser, S. I., 1966. Kremnevye zhgutikovye vodorosli (Silik oflagellaty). Silicoflagellatophyceae: Flora Sporovykh Rasteniy SSSR (Flora Plantarum Cryptogamarum URSS), v. 7, Akad. Nauk SSSR, Bot. Inst. V. L. Komarova, Moscow, Leningrad, p. 1-330. 
Haeckel, E., 1887. Report on the Radiolaria collected by H.M.S. Challenger during the years 1873-1876: Rept. Sci. Results Voyage of H.M.S. Challenger, 1873-1876, Zool. v. 18, p. 1-1803.

Hajós, M., 1968. Dia Diatomeen der Miozän en Ablagerungen des Matravorlandes. Geol. Hungarica, ser. paleontol., f. 37 , p. 1-401.

Hays, J. D. et al., 1972. Initial Reports of the Deep Sea Drilling Project, Volume IX. Washington (U. S. Government Printing Office).

Ichikawa, W., Norio, F. and Bachmann, A., 1964. Fossil diatoms, pollen grains and spores, silicoflagellates and archaeomonads in the Miocene Hojuji Diatomaceous Mudstone, Noto Peninsula, central Japan: Sci. Repts. Kanazawa Univ., v. 9, no. 1, p. 25-118.

Ichikawa, W., Shimizu, I. and Bachmann, A., 1967. Fossil silicoflagellates and their associated uncertain forms in Iida Diatomite, Noto Peninsula, central Japan: Sci. Repts. Kanazawa Univ., v. 12, no. 1, p. 143-172.

Jerkovic, L., 1969. Les silicoflagellides fossiles des environs de Zagreb, de Bosanska Kostajnica et de Derventa (Jougoslavie): God. Biol. Inst. Unit. Sarajevu, v. 22, p. 21-127.

Lemmermann, E., 1901. Silicoflagellatae. Ergebnisse einer Reise nach dem Pacific. H. Schauinsland 1896/97: Ber. deutsch. bot. Gesel., v. 19, p. 247-271.

Ling, H.-Y, 1970. Silicoflagellates from central north Pacific core sediments: Am. Paleont. Bull., v. 58, no. 259, p. 81-129.

1971. Silicoflagellates and ebridians from the Shinzan Diatomaceous Mudstone member of the Onnagawa formation (Miocene), northeast Japan: Plankt. Conf., 2nd, Roma, 1970, Proc. (A. Farinacci Ed.), p. 689-703.

, 1972. Upper Cretaceous and Cenozoic silicoflagellates and ebridians: Am. Paleont. Bull., v. 62, no. 273 , p. $133-229$.
Lipps, J. M., 1970. Ecology and evolution of silicoflagellates: North Am. Paleont. Convention Proc., 1969, part G, p. 965-993.

Loeblich, A. R., III, Loeblich, L. A., Tappan, H., and Loeblich, A. R., Jr., 1968. Annotated index of fossil and Recent silicoflagellates and ebridians with descriptions and illustrations of validly proposed taxa: Geol. Soc. Am. Mem., 106, p. 1-319.

Mandra, Y. T., 1968. Silicoflagellates from the Cretaceous, Eocene, and Miocene of California, U.S.A.: Calif. Acad. Sci. Proc., ser. 4, v. 36, no. 9, p. 231-277.

Mandra, Y. T. and Mandra, H., 1972. Paleoecology and taxonomy of silicoflagellates from an Upper Miocene diatomite near San Felipe, Baja California, Mexico. Calif. Acad. Sci. Occ. Papers, no. 99, p. 1-35.

Martini, E., 1971. Neogene silicoflagellates from the equatorial Pacific. In Winterer, E. L., Riedel, W. R., et al., Initial Reports of the Deep Sea Drilling Project, Volume VII: Washington (U. S. Government Printing Office), p. 1695-2708

Sanfilippo, A., Burckle, L. H., Martini, E., Riedel, W. R. Radiolarians, diatoms, silicoflagellates and calcareous nannofossils in the Mediterranean Neogene. Micropaleontology, (in press).

Schulz, P., 1928. Beiträge zur Kenntnis fossiler und rezenter Silicoflagellation: Bot. Archiv., v. 21, p. 225-292.

Stradner, H., 1961. Über fossile Silicoflagelliden und die Möglichkeit ihrer Verwendung in der Erdölstratigraphie: Erdöl u. Kohle, v. 14, no. 2, p. $87=92$.

Tsumura, K., 1963. A systematic study of Silicoflagellatae: Hokohama Numicipal Univ., J., ser. C-45, no. 146, p. 1-86.

Tynan, E. J., 1957. Silicoflagellates of the Calvert formation (Miocene) of Maryland: Micropaleontology, v. 3, p. 127-136.

Zanon, D. V., 1934. Silicoflagellatae fossili italiane: Acta Pontif. Acad. Sci. Nov. Lincei Roma, v. 87, p. 40-82. 
PLATE 1

All figures $\times 570$

Figures 1-3 Lyramula furcula Hanna. Figure 1, 206C-9, CC; Figure 2, 206-35, CC; Figure 3, 206-29, CC.

Figures 4, 5, Naviculopsis biapiculata (Lemmermann), Figure 4, 7-10 DSDP 206-45, CC; Figures 5, 9, 10, 206-35, CC; Figure ?7, DSDP 206-26, CC; Figure ?8, 206C-9, CC.

Figures 6,7 Naviculopsis foliacea Deflandre. Figure 6, 206C-8, CC; Figure ?7, 206-26, CC.

Figure $11 \quad$ Macrora stella (Azpeitia), 206-29, CC.

Figures 12-14 Naviculopsis quadrata ssp. pacifica n. ssp. 206-35, CC.

Figure $15 \quad$ Naviculopsis sp. 206-32, CC. 


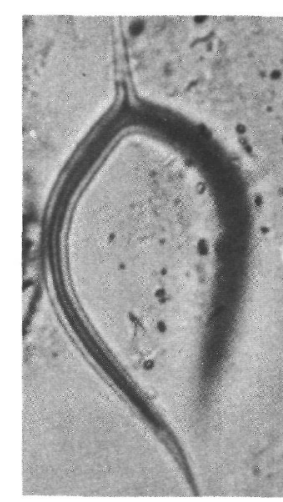

1
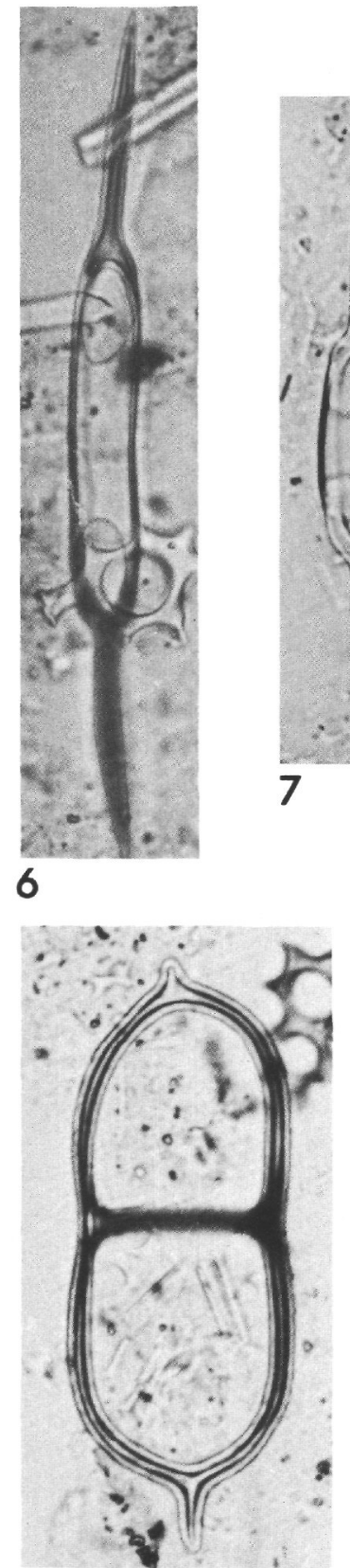

12
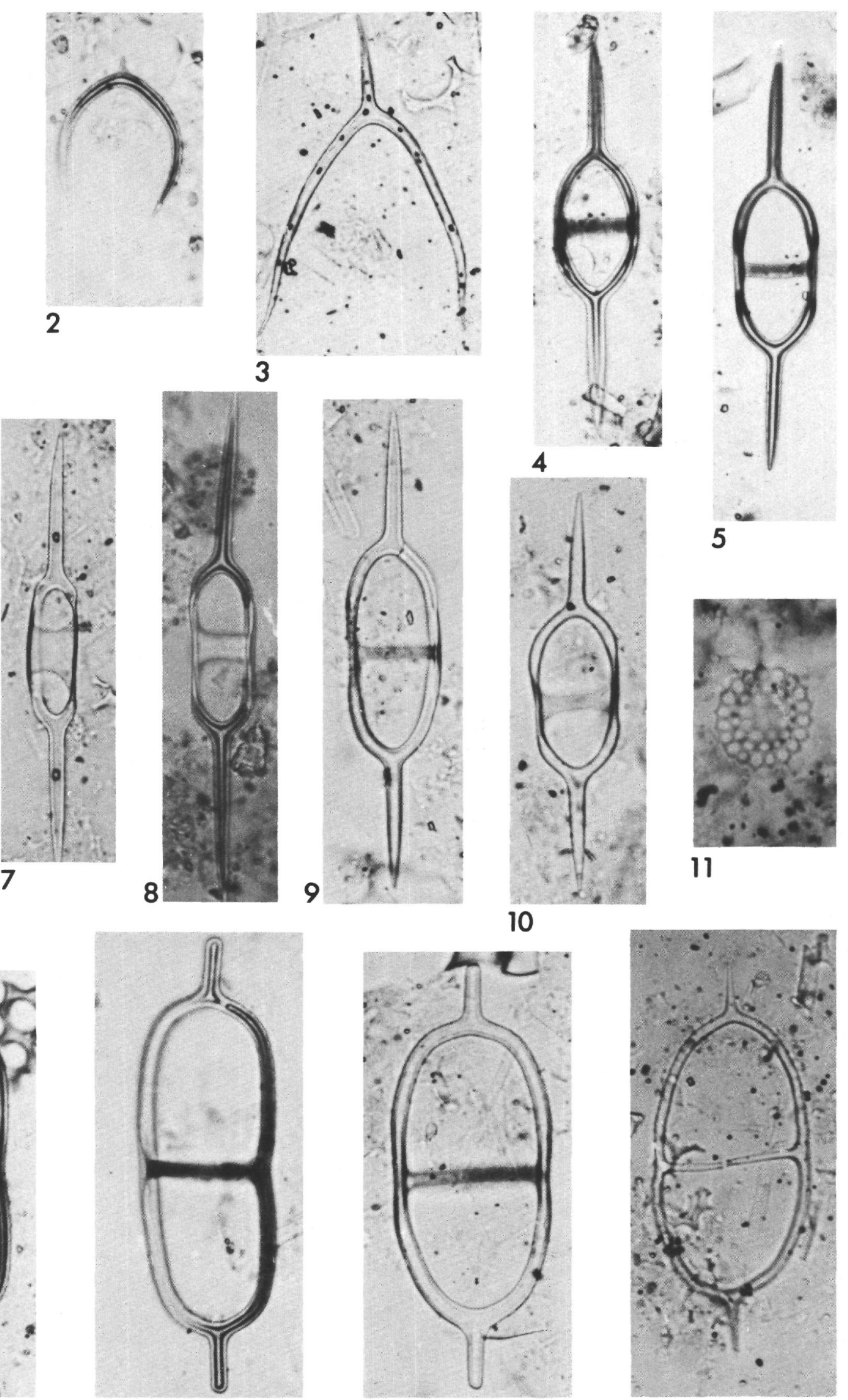

13
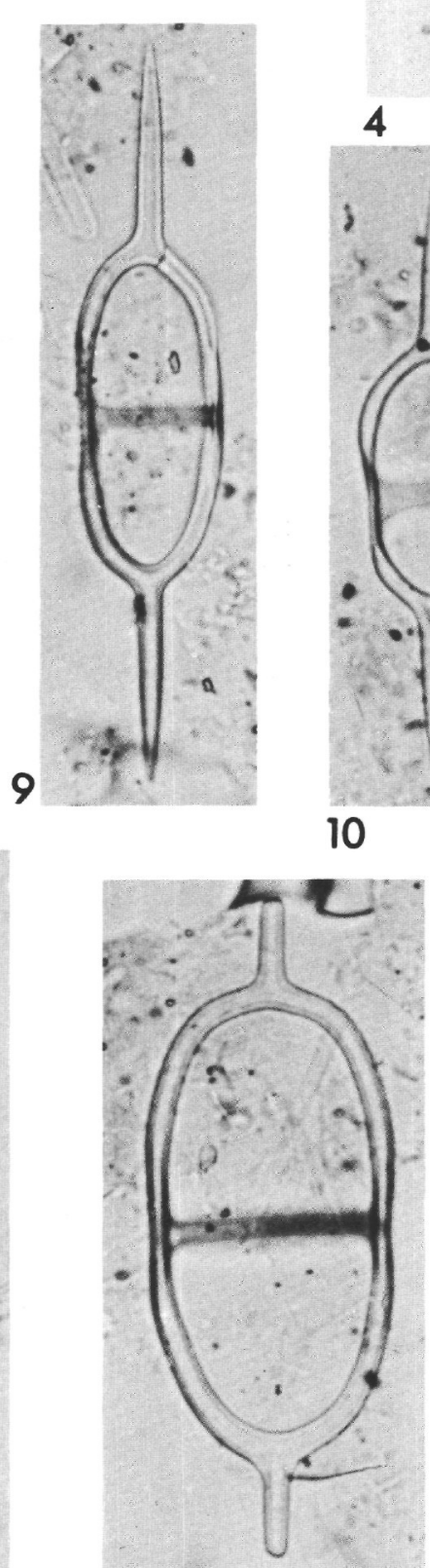

14

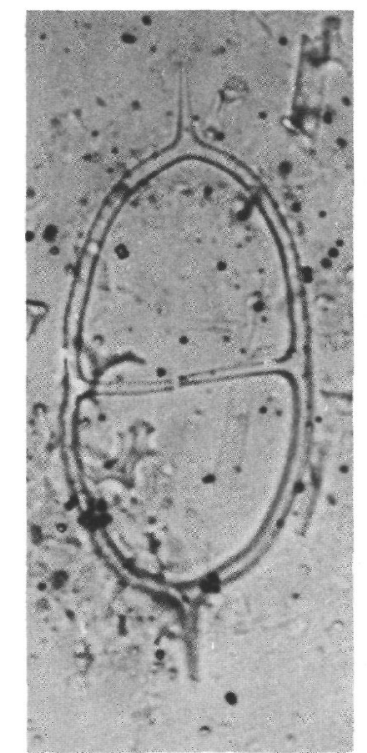

15 
PLATE 2

All figures $\times 570$

Figures 1-3 Corbisema triacantha (Ehrenberg). Figure 1, 206-35, CC; Figures 2, 3, 206-26, CC.

Figures 4-13, Dictyocha fibula ssp. aspera Lemmermann. Figures 4, 15, $16 \quad 6-8,11-13,205-4, \mathrm{CC}$; Figures 5, 9, 10, ?15, 16, $205-5-1,18-20 \mathrm{~cm}$.

Figures 14, 17 Dictyocha fibula Ehrenberg. 206-18, CC. 
Plate 2
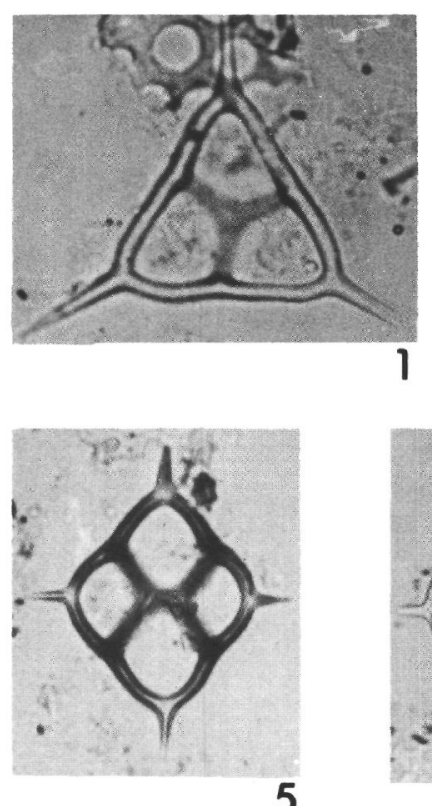

5
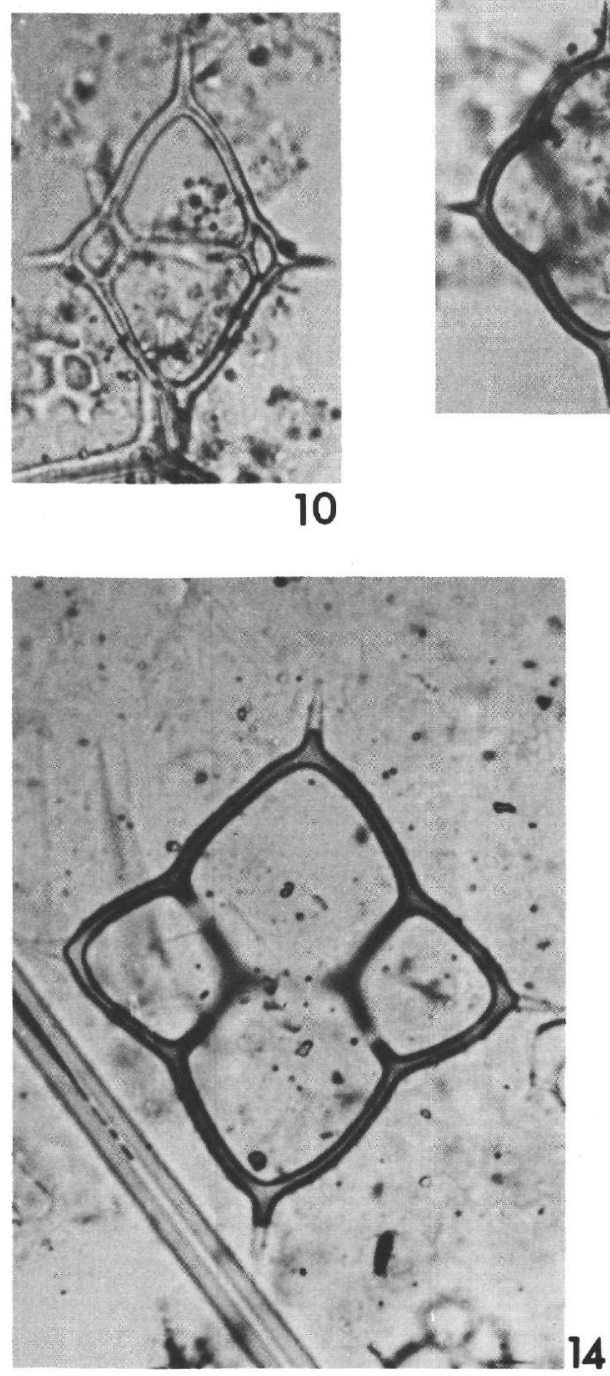
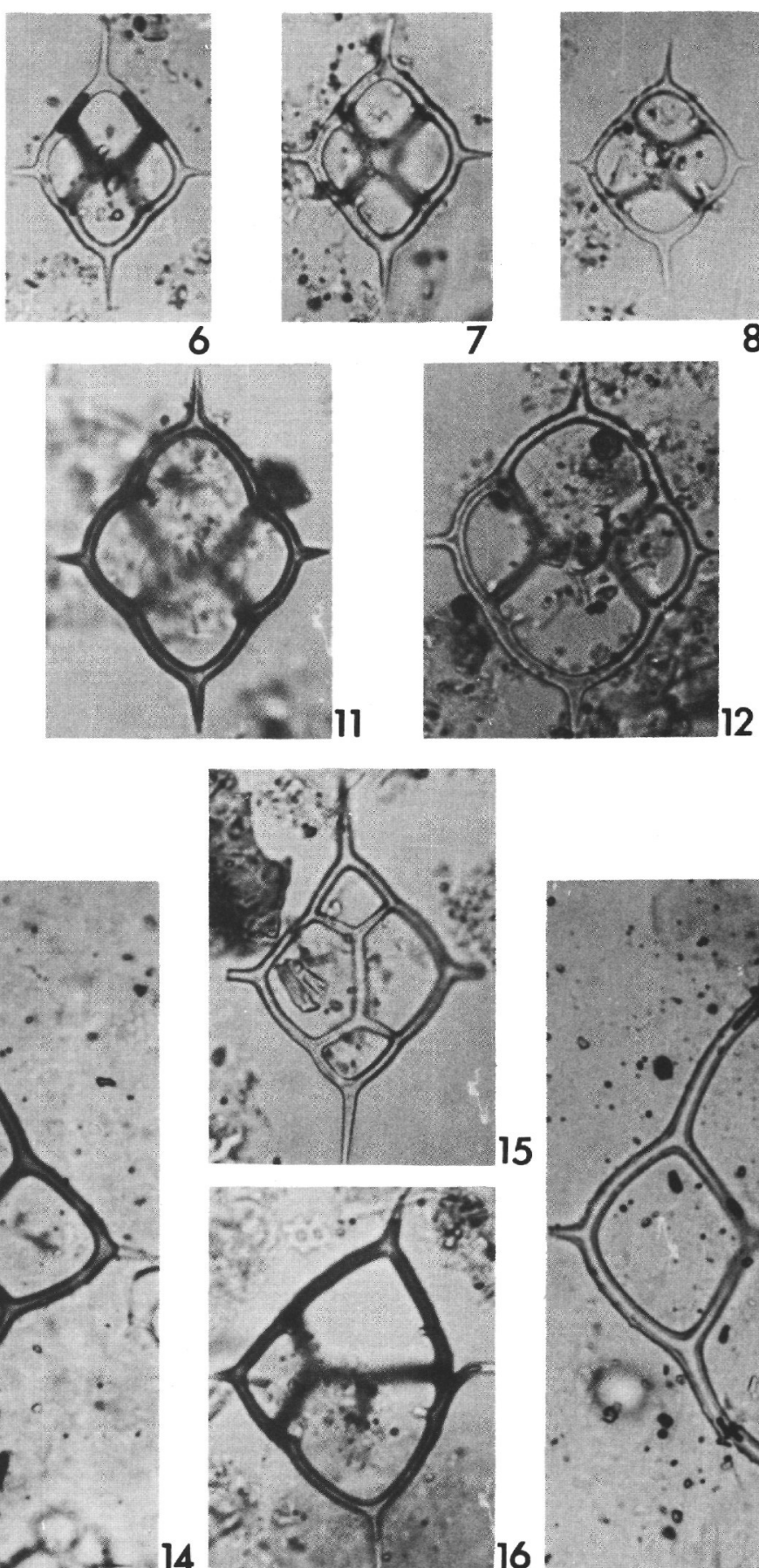
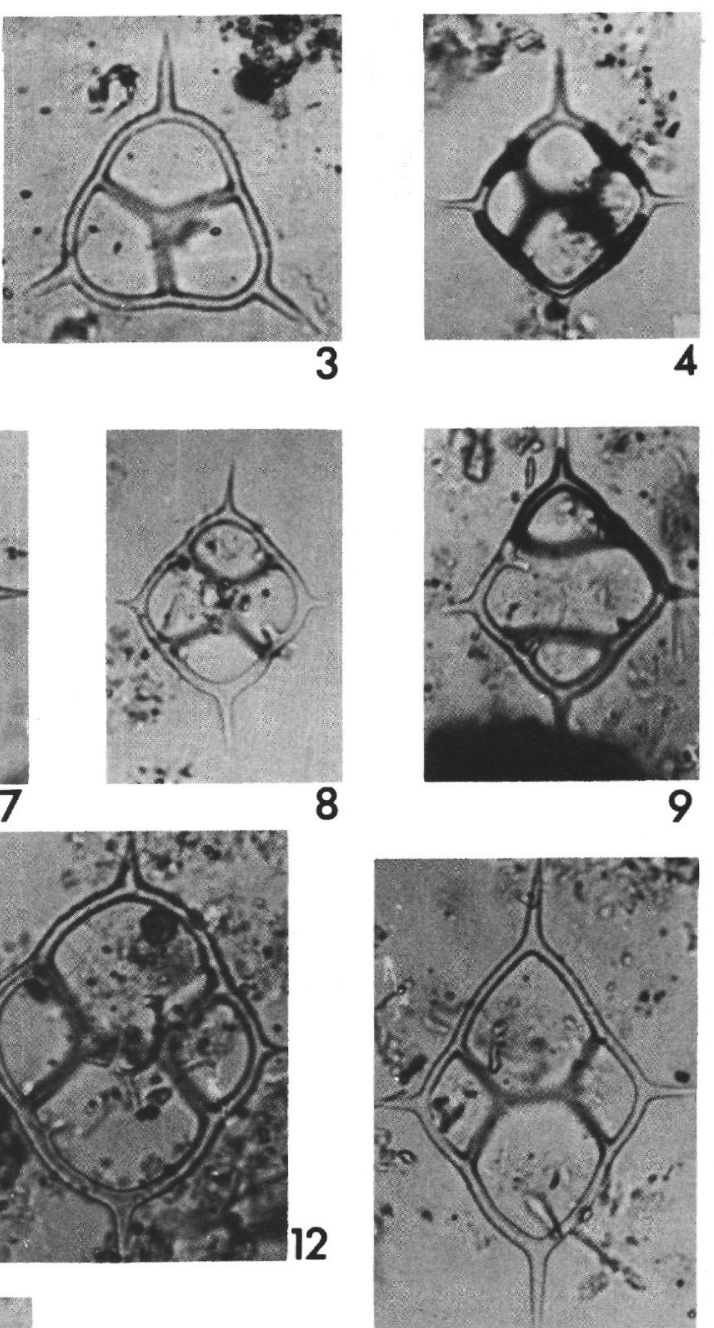

13

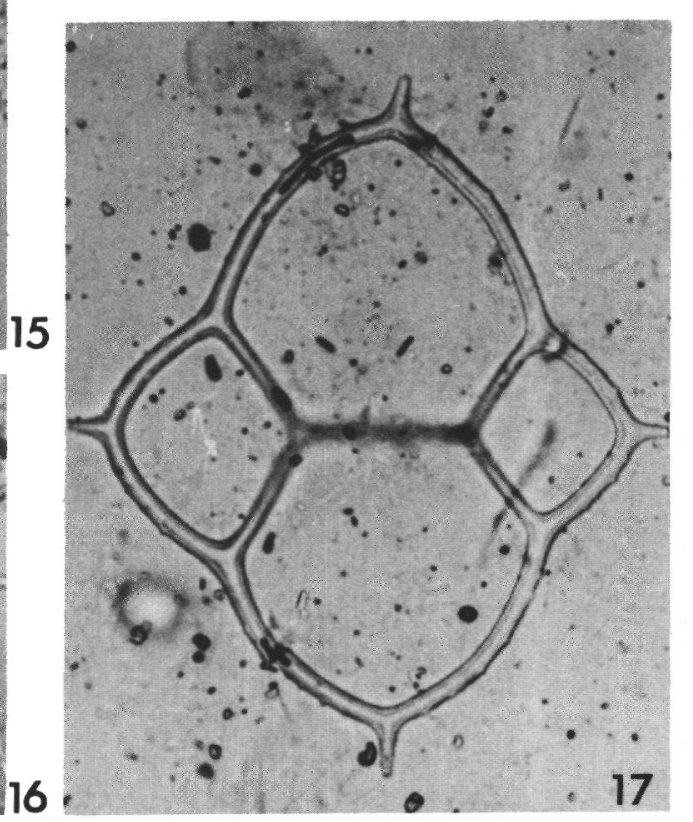




\section{PLATE 3}

All figures $\times 570$

Figures 1-3 Dictyocha fibula Ehrenberg. Figures 1, 3, 206-32, CC; Figure 2, 206-18, CC.

Figures 4-7 Dictyocha lingi Dumitrica. Figure 4, incipient form, 206-8, CC; Figures 5-7, normal forms, 206-5, CC.

Figures 8-12 Dictyocha perlaevis Frenguelli. Figure 8, 206-14, CC; Figure 9, 206-20, CC; Figure 10, 206-5, CC; Figure 11, 206-8, CC; Figure 12, 206-16, CC.

Figures 13-15 ?Dictyocha stapedia Haeckel. 206-12, CC. 
PLATE 3
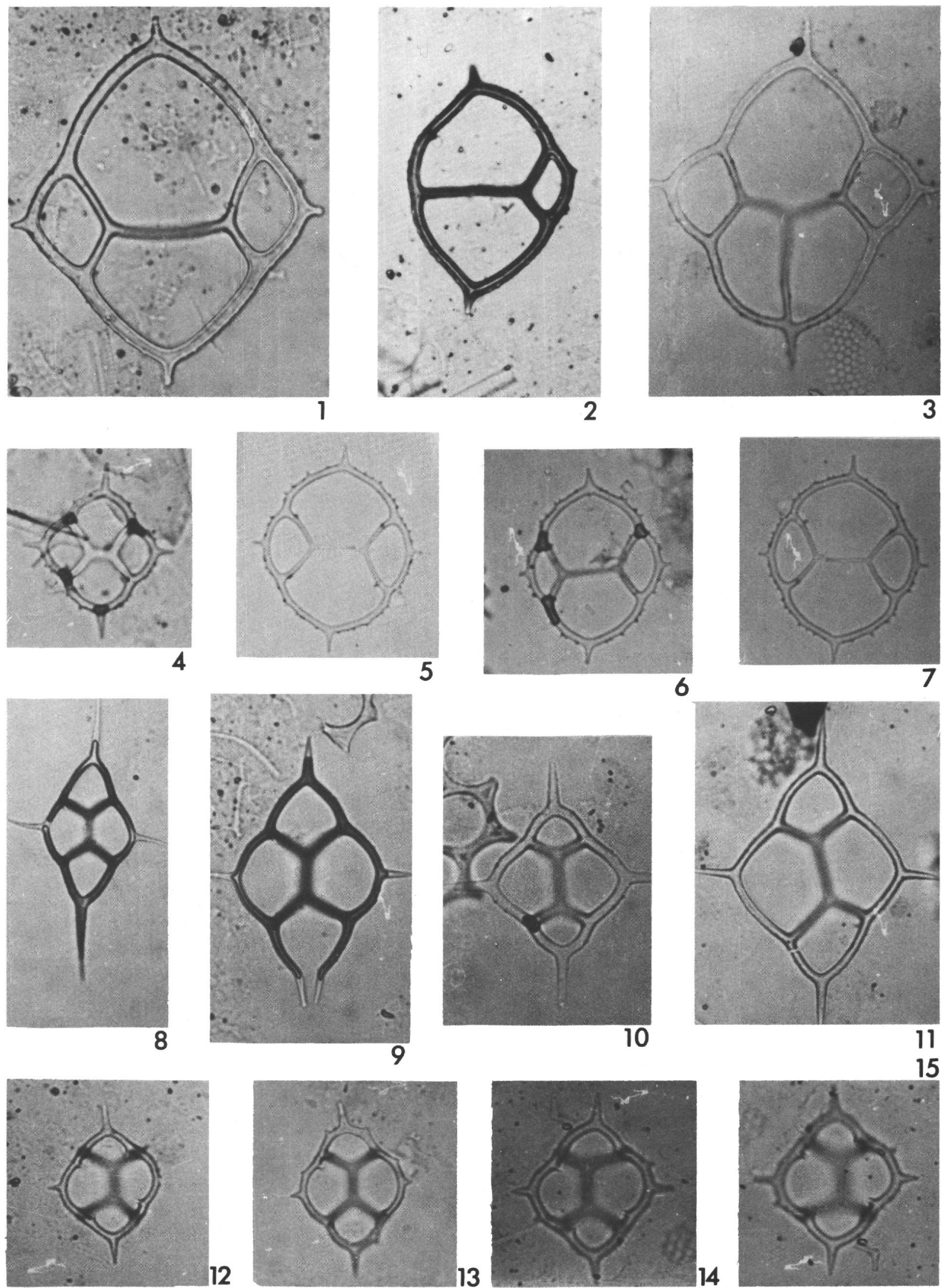

12
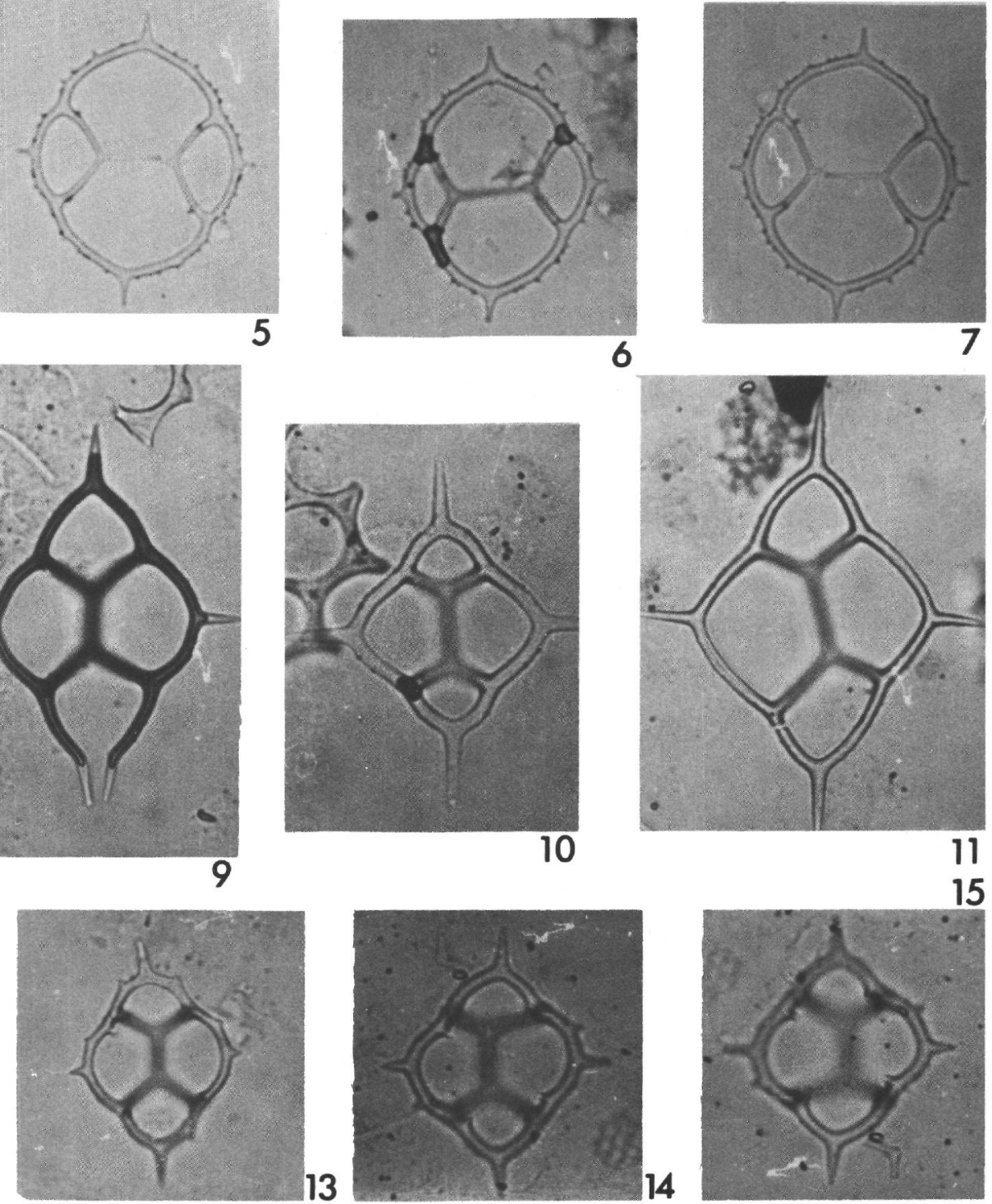
PLATE 4

All figures $\times 570$

Figures 1, 2 Dictyocha perlaevis Frenguelli. Figure 1, 206-20, CC; Figure 2, 206-13, CC.

Figure 3 Dictyocha sp. 206-5, CC.

Figures 4,6 Dictyocha stapedia Haeckel. Figure 4, 206-19, CC; Figure 6, 206-12, CC.

Figures 5-8 Dictyocha messanensis Haeckel. Figure ?5, 206-13, CC; Figures ?6, 8, 206-12, CC; Figure 7, 206-8, CC.

Figures 9-11 Dictyocha aculeata Lemmermann. 206-5, CC.

Figure 12 Dictyocha fibula Ehrenberg, mesocenoid form, 206-18, CC. 

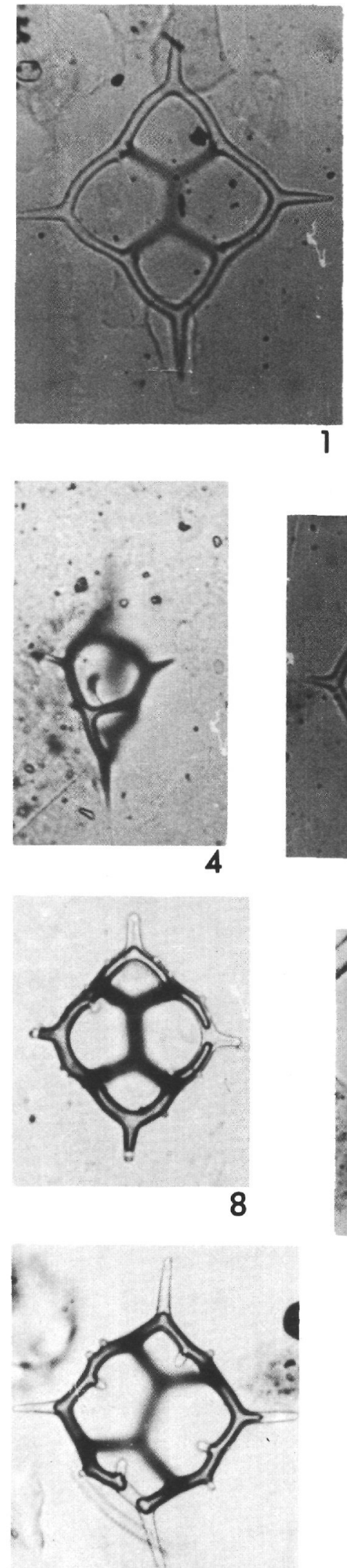

10
PLATE 4
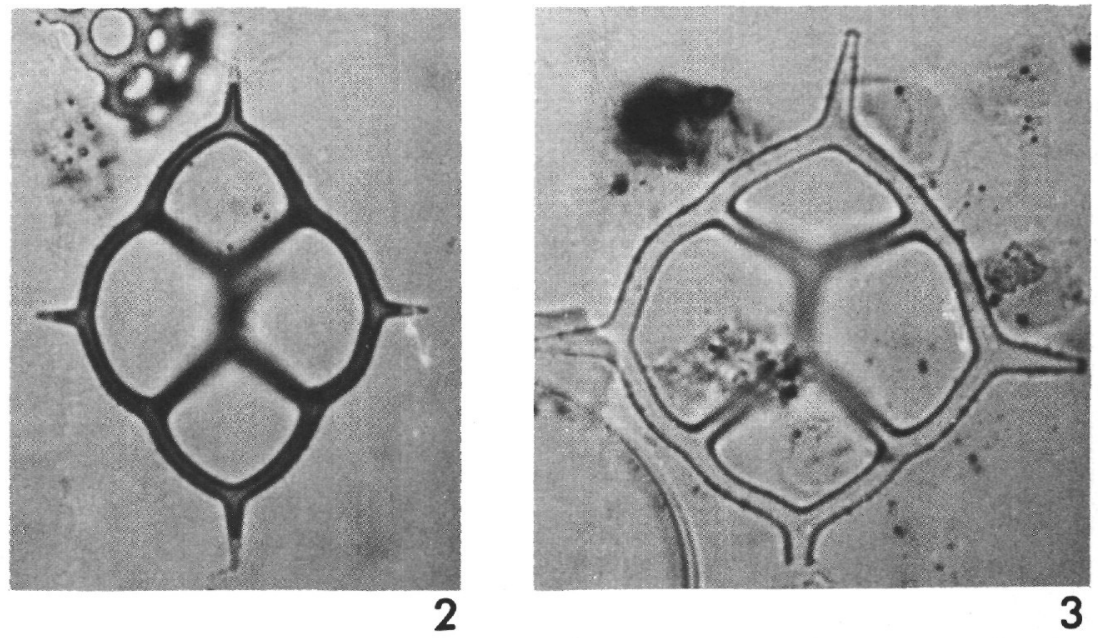

3
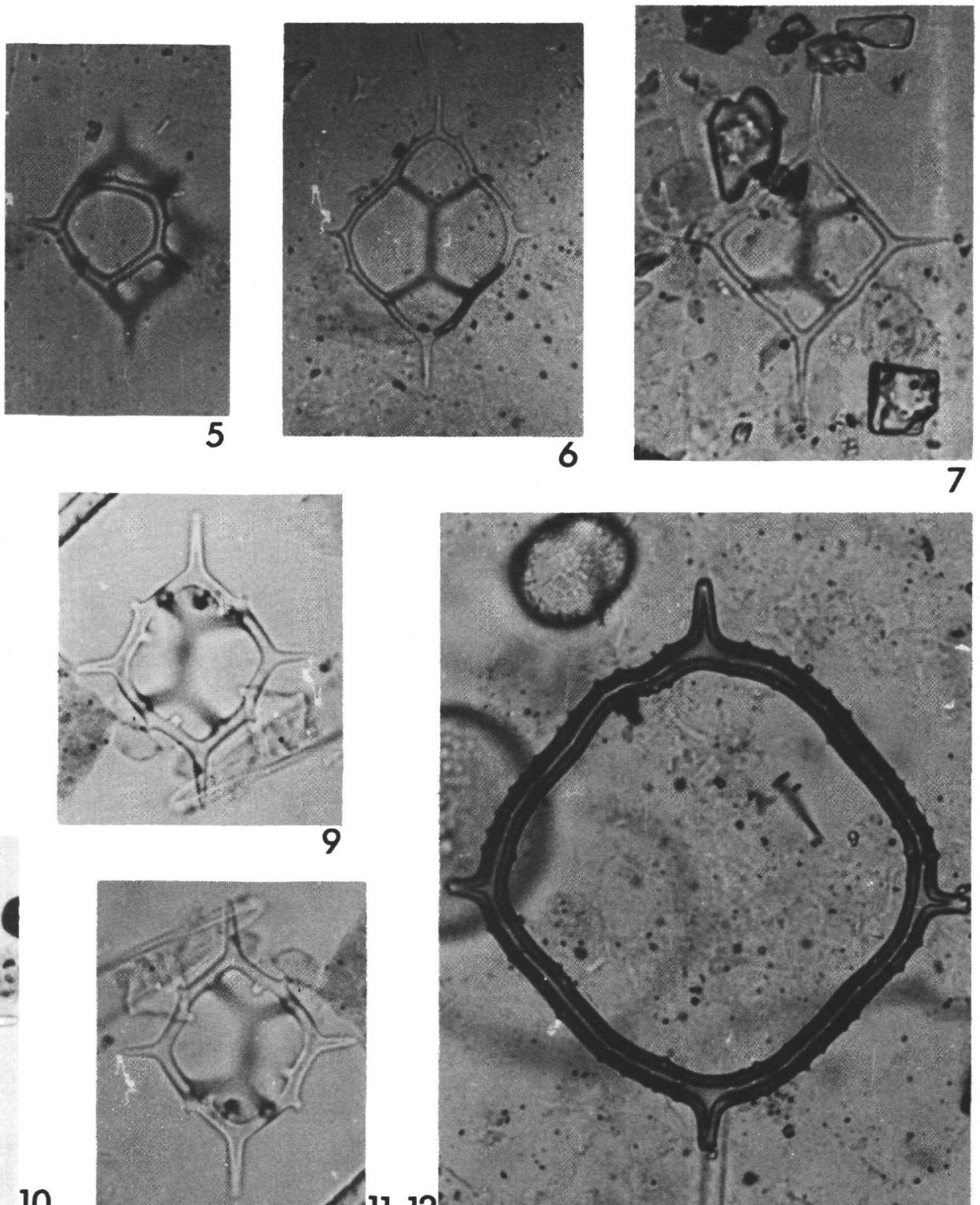

411 
PLATE 5

All figures $\times 570$

Figures 1-4 Dictyocha fibula Ehrenberg, various stages of mesocenoid forms, 206-18, CC.

Figures 5,6 Mesocena elliptica Ehrenberg. Figure 5, 206-37, CC; Figure 6, 205-4, CC.

Figure 7 Septamesocena apiculata (Schulz), 206-12, CC. 


\section{PLATE 5}
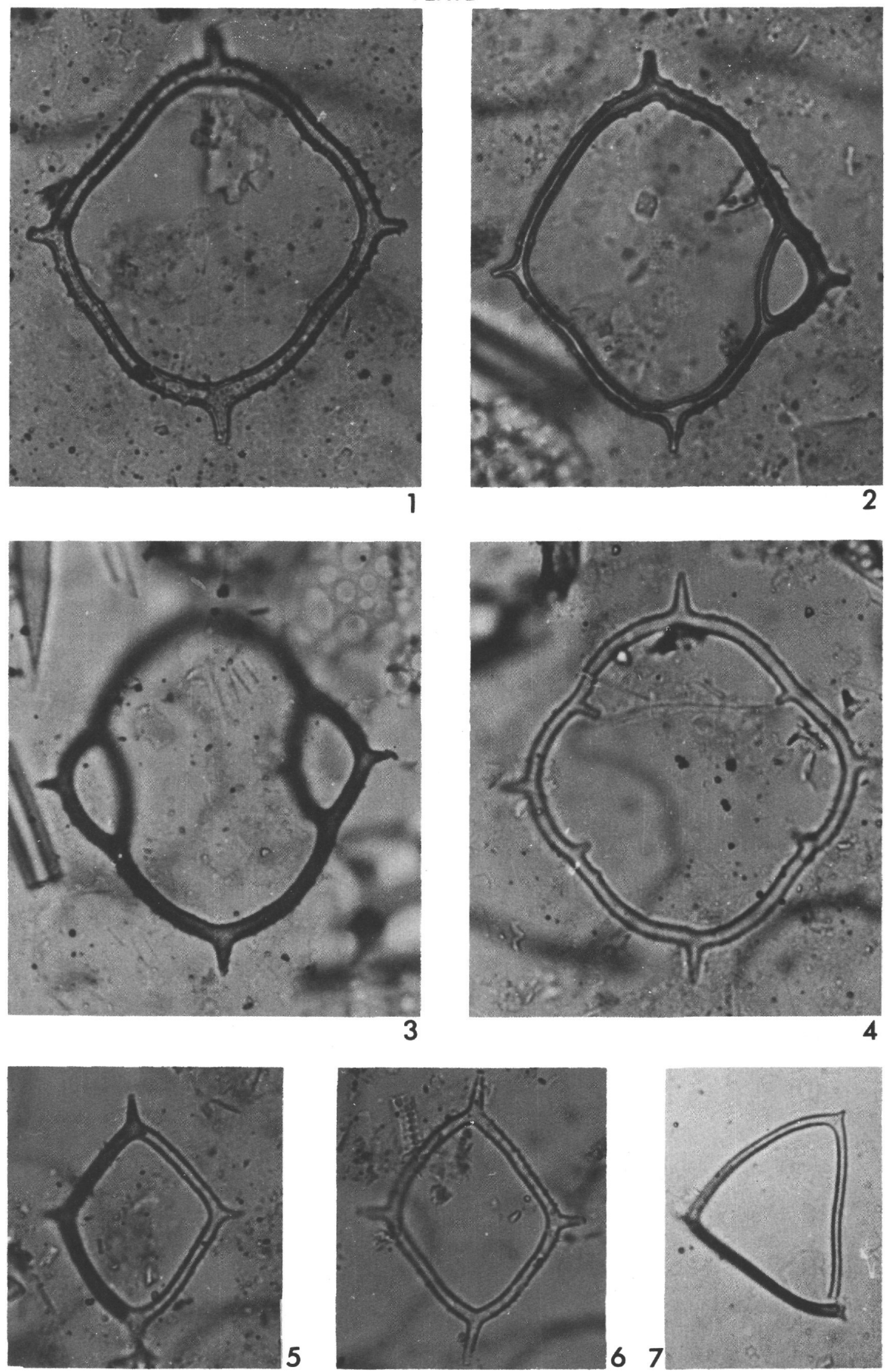


\section{PLATE 6}

All figures $\times 570$

Figure 1 “Mesocena" cf. elliptica Ehrenberg, 206-5, CC.

Figure 2 Mesocena diodon Ehrenberg, 206-27, CC.

Figures 3, 6,7 Distephanus crux spp. bispinosus n. ssp. Figures 3, 7, 206-20, CC; Figure 6, 206-18, CC.

Figures 4, 5, Distephanus crux (Ehrenberg). Figures 4, 5, 8, 8, $11 \quad 206-28$, CC; Figure 11, 205-5-1, 18-20 cm.

Figures 9, 10, Distephanus mesophthalmus (Ehrenberg). Figures 9, 12,13 12, 13, 206-27, CC; Figure 10, 206-26, CC.

Figures 14,15 Distephanus stauracanthus (Ehrenberg). Figure 14, normal form, 206-29, CC; Figure 15, dictyoid form, 206-30, CC. 
PLATE 6
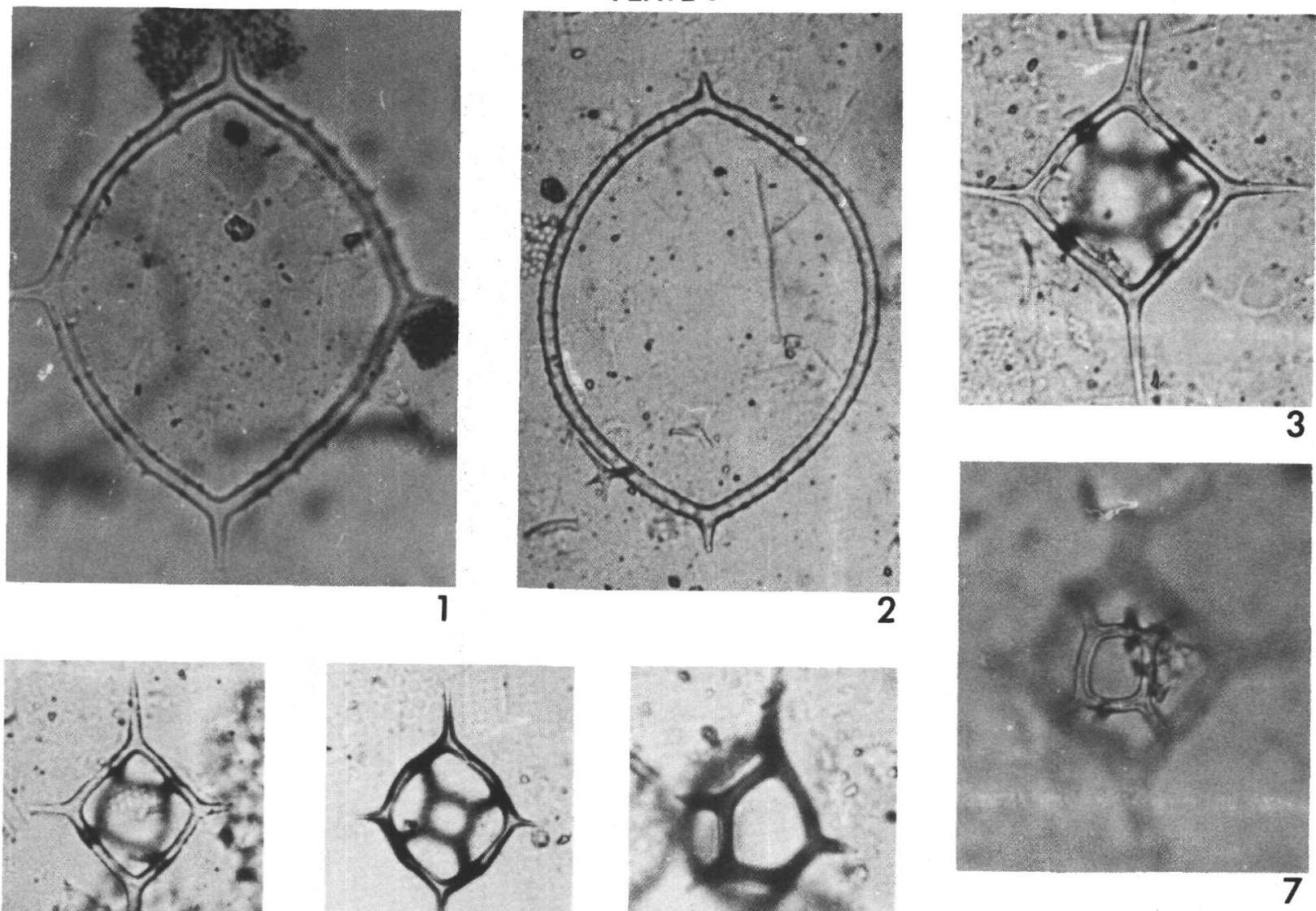
(*) 4
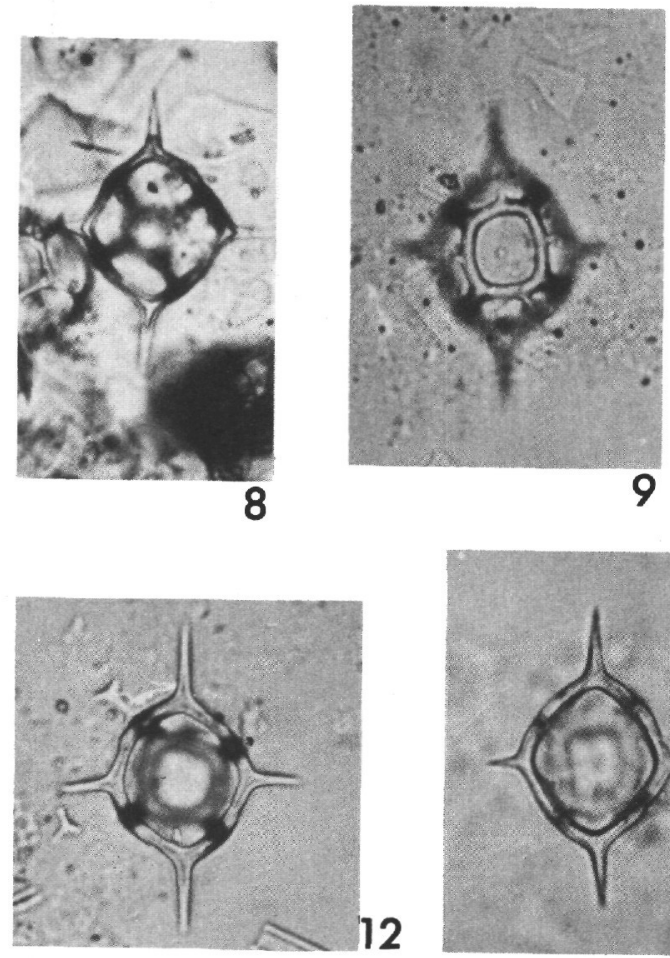
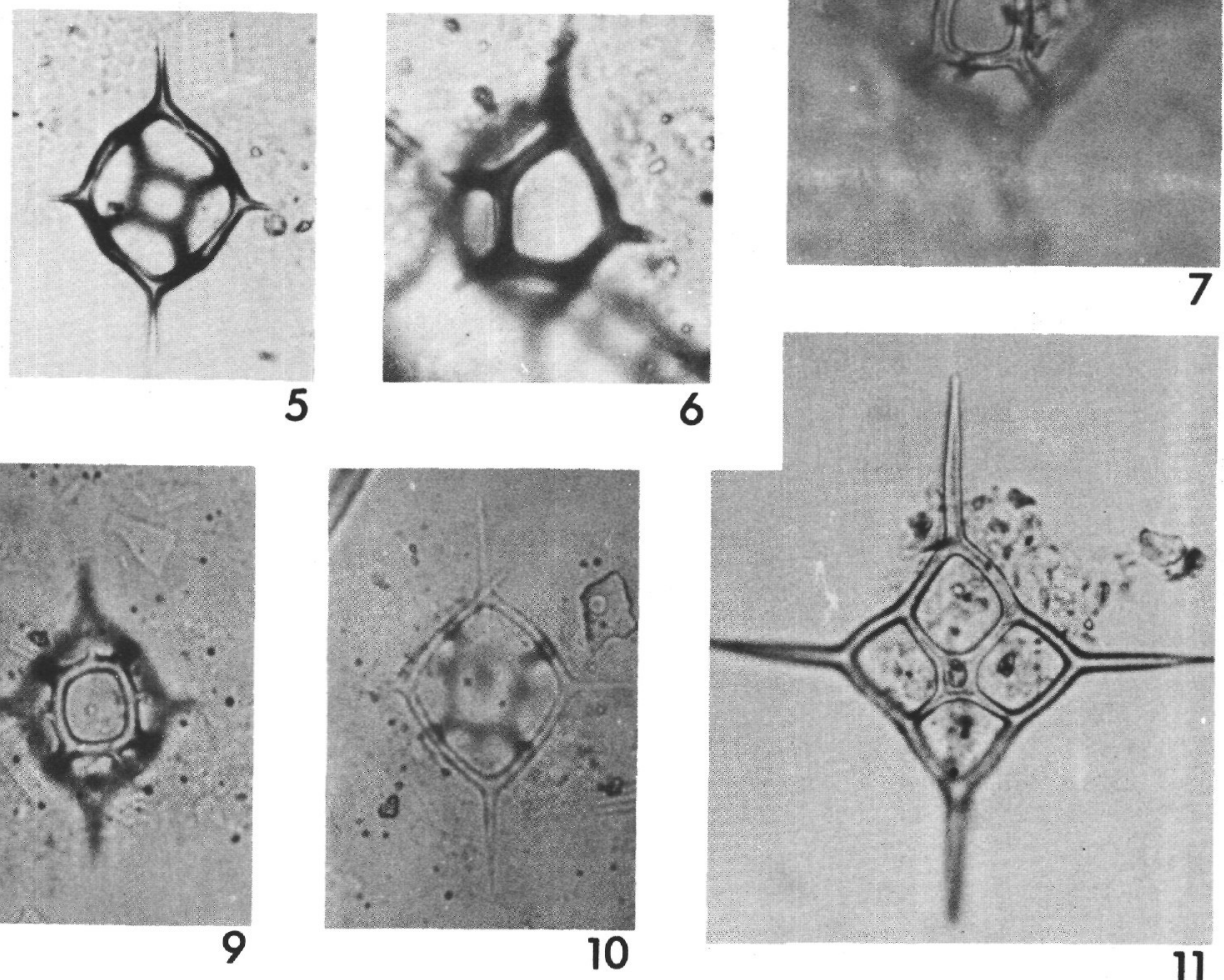

11
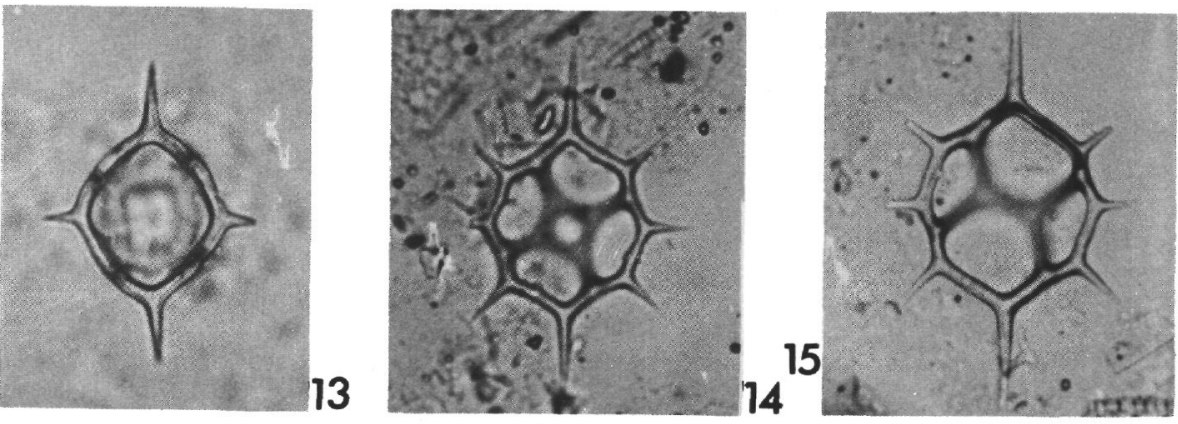
PLATE 7

All figures $\times 570$

Figures 1-4 Distephanus speculum (Ehrenberg) s.l., older forms lacking apical spines; Figure 1, pentagonal form, 206C-11, CC; Figures 2, 3, 206-31, CC; Figure 4, 206-32, CC.

Figures 5-9, 11 Distephanus speculum (Ehrenberg) s.l., younger forms. Figure 5, 206-14, CC; Figure 6, 206-4, CC; Figures 7, 8, 206-17, CC; Figure 9, 206-13, CC; Figure 11, 206-12, CC.

Figures 10, 12, Distephanus polyactis (Ehrenberg). Figure 10, $13205-5-1,18-20 \mathrm{~cm}$; Figure 12, 206-22, CC; Figure 13, 206-29, CC. 

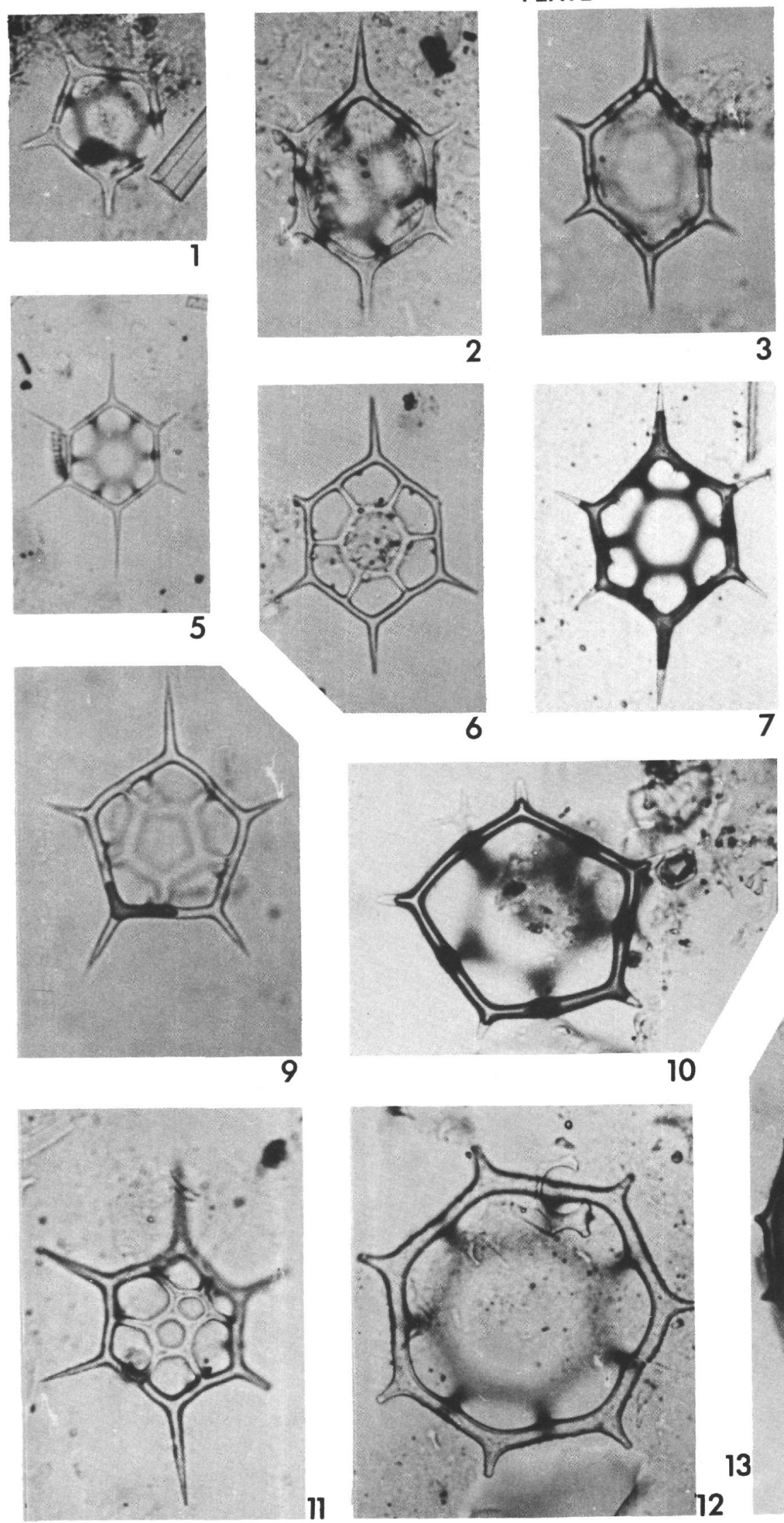

\section{PLATE 7}
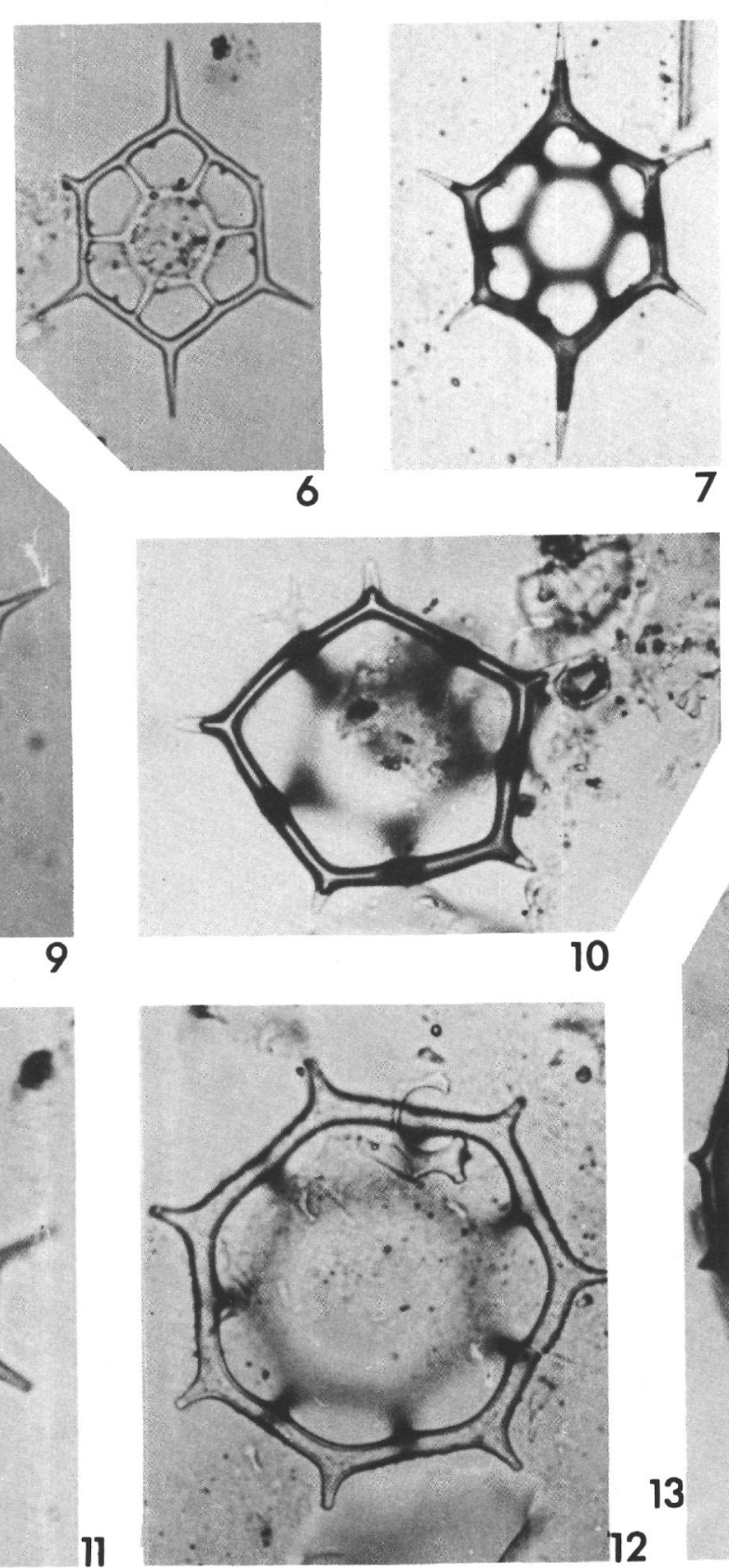

7
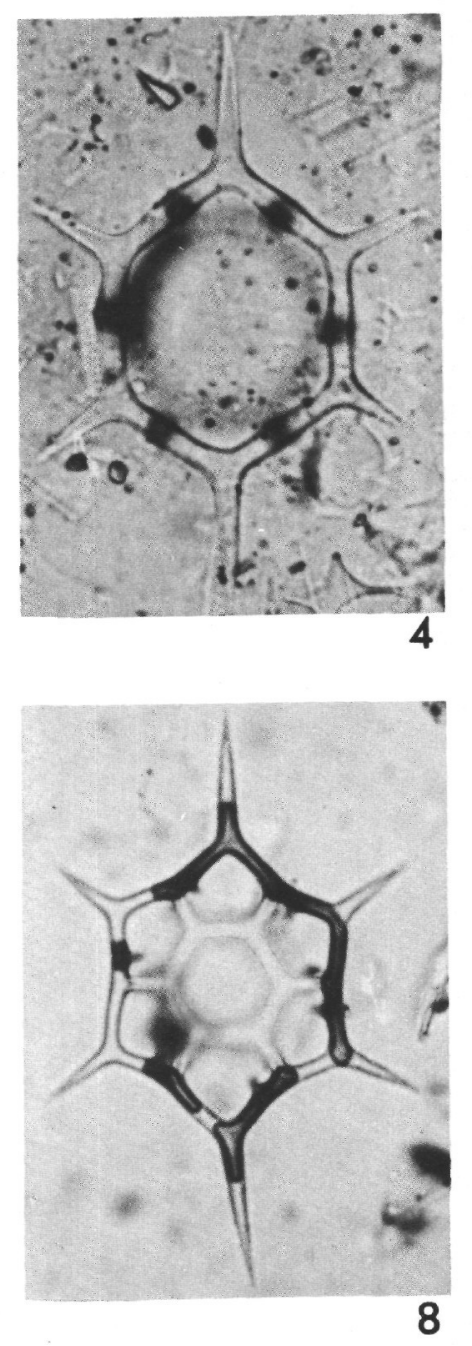

8

13

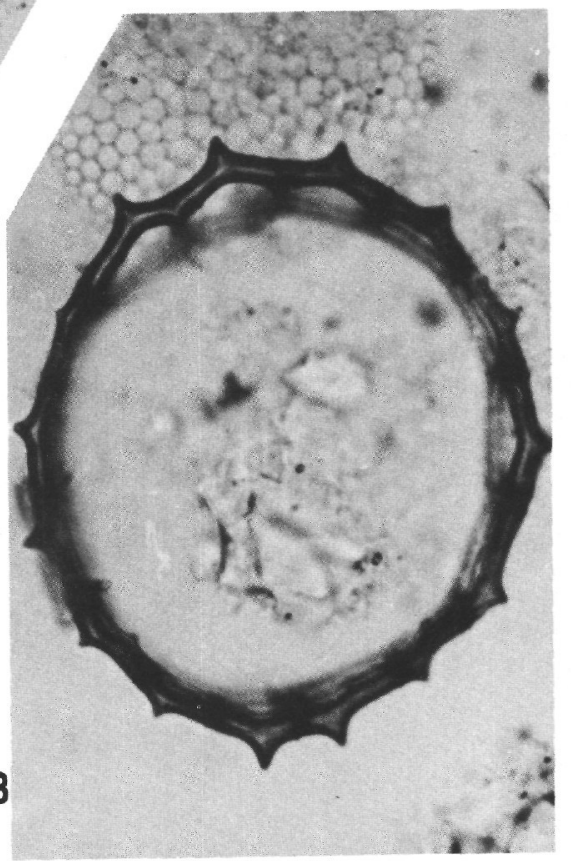




\section{PLATE 8}

All figures $\times 570$

\footnotetext{
Figures 1-10 Distephanus polyactis (Ehrenberg). Figures 1, 3, 206-29, CC; Figures 2, 8, 205-5-1, 18-20 cm; Figure 4, 206-30, CC; Figure 5, 206-28, CC; Figures 6, 7, 9, 206-25, CC; Figure 10, 206-22, CC.
} 
PLATE 8
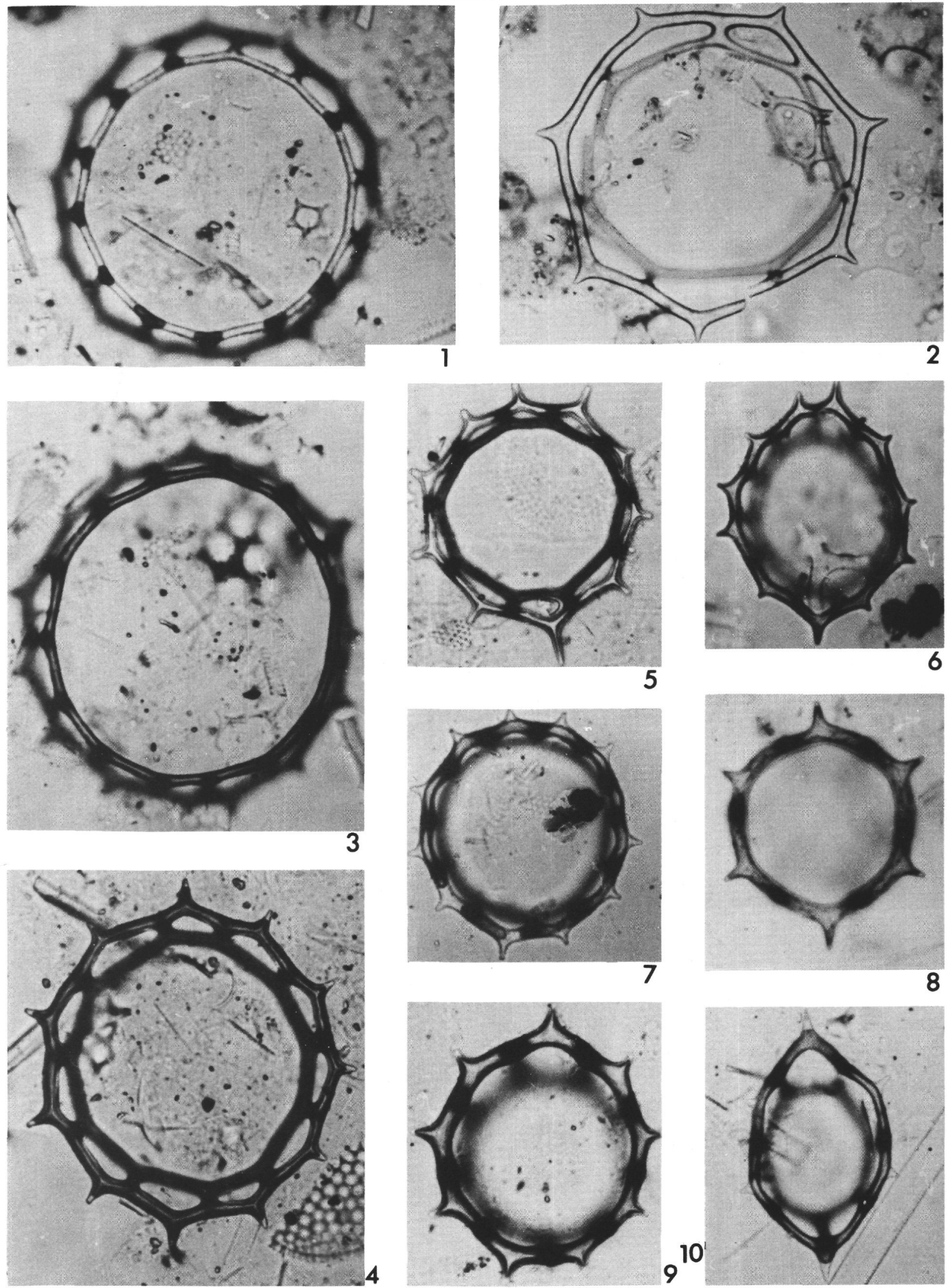
PLATE 9

All figures $\times 570$

Figures 1, 2 Distephanus polyactis (Ehrenberg). 206-22, CC.

Figures 3-6 Paradictyocha apiculata (Lemmermann). Figure 3, 206-22, CC; Figures 4-6, 206-30, CC.

Figures 7-10 Paradictyocha circulus (Ehrenberg). Figures 7, 8, 206-20, CC; Figure 9, 206-14, CC; Figure 10, 206-13, CC. 
PLATE 9
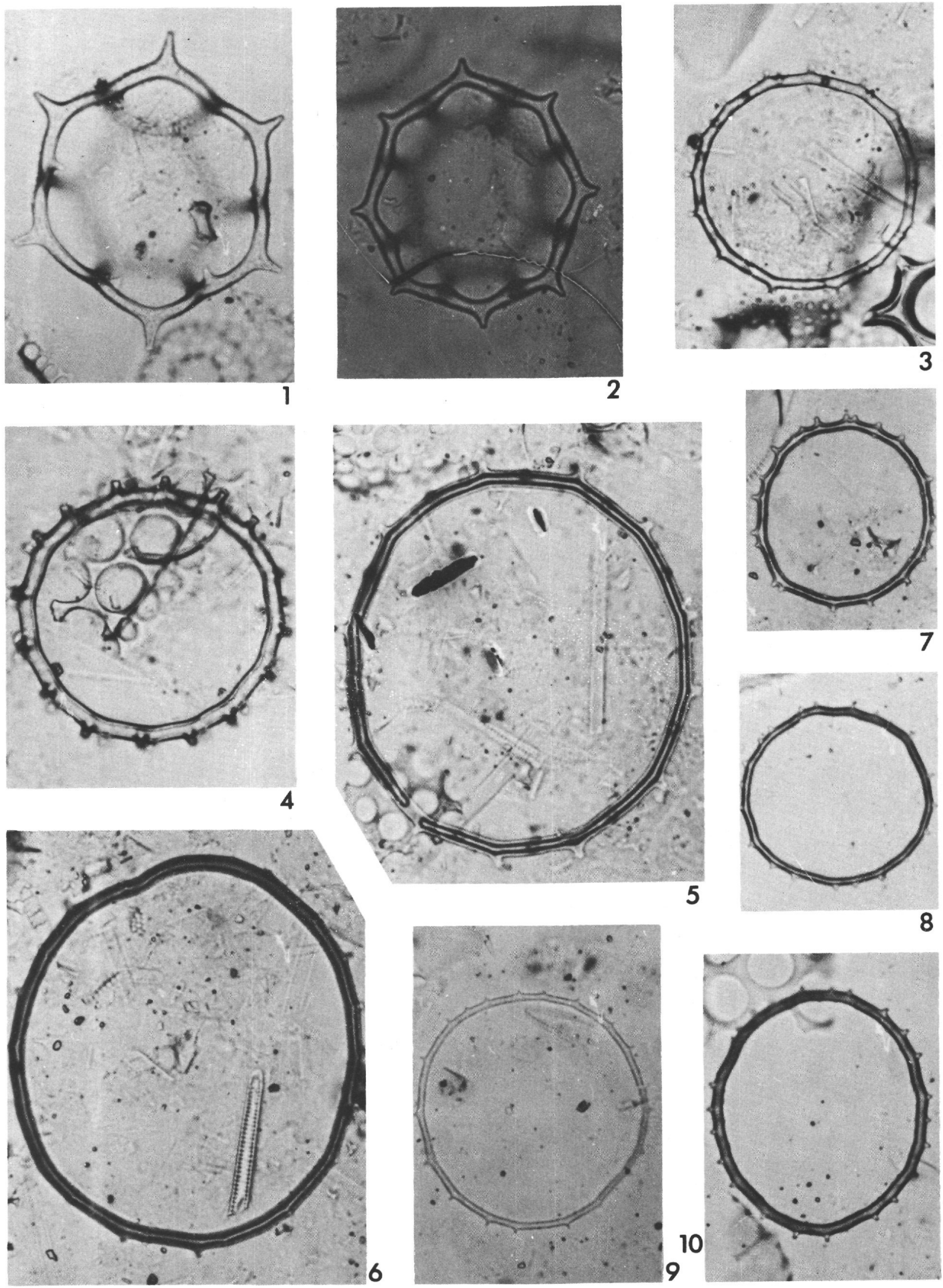


\section{PLATE 10}

All figures $\times 570$

Figures 1-4, 7 Distephanus ? heptacanthus (Ehrenberg). 206-14, CC.

Figure 5 Halicalyptra picassoi (Stradner), 206-31, CC.

Figure 6 Cannopilus hemisphaericus (Ehrenberg), 206-31, CC.

Figures 8-12 Cannopilus spp. Figures 8-11, forms probably referable to $C$. ernestinae Bachmann, 206-32, CC; Figures 8,9 , the same specimen focused on basal ring and on apical apparatus; Figures 10, 11, the same specimen focused on apical apparatus and on basal ring; Figure 12 , specimen probably referable to $C$. depressus (Ehrenberg), focused on basal ring, 206-31, CC. 

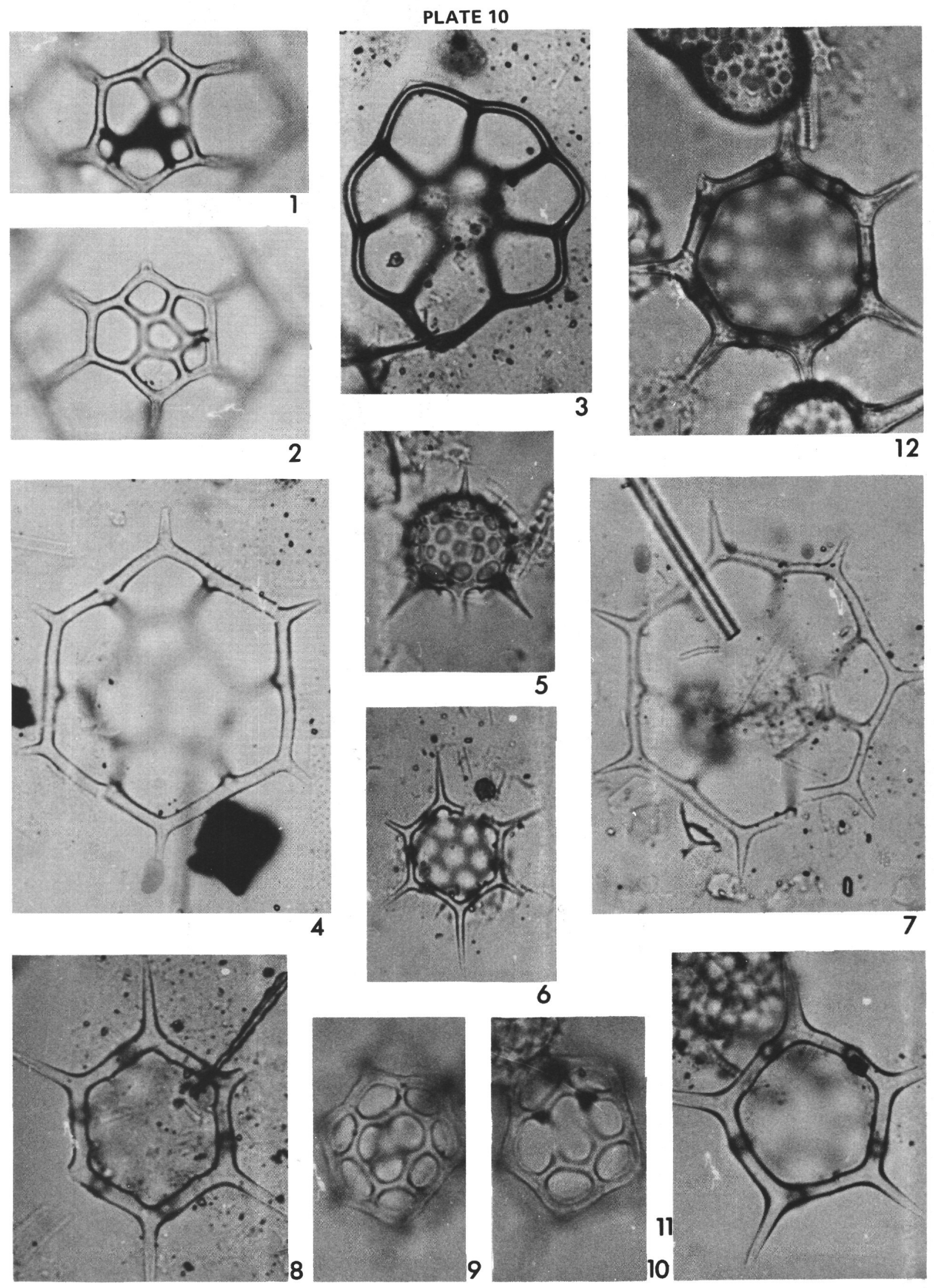
PLATE 11

All figures $\times 570$

Figures 1-5 Cannopilus spp. Figure 1, the specimen illustrated in Pl. 10, fig. 12, focused on apical apparatus, 206-31, CC; Figure 2, a specimen of the same type, focused on basal ring, 206-31, CC; Figures 3, 4, the same specimen focused on apical apparatus and on basal ring, 206-22, CC; Figure 5, a specimen in lateral view, 206:32, CC.

Figure 6 Distephanus ? heptacanthus (Ehrenberg), 206-14, CC.

Figures 7-12 Rocella gemma Hanna. Figure 7, 206-18, CC; Figures 8, 11, 12, 206-42, CC; Figure 9, 206-35, CC; Figure $10,206-45, \mathrm{CC}$. 


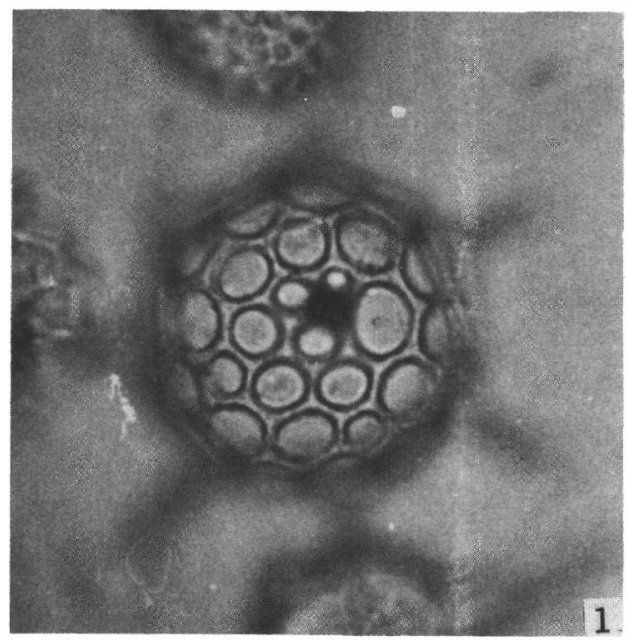

PLATE 11
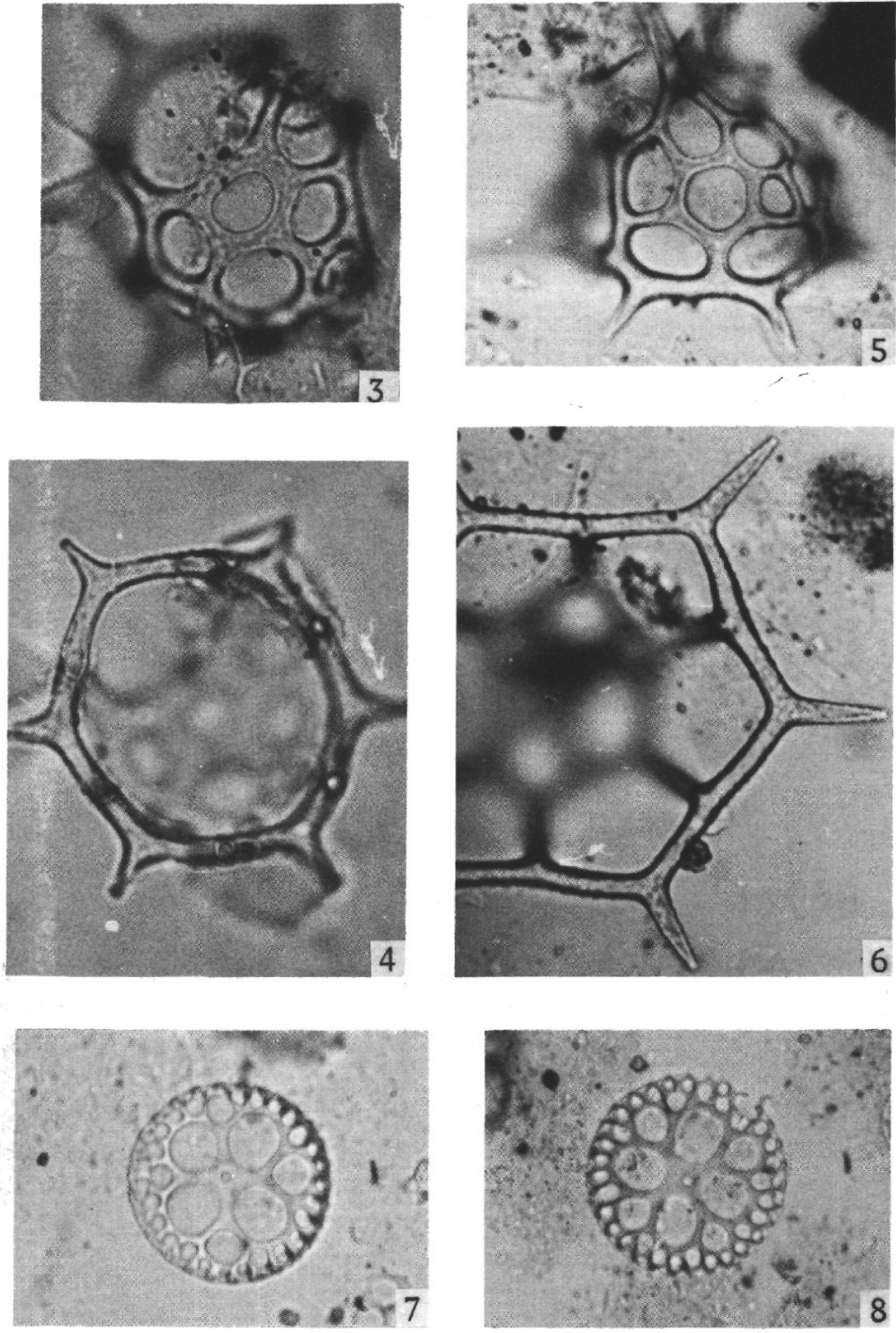
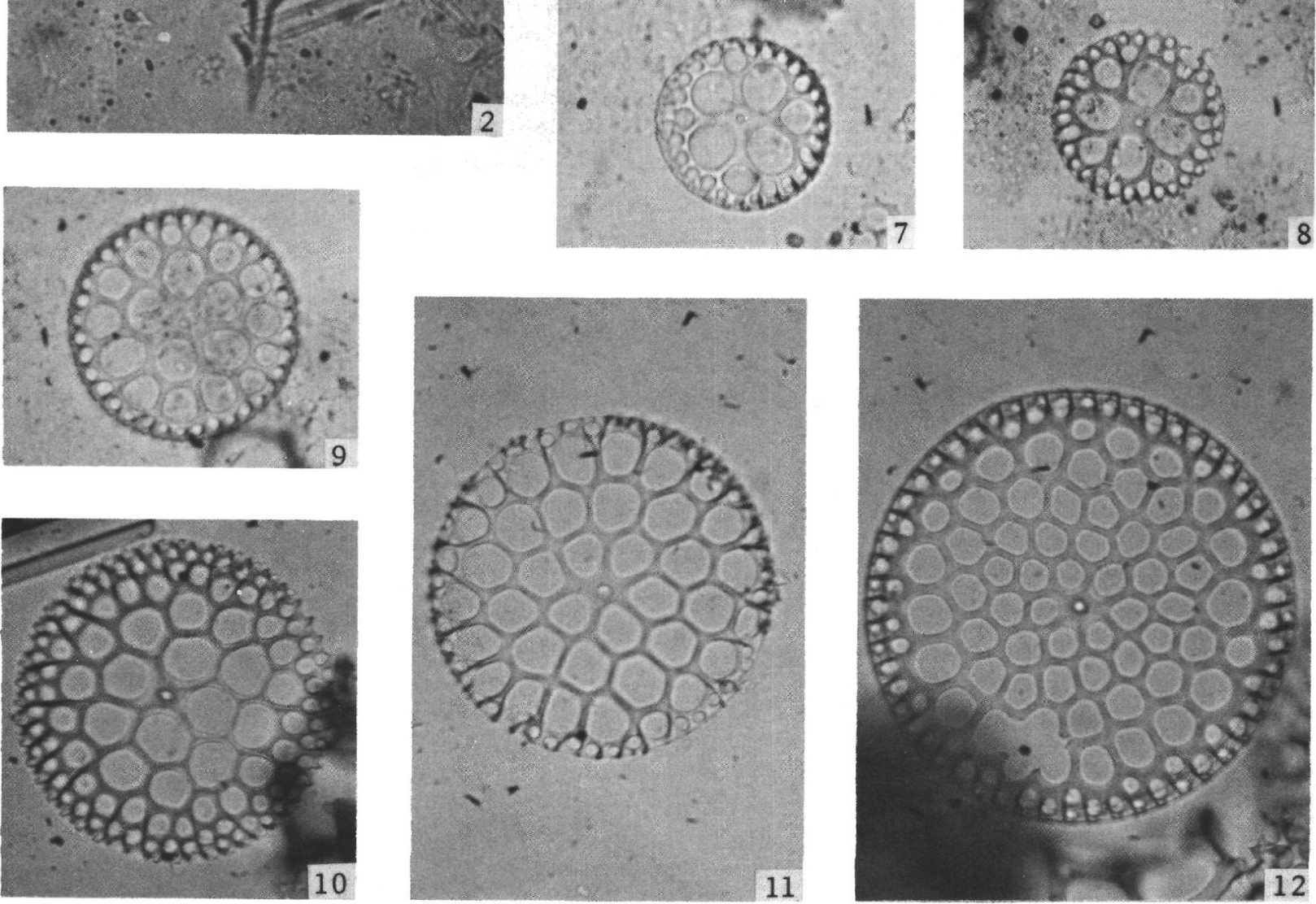
PLATE 12

All figures $\times 440$

Figures 1-6 Corbisema inermis ssp. disymmetrica n. ssp. 208-29, CC.

Figures 7-9 Corbisema inermis (Lemmermann), 208-31, CC. 


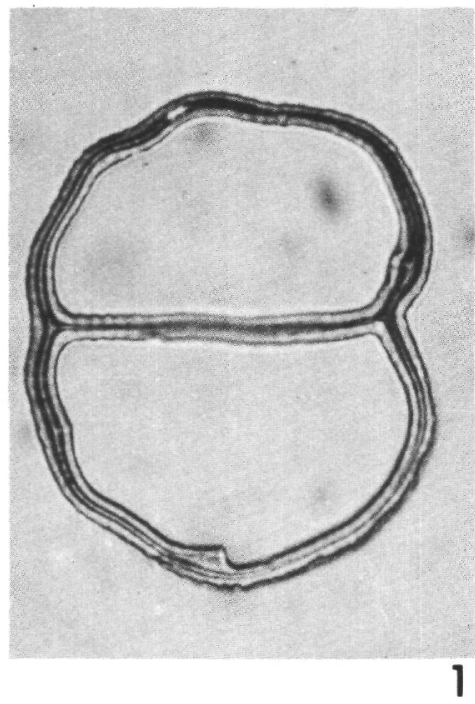

PLATE 12
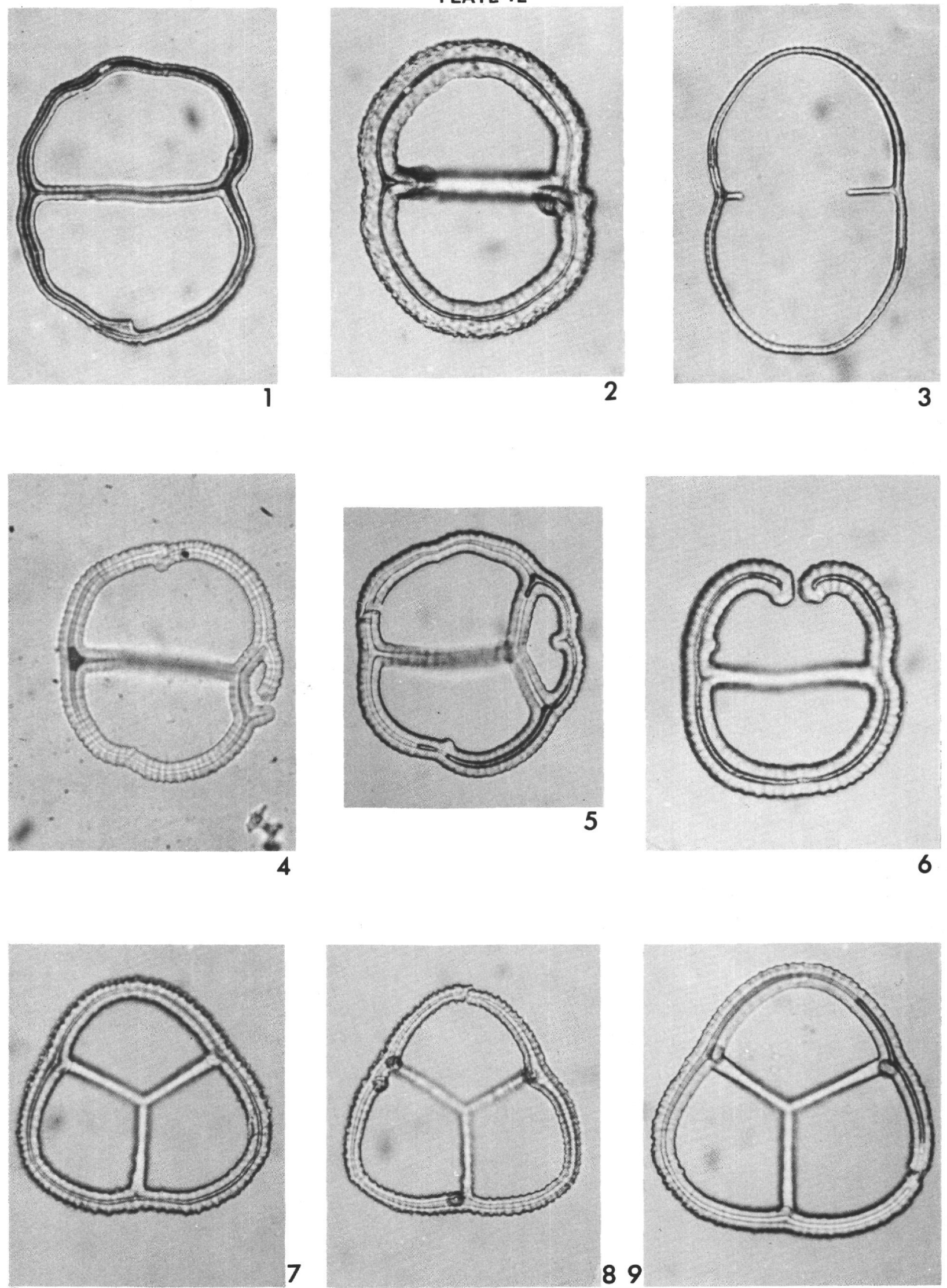


\section{P. DUMITRICÅ}

\section{PLATE 13}

Figures 1-3 X815; Figures 4-8 $\times 440$

Figures 1-8 Corbisema inermis ssp. disymmetrica n. ssp. 208-29, CC; Figure 3, view of the sustaining spine. 
PLATE 13
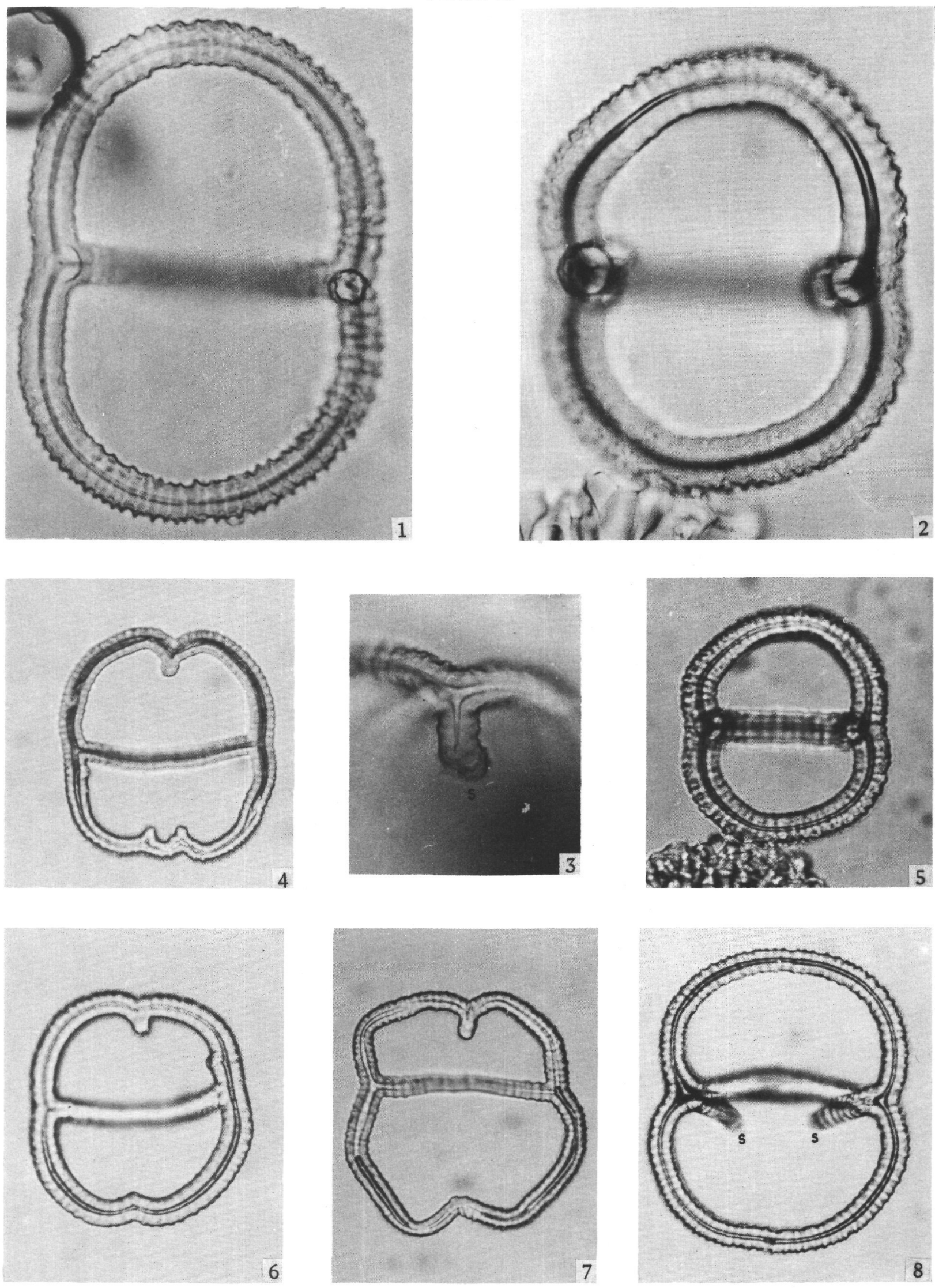